\title{
ZONEAMENTO AGROECOLÓGICO DA QUADRÍCULA DE RIBEIRÃO PRETO, SP, COM BASE EM CARACTERÍSTICAS DE SOLO, RELEVO E CLIMA
}

\section{LUCIETA GUERREIRO MARTORANO}

Meteorologista e Engenheiro Agrônomo

Orientador: Prof. Dr. LUIZ ROBERTO ANGELOCCI

Dissertação apresentada à Escola Superior de Agricultura "Luiz de Queiroz", Universidade de São Paulo, para obtenção do título de Mestre em Agronomia, Área de Concentração:

Agrometeorologia.

P I R A C I C A B A

Estado de São Paulo - Brasil

Abril - 1998 
Dados Internacionais de Catalogação na Publicação (CIP) DIVISÃO DE BIBLIOTECA E DOCUMENTAÇÃO - Campus "Luiz de Queiroz"/USP

Martorano, Lucieta Guerreiro

Zoneamento agroecológico da quadricula de Ribeirão Preto, SP, com base em caracteristicas de solo, relevo e clima / Lucieta Guerreiro Martorano. . Piracicaba, 1998.

77 p. : il.

Dissertação (mestrado) - Escola Superior de Agricultura Luiz de Queiroz, 1998. Bibliografia.

1. Clima 2. Geoprocessamento 3. Relevo 4. SIG (Sistema de computador) 5. Solo 6. Zoneamento agroecologico 1 . Título 
Obrigada,

Por mais esta oportunidade de crescimento.

As dificuldades ultrapassadas só foram possíveis devido a infinita bondade $\mathrm{e}$ constante ajuda. A vós meu Deus e ao meu mentor espiritual, este trabalho.

\section{OFEREÇO}

Aos meus amados pais, Francesco e Maria Herminia, pelos ensinamentos de força, coragem e constante apoio. Aos meus tios, Geraldo e Celeste, pelas orientações na minha adolescência. Aos meus manos Pedro e Antonieta, pela união e amor de nossa família. Ao meu tio Gabriel, pela força no inicio de minha carreira profissional e enfim, a todos os tios, primos, cunhados e sobrinhos. pelo carinho permanente e compreensão dos meus ideais. DEDICO 


\section{AGRADECIMENTOS}

Para a realização deste trabalho foi possível contar com a contribuição de professores e pesquisadores das áreas ligadas e este treinamento científico. A todos minha gratidão e registro as seguintes menções especiais:

Ao Professor Luiz Roberto Angelocci, meu orientador, pela postura amiga, valiosos ensinamentos, confiança e disponibilidade demonstradas no decorrer deste trabalho.

Ao Professor Carlos Alberto Vettorazzi, pela eficiente participação na definição da metodologia de pesquisa e pelas proveitosas críticas e sugestões apresentadas durante os trabalhos no Laboratório de Geoprocessamento.

Ao Professor, Valter Barbieri, pela valiosa contribuição no momento da seleção da área de trabalho e apoio durante a realização desta pesquisa.

Aos Professores Antonio Roberto Pereira, Nilson A. Villa Nova, Sérgio Moraes, Klaus Reichardt. Paulo C. Sentelhas e Paulo.L. Libardi, pelo apoio e colaboração durante o treinamento.

À Empresa Brasileira de Pesquisa Agropecúaria - EMPRAPA e ao Centro Nacional de Pesquisa de Solos - CNPS, por propiciarem a realização do Curso de Mestrado e pelo auxílio financeiro.

Ao Instituto Agronômico de Campinas pelo fornecimento dos dados meteorológicos de Ribeirão Preto.

Ao Departamento de Águas e Energia Elétrica pelo fornecimento dos dados dos postos pluviométricos utilizados neste trabalho. 
À empresa INTERSAT - IMAGENS DE SATÉLITE LTDA pelo fornecimento da imagem do LANDSAT-TM.

Ao Professor da UFBA Francisco A. Pereira, pelo apoio no tratamento dos dados, pela colaboração na análise dos resultados, e sobretudo, pelo apoio amigo nos momentos mais difíceis.

À estagiária Roberta de Oliveira A. Valente, pela prestimosa ajuda na fase de aprendizagem, digitalização, elaboração dos mapas no Sistema de Informações Geográficas - SIG IDRISI.

Aos colegas e amigos do curso Rosa Maria N. dos Santos, Zilda de Fátima Mariano, José Gabriel da Silva, Juan Rojas Delgado, Angélica Picini, Adriana Vieira de Camargo Moraes e Ricardo Pezzopane, pelo agradável convívio e estímulo.

À Professora Marina André de Alvarez pela colaboração na revisão do texto.

Aos colegas e grandes amigos Jeane Cruz Portela e Ivan André Alvarez, pelo incentivo e colaboração na fase final da dissertação.

À Escola Superior de Agricultura "Luiz de Queiroz", pela oportunidade de realização do curso.

Aos funcionários do Departamento de Física e Meteorologia Robinson Luís Tuon, Ana Maria da S. Maia Michelon, Fernando Novello, Vanderlino Assunção, Edivaldo Modesto de Abreu. Francisco Bernardo Dias pela acolhida e colaboração durante o curso.

Enfim, meu sincero apreço às demais pessoas que direta ou indiretamente contribuíram para o êxito desta dissertação. 


\section{ZONEAMENTO AGROECOLÓGICO DA QUADRÍCULA DE RIBEIRÃO PRETO, SP, COM BASE EM CARACTERÍSTICAS DE SOLO, RELEVO E CLIMA}

\section{LUCIETA GUERREIRO MARTORANO}

Aprovada em: 16. 06. 1998

Comissão julgadora:

Prof. Dr. LUIZ ROBERTO ANGELOCCI

ESALQ/USP

Prof. Dr. CARLOS ALBERTO VETTORAZZI

ESALQ/USP

Dr. ROGÉRIO REMO ALFONSI

IAC

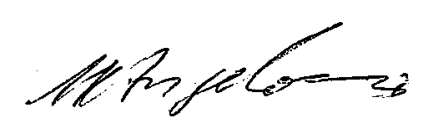

Prof. Dr. LUIZ ROBERTO ANGELOCCI

Orientador 
Página

LISTA DE FIGURAS

LISTA DE TABELAS ii

LISTA DE QUADROS iii

RESUMO iv

SUMARY v v

1 INTRODUÇÃO 1

2 REVISÃO DE LITERATURA 3

2.1 Zoneamento Agroecológico 3

2.2 Sistema de Informações Geográficos - SIG 7

3 MATERIAL E MÉTODOS

$\begin{array}{lll}3.1 & \text { Material } & 12\end{array}$

3.1.1 Localização da área de estudo 12

3.1.2 Características gerais da área de estudo 13

3.1.2.1 Geologia, relevo, vegetação, clima e uso atual da terra 13

$\begin{array}{ll}\text { 3.1.2.2 Solos } & 17\end{array}$

3.1.3 Dados meteorológicos $\quad 17$

3.1.4 Equipamentos $\quad 19$

$\begin{array}{ll}\text { 3.1.5 Softwares } & 19\end{array}$

3.2 Métodos 20

3.2.1 Solos 21

3.2.2 Relevo 23

$\begin{array}{ll}\text { 3.2.3 Clima } & 24\end{array}$

3.2.3.1 Temperatura do ar $\quad 24$

$\begin{array}{ll}\text { 3.2.3.2 Chuva } & 24\end{array}$

3.2.3.3 Balanço hídrico $\quad 26$ 
3.2.3.5 Cartas climáticas $27^{\vee}$

$\begin{array}{ll}\text { 3.2.3.6 Deficiência hídrica } & 27\end{array}$

$\begin{array}{ll}\text { 3.2.4 Zoneamento agroecologico } & 28\end{array}$

3.2.4.1 Critérios de avaliação da capacidade de uso das terras 28

3.2.4.2 Cruzamento das informações 32

4. RESULTADOS E DISCUSSÃO 34

$\begin{array}{ll}\text { 4.1 Solos } & 34\end{array}$

4.2 Relevo $\quad 35$

4.3 Clima $\quad 37$

4.3.1 Temperatura do ar : dados mensais e anuais 37

4.3.1.1 Temperaturas máximas e mínimas mensais 37

$\begin{array}{ll}\text { 4.3.1.2 Temperaturas médias } & 38\end{array}$

4.3.2 Temperatura do ar : dados diários de Ribeirão Preto 41

$\begin{array}{ll}\text { 4.3.3 Chuvas mensais e anuais } & 43\end{array}$

4.3.4 Chuvas: dados diários de Ribeirão Preto 45

4.3.4.1 Chuvas em qüinqüídios $\quad 45$

4.3.4.2 Chuvas máximas diárias $\quad 45$

4.3.5 Balanço hídrico $\quad 49$

4.3.6 Tipologia climática $\quad 52$

4.4 Zoneamento agroecológico

5. CONCLUSÕES

6. REFERÊNCIAS BIBLIOGRÁFICAS

$\begin{array}{lc}\text { ANEXOS } & 68\end{array}$ 


\section{LISTA DE FIGURAS}

Página

1 Representação dos Planos de Informações - PI's (Adaptado de Eastman, 10 1992)

2 Localização da área de trabalho

3 Exemplo de uso e ocupação do solo na área de estudo

4 Exemplo de um plantio de amendoim na área de estudo

5 Plantios de amendoim (primeiro plano) e cana-de-açúcar na área de estudo.

6 Fluxograma seqüencial da estrutura de obtenção, processamento e produto final dos dados analisados dentro do Sistema de Informações Geográficas.

7 Mapa de Solos da área de estudo

8 Mapa de Relevo da área de estudo

9 Média mensal das temperaturas máximas e mínimas na área de estudo.

10 Valores de temperatura média mensal na área de estudo.

11 Distribuição espacial das temperaturas médias na quadrícula

12 Distribuição espacial das temperaturas mínimas médias mensais na quadrícula

13 Distribuição espacial das chuvas médias anuais, na área de estudo

14 Chuvas máximas em 24 horas em cada mês, ocorridas no período de 1967 a 1996 em Ribeirão Preto, SP.

15 Mapa de deficiência hídrica anual da região de Ribeirão Preto, SP.

16 Mapa de tipologia climática segundo Thornthwaite (1948)

17 Mapa de Zoneamento Agroecológico da quadrícula de Ribeirão Preto, SP 


\section{LISTA DE TABELAS}

Página

1 Classes de Latossolos, área e percentual de ocorrência na quadrícula de Ribeirão Preto.

2 Zonas agroecológicas, número de classes correspondentes a solo, relevo e 32 deficiência hídrica .

3 Classes de amplitude altimétrica (m) e suas respectivas áreas.

4 Frequiência ( $\mathrm{f}$ ) e probabilidade $\mathrm{P}(\mathrm{x})$ em porcentagem de ocorrência de chuvas máximas em 24 horas, igual ou menor do que o valor médio (PM), em Ribeirão Preto, SP.

5 Valores anuais, em milímetros, de Evapotranspiração Potencial - EP, 49 Precipitação pluvial - P, Evapotranspiração Real - ER, Deficiência Hídrica DEF, Excedente Hídrico - EXC.

6 Zonas agroecológicas e suas respectivas áreas e percentagens, na quadrícula de Ribeirão Preto, SP. 


\section{LISTA DE QUADROS}

Página

1 Identificação das 22 estações meteorológicas.

2 Valores médios de altura pluviométrica mensal e anual, referentes as localidades situadas na quadrícula e localidades vizinha.

3 Freqüências de chuvas por qüinqüídios, no verão e outono, em Ribeirão Preto, SP.

4 Freqüências de chuvas por qüinqüídios, no inverno e primavera, em Ribeirão Preto, SP.

5 Valores de deficiências hídricas anuais comparados aos graus de limitaçào desses fatores adotados por Ramalho Filho (1995). 


\title{
ZONEAMENTO AGROECOLÓGICO DA QUADRÍCULA DE RIBEIRÃO PRETO, SP, COM BASE EM CARACTERÍSTICAS DE SOLO, RELEVO E CLIMA
}

\author{
Autora: LUCIETA GUERREIRO MARTORANO \\ Orientador: Prof. Dr. LUIZ ROBERTO ANGELOCCI
}

\section{RESUMO}

Considerando-se que o Estado de São Paulo representa um pólo de expansão agro-industrial e tendo por objetivo contribuir com a metodologia de identificação de potencialidades de uso das terras, o presente trabalho apresenta uma proposta de zoneamento agroecológico da quadrícula de Ribeirão Preto, com base em características de solo, relevo e clima, em ambiente SIG, visando a subsidiar estudos que possibilitem estimar a capacidade de suporte do ambiente aos impactos devido à ocupação humana. A área situa-se entre as coordenadas geográficas de $21^{\circ} 00^{\prime} \mathrm{S}$ a $21^{\circ} 30^{\prime} \mathrm{S}$ e $47^{\circ} 30^{\prime} \mathrm{W}$ a $48^{\circ}$ $00^{\prime} \mathrm{W}$, localizada na parte NE do Estado de São Paulo, cobrindo uma área de 287.057,5 hectares e abrange 15 municípios. A quadrícula foi selecionada em função da sua importância sócio-econômica, bem como da disponibilidade de informações existentes, dentre elas: carta de solos em nível de semidetalhe, carta topográfica e dados meteorológicos. Utilizou-se dados de temperatura do ar e chuva, referentes ao período de 1967 a 1996 de 22 localidades para caracterizar o regime térmico-hídrico da área. 
Elaborou-se um conjunto de critérios quanto a capacidade de uso, baseados, primordialmente, nas combinações do efeito do clima, relevo e características permanentes do solo, que limitam o uso agricola e/ou impõem riscos de degradação pela erosão acelerada. O zoneamento identificou seis unidades de utilização da terra denominadas de: agricultura (I); agricultura (II); agricultura (III); pecuária; agrossilvicultura e preservação. Na quadrícula de Ribeirão Preto, SP, conclui-se que: existe uma relativa uniformidade climática na área de estudo, evidenciados pelos valores termico-hídricos médios; os fatores determinantes para a indicação de zonas agroecológicas destinadas à preservação e agrossilvicultura os relacionados quanto ao solo e ao relevo; as zonas agroecológicas apresentadas em nível macro, produtos de uma proposta metodológica na identificação de potencialidades de uso da terra, evidenciaram que $82,5 \%$ das terras na quadrícula possuem vocação para uso com agropecuária e $10,4 \%$ devem ser preservadas ou utilizadas seguindo orientações conservacionistas; a quadrícula possui vocação dominante para agricultura intensiva, denominada de agricultura (I), observando-se na porção noroeste da quadrícula que o uso atual, em sua maior parte, vem obedecendo a vocação agrícola daquela terras; a utilização do recurso solo, na porção nordeste e sudeste com pecuária, sem levar em consideração as suas verdadeiras limitações, poderá trazer conseqüências aos ecossistemas frágeis indicados pelo zoneamento para agrossilvicultura e preservação. Verificou-se a importância e a operacionalidade do SIG, como ferramenta metodológica para realizar a integração de varáveis ambientais de forma hierarquizada dos mapas temáticos. 


\section{AGROECOLOGICAL ZONING OF RIBEIRÃO PRETO'S QUADRANGLE, SP, BASED ON SOIL CHARACTERISTICS, RELIEF AND CLIMATE}

Author: LUCIETA GUERREIRO MARTORANO

Advisor: Prof. Dr. LUIZ ROBERTO ANGELOCCI

SUMMARY

Being considered that the State of São Paulo represents a pole of agriculture and industrial expansion with the objective to contribute with the methodology of identification of land use potentialities, this work presents a proposal of agroecological zoning of the quadrangle of Ribeirão Preto, based on soil characteristics, relief and climate, in a SIG environment, seeking to subsidize studies that facilitate to estimate the support capacity of the environment to the impacts due to the human occupation. The study area is located among the geographical coordinates of $21^{\circ} 00^{\prime} \mathrm{S}$ at $21^{\circ} 30^{\prime} \mathrm{S}$ and $47^{\circ} 30^{\prime} \mathrm{W}$ to $48^{\circ} 00^{\prime} \mathrm{W}$, in the NE portion of the State of São Paulo, covering an area of $287.057,5$ hectares and it embraces 15 municipal districts. The quadrangle was selected in function of its socioeconomic importance, as well as of the readiness of existent 
information, as: map of soils in semidetail level, topographic map and meteorological data. It was used data of temperature of the air and rain, referring to the period of 1967 to 1996, of 22 places to characterize the thermic-hydric regime of the area. A group of criteria was elaborated regarding the use capacity, set, based, primarily, in the combinations of the effect of the climate, relief and permanent characteristics of the soil, that limit the agricultural use and/or imposes degradation risks due to the accelerated erosion. The zoning identified six units of land use: agriculture (I); agriculture (II); agriculture (III); pecuária; agroforest systems and preservation. For the quadrangle of Ribeirão Preto, SP, it was concluded that: a relative climatic uniformity exists in the study area, evidenced by the average thermic-hydric values; the decisive factors for the indication of agroecological zones destined to the preservation and agroforest systems were the ones the related to the soil and the relief; the agroecological zones presented in macro-level, products of a methodological proposal in the identification of potentialities of land use, evidenced that $82,5 \%$ of the lands in the quadrangle possess vocation for use with agriculture and $10,4 \%$ should be preserved or used according to conservation orientations; the quadrangle presents dominant vocation for intensive agriculture, denominated of agriculture (I), being observed in the northwestern portion of the quadrangle the current use. in its largest part, agrees with obeying the agricultural vocation of that lands; the use of the resource soil, in the northeastern and southeastern portions with cattle raising, without taking in consideration its true limitations, can bring consequences to the fragile ecosystems indicated by the zoning for agroforest system and preservation. It was verified the importance and the functionality of GIS, as a methodological tool to accomplish the integration of environmental variables in hierarchyc way of the thematic maps. 


\section{INTRODUÇÃO}

A política de desenvolvimento, com visão de futuro, deve estar voltada às preocupações que contemplam também aspectos nas vertentes social e ambiental. O uso permanente de paisagens produtivas impõe cada vez mais a necessidade de caracterização prévia das limitações ambientais, para ocupação ordenada do espaço territorial.

No momento da implantação de novos empreendimentos e na manutenção de projetos em desenvolvimento, torna-se de grande valia a obtenção de dados e informações a respeito dos recursos naturais e das condições sócio-econômicas, pois permitem a seleção de áreas com maior potencialidade de uso, indicando as atividades mais apropriadas a uma região com conservação e preservação ambientais.

O Estado de São Paulo oferece condições vantajosas no tocante à localização, solos, clima. infra-estrutura. padrão agrícola e produção orientada em bases econômicas (DAEE, 1973). No entanto, em vista do intenso processo de urbanização e ocupação da maioria das terras agricultáveis, há necessidade de fornecer dados atualizados que possibilitem orientar a política de desenvolvimento regional (Alfonsi et al., 1995).

Apesar da existência de um zoneamento agrícola para o Estado (Camargo et al., 1974), torna-se necessário a retomada de novos trabalhos nesta linha, no sentido de aprimorar o zoneamento, levando-se em consideração a dinâmica de informações necessárias à adequação de técnicas de monitoramento ambiental (Alfonsi et al., 1995). 
Novas tendências surgiram nas décadas de 60 e 70 , objetivando apresentar informações mapeadas na avaliação das terras e seu planejamento. Passou-se a analisar os diferentes aspectos da natureza de forma integrada e interdisciplinar, criando-se os primeiros programas de computador para esse fim, os chamados Sistemas de Informações Geográficas - SIG's, com grande vantagem de trabalhar em ambientes tão diversos como os computadores pessoais e as estações de trabalho (workstations).

$\mathrm{Na}$ atualidade, a popularização do uso de microcomputadores, promoveu uma crescente difusão dos SIG's, surgindo no mercado "pacotes" computacionais que possibilitam a sua utilização nas mais diversas atividades, como: cartografia, sensoriamento remoto, gerenciamento ambiental, planejamento urbano e estudos envolvendo a exploração e preservação dos recursos naturais (Ferraz, 1996).

Considerando-se que o Estado de São Paulo representa um pólo de expansão agro-industrial e tendo por objetivo contribuir com a metodologia de identificação de potencialidades de uso das terras, o presente trabalho apresenta uma proposta de zoneamento agroecológico da quadrícula de Ribeirão Preto, com base em características de solo, relevo e clima, em ambiente SIG, visando subsidiar estudos que possibilitem estimar a capacidade de suporte do ambiente aos impactos devidos à ocupação humana. 


\section{REVISÃO DE LITERATURA}

\subsection{Zoneamento Agroecológico}

Os estudos voltados à indicação de áreas compatíveis com as suas vocações vêm crescendo, substancialmente, nos últimos anos. Entende-se por vocação o conjunto de facilidades naturais de uma região para produzir alimentos e outros produtos agrícolas, relacionadas principalmente ao clima, solo, água, mão-de-obra, distância ao mercado consumidor e extensão territorial (AGRIANUAL 97, 1996). Acredita-se que a vocação agrícola regional seja a carta mais valiosa na adequação do uso da terra.

É notório salientar que a produção agrícola necessita, como qualquer outra atividade, de um planejamento calcado nas informações disponíveis, otimizando o manejo do meio físico, buscando minorar os impactos causados pela ação antrópica sobre o ambiente (Oliveira Junior, 1994).

Para evitar ou minimizar conseqüências danosas, tem-se com o zoneamento agroecológico um tipo de ordenamento que caracteriza ofertas, limitações biofísicas e espaciais para ocupação harmônica do homem às diversas paisagens produtivas de um território (Sánchez, 1989). No Brasil, as áreas para atividades agrícolas, florestas comerciais, recreação, preservação e outras atividades devem ser selecionadas em função de suas vocações e adequabilidades aos respectivos usos (Palmieri \& Larach, 1996).

A adoção de procedimentos como preparo de boletins e mapas de solos tem servido para facilitar pesquisas quanto a produção agrícola, zoneamento das terras e assentamento humano (Brady, 1989). Com essa visão, muitos estudos de zoneamento já foram desenvolvidos no Brasil, buscando o ordenamento do espaço territorial. 
Considera-se zoneamento a destinação factual ou jurídica da terra às diversas modalidades de uso humano (Moreira Neto, 1976). O zoneamento ambiental define-se como sendo a integração sistemática e interdisciplinar da análise ambiental ao planejamento de uso dos solos, visando à melhor gestão dos recursos ambientais identificados (FEEMA, 1980).

Nos programas de desenvolvimento agro-industrial, existe grande necessidade de se obter a carta de aptidão ecológica das culturas envolvidas, condicionada pelos fatores físicos como o solo e o clima. Das propriedades do solo, os aspectos físicos são os que apresentam menor variabilidade, com relação às condições climáticas, estas apresentam poucas variações em uma região, em se tratando do estado médio da atmosfera. Somando os dois fatores, climático e edáfico, tem-se o fator ecológico geral que indica a potencialidade da região (Camargo, 1971).

A estrutura dos solos tende a funcionar como o maior organizador de ecossistemas terrestres. Em sistemas agrícolas, o manejo é o principal agente de perturbações no solo e modificações adversas a sua estrutura. Do ponto de vista ecológico, tais perturbações influenciam fortemente na distribuição de substâncias orgânicas ricas em energia e o conseqüente impacto sobre o fluxo energético e a dinâmica dos ciclos geoquímicos no solo. $\mathrm{O}$ manejo pode causar queda excessiva dos principais agentes de agregação, desencadeando, por exemplo, o processo erosivo das terras. Logo ele é um componente do sistema que pode influenciar tanto negativa quanto positivamente na sustentabilidade agrícola (Castro, 1980).

O Brasil perde, por erosão laminar, quinhentos milhões de toneladas de terra anualmente, o que corresponde a um desgaste uniforme de uma camada de $15 \mathrm{~cm}$ numa área de cerca de 280.000 hectares, constituindo, sem dúvida, a principal causa de depauperamento acelerado das terras. A erosão não é a mesma em todos os solos, ela depende das propriedades fisicas, principalmente estrutura, textura, permeabilidade e densidade global, assim como as características químicas e biológicas do solo (Bertoni \& Lombardi Neto, 1990). Tomando como exemplo as Areias Quartzosas, apesar de 
apresentarem boa permeabilidade, não possuem coesão entre as partículas, os que as tornam de grande suscetibilidade à erosão (Venturim \& Bahia, 1998).

Do ponto de vista pedológico, os solos possuem características diferentes, mas com relação à importância agronômica, eles podem ser classificadas de acordo com o tipo de manejo por classes de aptidão agrícola (Oliveira, 1980). A capacidade de suporte dos solos avalia-se pela determinação da aptidão agrícola das terras (Ramalho Filho et al., 1995). A classificação dessa aptidão constitui um método com base em critérios científicos, para orientação quanto ao uso dos recursos pedológicos, de forma racional e otimizada, em nível de planejamento regional e nacional (Formaggio et al., 1992). Por outro lado, a classificação da capacidade de uso do solo visa estabelecer bases para seu melhor aproveitamento e permite avaliar as necessidades dos diferentes tipos de uso (Bertoni \& Lombardi Neto, 1990).

Sob o ponto de vista climático, o zoneamento propicia a seleção de áreas mais apropriadas a determinada cultura, onde os riscos impostos pelo clima são menores, permitindo ao agricultor trabalhar com maior chance de acerto (AGRIANUAL-97, 1996). Camargo (1971) enfatiza que após o conhecimento das possibilidades e limitações ecológicas de uma cultura, espera-se um melhor aproveitamento de seu potencial agrícola.

Em zoneamentos agroclimáticos as condições térmico-hídricas são consideradas as que mais influenciam no estabelecimento e desenvolvimento das culturas (Camargo, 1971; Camargo et al. 1974; Costa, 1988; Alfonsi et al. 1995).

Alfonsi et al. (1995) utilizaram dados decendiais de chuvas das principais áreas de cultivo no Estado de São Paulo, para caracterizar a disponibilidade hídrica climática e identificar as melhores épocas de semeadura das culturas de soja, milho, arroz de sequeiro e feijão. Chaim \& Santos (1997), estudando a evolução espaço-temporal da cultura de feijão na região de Ribeirão Preto, concluíram que uma das causas de perdas sucessivas das safras dessa cultura, nos últimos anos, deve-se ao excesso ou falta de chuvas ocorridos na região. Alfonsi \& Victoria Filho (1997), analisando as 
probabilidades da demanda hídrica "ideal" em períodos de dez dias, nas diversas fases fenológicas da cultura do milho no Estado, considerando os cultivares super precoces, precoces e tardios, verificaram que as localidades de Ribeirão Preto, Campinas, Mococa, e Votuporanga apresentam maiores probabilidades de atendimento hidrico em todo o ciclo da cultura, para as épocas tradicionais de semeadura, de outubro a dezembro.

Com base nesta mesma linha de trabalho, Thomé et al. (1996) detiveram-se em avaliar a temperatura do ar, no Estado de Santa Catarina, como o elemento meteorológico que mais influencia na cultura do trigo em todas as fases de seu desenvolvimento. Assim, os autores delimitaram sete sub-regiões de cultivo do trigo no Estado, tomando por base os riscos de ocorrência de geadas entre o pré-espigamento e a pré-maturação; ocorrência de déficit hídrico entre a semeadura e o pré-espigamento e ocorrência de excedente hídrico entre o pré-espigamento e a maturação. Cunha et al. (1997), utilizando técnicas de modelagem e ferramentas de geoprocessamento produziram um zoneamento de riscos climáticos à cultura no Estado do Rio Grande do Sul, conforme a época de semeadura.

Considerando-se a cultura da soja, em Santa Catarina, Thomé et al. (1997) identificaram seis zonas com diferentes épocas favoráveis à semeadura, adotando-se como elementos de julgamento a soma térmica e a deficiência hídrica por decêndios.

Para a cultura do milho, foram consideradas no julgamento a temperatura mínima mensal, a probabilidade mensal de ocorrência de geada e a deficiência hidrica no período de floração, permitindo o estabelecimento de oito zonas favoráveis ao plantio desta cultura (Thomé et al., 1997).

Pezzopane et al. (1997) propuseram um zoneamento climático para a região sul do Estado do Espírito Santo, com base na deficiência hídrica, visando estabelecer a perda de produtividade potencial do feijoeiro, em duas épocas de plantio, concluindo que as perdas médias podem alcançar entre $60 \%$ a $80 \%$, na região leste da bacia do Rio Itapemirim. quando o plantio é realizado nos períodos de outubro e março, respectivamente. 
Sans et al. (1997), estudando os riscos climáticos para a cultura do milho nos Estados de Minas Gerais, Goiás, Tocantins, Mato Grosso e Mato Grosso do Sul, utilizando a distribuição de freqüência dos índices de atendimento às necessidades hídricas da cultura, verificaram que o mês de outubro é o mais indicado ao plantio, aumentando o risco climático à medida que atrasa a semeadura, devido principalmente à redução do armazenamento de água no solo.

Como na elaboração de um zoneamento são utilizados dados e informações multi e interdisciplinares, procura-se o aprimoramento de técnicas e metodologias que propiciem a integração das variáveis ambientais de forma ágil e a menos tendenciosa possível.

\subsection{Sistemas de Informações Geogrảficas - SIG's}

Os Sistemas de Informações Geográficas - SIG's podem ser definidos como sistemas destinados ao tratamento automatizado de dados georreferenciados. Esses sistemas são capazes de manipular uma grande quantidade de dados, provenientes de diversas fontes e formatos, em um ambiente computacional ágil, capaz de integrar as informações espaciais temáticas e de gerar novos dados derivados dos originais (Oliveira Junior, 1994) .

Os SIG's vêm encontrando uma gama de utilização, principalmente na análise e monitoramento ambientais, no planejamento de uso da terra rural e urbana e nos estudos dos recursos naturais (Alves, 1990). Esta mesma opinião é compartilhada por Miranda et al. (1996), que enfatizam serem os SIG's ferramentas cada vez mais utilizadas nos processos de planificação econômica, territorial e ambiental. Uma das principais aplicações dos SIG's é nortear a tomada de decisões por parte dos órgãos gerenciadores, quanto à utilização sustentável dos recursos naturais (Muller. 1985). 
Young (1986), após extensa revisão da literatura e em encontros com pesquisadores europeus e norte-americanos, verificou que não existia nenhum SIG que atendesse a todas as necessidades dos usuários, sendo a sua escolha produto dos seus atributos de análise, dos custos do software e hardware, de estabelecimento de equipes treinadas e de aquisição de dados.

Segundo Alves (1990), nos EUA, no ano de 1989, foram registrados 62 SIG's, cada um com capacidade própria de armazenar, recuperar e analisar diferentes tipos de dados. A utilização de SIG's para fins agrícolas mostra-se bastante eficiente, visto que introduz uma nova ferramenta para seleçã̃o de áreas com diferentes potencialidades de utilização (Sismanoglu et al., 1997). A evolução de técnicas computacionais tem possibilitado automatizar grande parte dos trabalhos, facilitando a integração de diferentes tipos de informações geográficas durante uma análise ambiental (Koffler, 1996). Entre essas técnicas, destaca-se a utilização da modelagem cartográfica, estruturada no encadeamento de regras de transformação espacial de dados geográficos mapeados (Ferreira, 1996).

A estruturação de uma base de dados é facilitada pela automatização na produção dos mesmos. Os dados utilizados em SIG's são classificados por Burrough (1988) como espaciais e não-espaciais. O autor considera como fonte de dados espaciais: mapas, produtos de sensores remotos. fotografias aéreas, relatórios de dados georreferenciados, relatórios de censos e outros levantamentos onde a natureza dos dados é mais implícita do que explícita. Os dados não-espaciais referem-se a atributos concretos de natureza espacial, com identificadores que possam estar associados a eles, como por exemplo, as estradas podem ser representadas em um mapa de forma diferente (federais, estaduais, municipais e vicinais). Todos esses dados podem ser armazenados e processados à parte dos dados espaciais, desde que possuam identificadores que estejam associados à referida estrada (Vettorazzi, 1992).

Couto \& Vettorazzi (1990) salientam que, em se tratando de SIG's, é fundamental a preocupação com a qualidade dos dados, pois não se deve alimentar o 
sistema com uma quantidade exagerada de informações, tentando suprir dúvidas quanto à confiabilidade dos mesmos.

Vettorazzi (1992) discorre sobre a existência de várias formas de entrada de dados num SIG, tais como: via teclado, usado geralmente para dados não-espaciais; via mesa digitalizadora, quando se trata de dados espaciais; via digitalização por varredura, quando um mapa é transformado em imagem digital através de um "scanner" e proveniente de imagens digitais, quando introduzidos no sistema imagens de satélites, fotografias aéreas e outros tipos de imagens.

Quando se trata de digitalização (processo que possibilita converter dados espaciais do mapa em formato digital), faz-se o armazenamento de informações como pontos, linhas e áreas que compõem o mapa, convertendo-os em coordenadas ( $\mathrm{x}, \mathrm{y})$ que irão, posteriormente, constituir uma base de dados digitais de acordo com seus atributos. Portanto, cada tema irá compor um plano de informação (PI), conforme exemplificado na Figura 1.

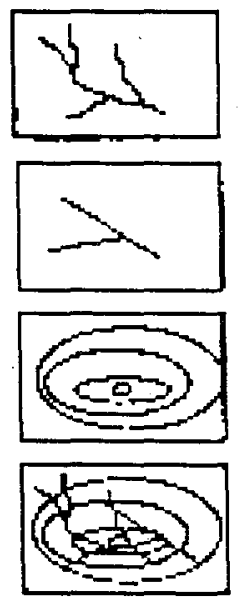

\section{Hidrografia}

Rodovias

Altimatria

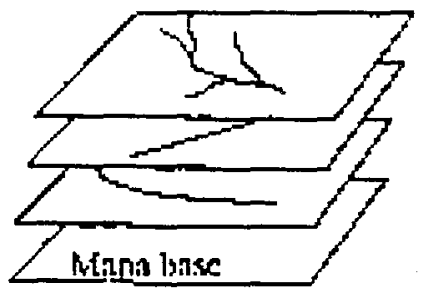

Mapa basc

Figura 1 - Representação de planos de informações - PI's (Adaptado de Eastman, 1992)

Para o gerenciamento da base de dados geográficos, necessita-se que os dados temáticos sejam organizados em quadrículas ou folhas eletrônicas como uma série de 
camadas. O sistema de coordenadas oficial no Brasil é o Sistema Universal Transverso de Mercator (UTM) proposto em 1950 nos EUA, como uma combinação capaz de abranger a totalidade das longitudes (Cintra, 1988).

$\mathrm{Na}$ literatura, encontra-se uma gama variada de trabalhos com diferentes tipos de aplicações do Sistema de Informações Geográficas. Couto \& Vettorazzi (1990) comentam as vantagens do SIG usado na área florestal: pode ler informações contidas em outras bases de dados, avaliar crescimento e rendimento e fazer análise financeira e inventário florestal. Almeida et al. (1990) comentam que o setor florestal tem usado os SIG's para automatização de processos cartográficos, armazenamento, recuperação, manipulação, análises e modelagem de um grande volume de dados.

Segundo Reis (1995), a utilização do SIG IDRISI, para mensurar o processo de assoreamento do reservatório de Capivara, localizado no baixo curso do rio Paranapanema, entre São Paulo e Paraná, mostrou-se eficaz na estimativa de sedimentos de cada parcela da sub-bacia.

Barros (1996) enfatiza a perfeita adequabilidade do geoprocessamento nos estudos ambientais em nível regional e que a utilização de SIG's diminui consideravelmente os custos empreendidos em trabalhos dessa natureza.

Em estudos climáticos, Assad et al. (1993) afirmam que o uso de SIG's, torna-se muito útil na representação espacial de dados pluviométricos, pois possibilita a regionalização das informações, podendo gerar cartogramas, mapas e isolinhas. Miranda et al. (1996) comentam que os SIG's servem como instrumentos complementares para a definição e a simulação de cenários evolutivos, tanto na escala micro (tecnologias agrícolas/sistemas de produção), como na macro (políticas públicas/uso das terras).

Ferraz \& Vettorazzi (1997) concluem que o emprego do Índice de Monte Alegre em SIG na produção de mapas diários de riscos de incêndios em áreas florestais depende da disponibilidade imediata de dados, bem como da atualização constante das informações sobre os meios físico, biótico e antrópico da área em estudo. 
${ }$ Costa et al. (1996) relatam que a delimitação e caracterização de áreas de preservação por meio de SIG's tem permitido quantificar e localizar áreas com usos indevidos, sendo a resolução espacial e a precisão topográfica fatores dependentes do nivel de detalhe requerido na identificação dessas áreas.

As aplicações de SIG's na agricultura são muito diversificadas, pois estão intimamente ligadas ao tipo de usuário que paulatinamente utilizará essa ferramenta (Assad \& Sano, 1993). 


\section{MATERIAL E MÉTODOS}

\subsection{Material}

\subsubsection{Localização da área de estudo}

A área de estudo acha-se situada entre as coordenadas geográficas de $21^{\circ} 00^{\prime} \mathrm{S}$ a $21^{\circ} 30^{\prime} \mathrm{S}$ e $47^{\circ} 30^{\prime} \mathrm{W}$ a $48^{\circ} 00^{\prime} \mathrm{W}$ (Figura 2). Encontra-se localizada na região NE do Estado de São Paulo, cobrindo uma área de 287.057,5 ha, abrangendo 15 municípios: Cravinhos e Serrana, totalmente inseridos na quadrícula, e parcialmente inseridos, os de Pontal, Jardinópolis, Sertãozinho, Ribeirão Preto, Dumont, Barrinha, Pradópolis, Luís Antônio, São Simão, Serra Azul, Altinópolis, Brodósqui e Batatais (Oliveira \& Prado, 1987).

A área foi selecionada em função da sua importância sócio-econômica, além de sua disponibilidade de informações existentes. entre elas, carta de solos em nível de semidetalhe, carta topográfica e dados meteorológicos. 


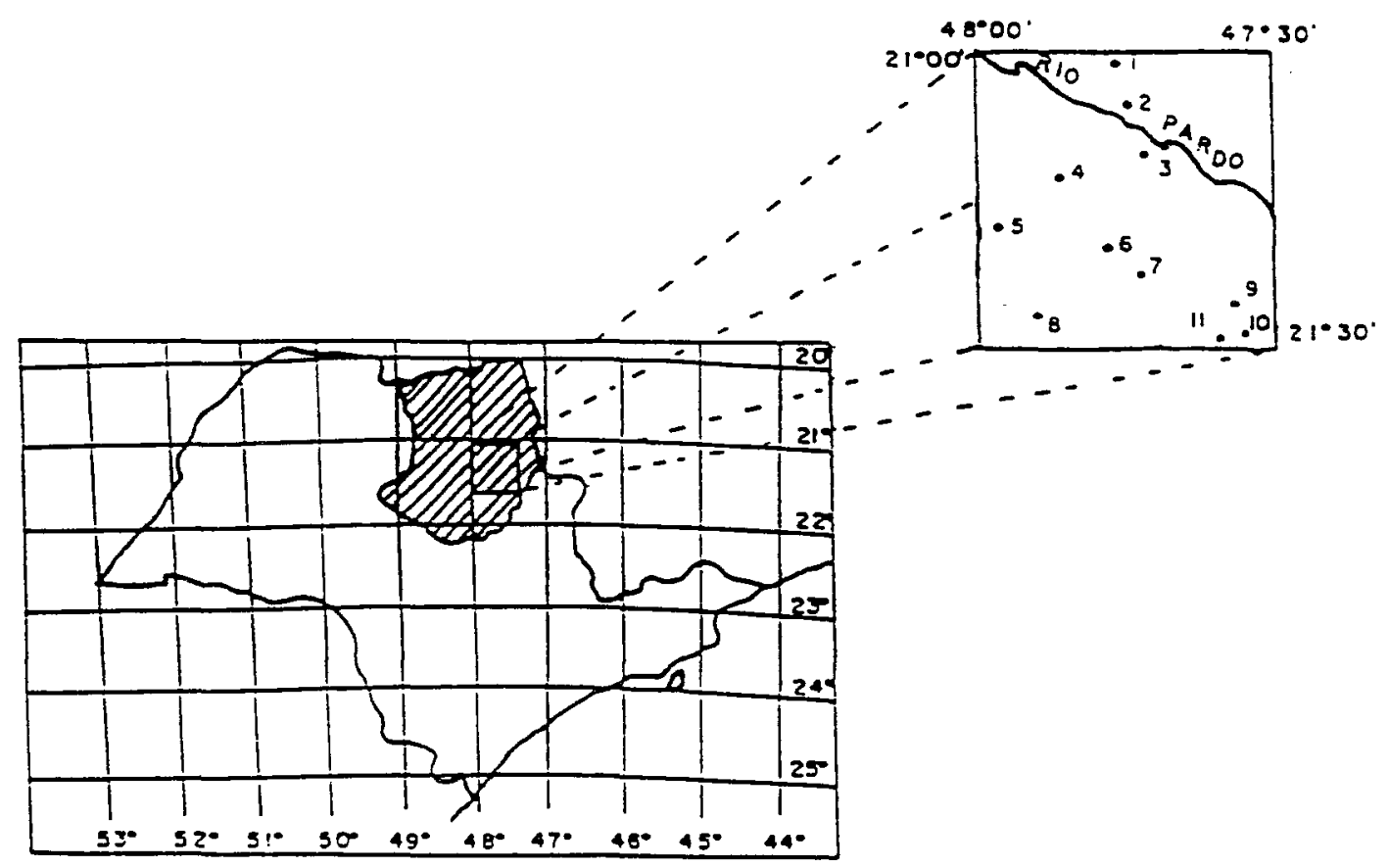

Figura 2 - Localização da área de trabalho

\subsubsection{Características gerais de área de estudo}

\subsubsection{Geologia, relevo, vegetação, clima e uso atual da terra}

Conforme Oliveira \& Prado (1987), do ponto vista geológico, o material de origem é resultado do intemperismo de arenitos das formações Botucatu e Pirambóia, basaltos e diabásios, além de sedimentos aluvionais e continentais indiferenciados e os correlatos à formação Itaqueri. Os sedimentos aluviais ocorrem nas planicies dos principais cursos d'água, com maior importância para as planícies nas margens do rio Pardo, situado a montante da cidade de Ribeirão Preto.

$\mathrm{Na}$ quadricula, aos sedimentos continentais indiferenciados estão associados os Latossolos Vermelho-Amarelo e as Areias Quartzosas Profundas. As formações Botucatu e Pirambóia, pertencentes ao grupo São Bento, surgem nos quadrantes nordeste e sudeste, onde os vigorosos entalhes provocados pelos rios Pardo e Tamanduá removem 
a formação basáltica sobrejacente. Os sedimentos correlatos à formação Itaqueri, grupo Bauru, foram encontrados apenas no extremo centro-oeste, à esquerda da rodovia que liga Ribeirão Preto a Brodósqui, sendo identificados com esse material os Latossolos Vermelho-Amarelos de textura média e argilosa.

Em sua maior extensão, a quadrícula apresenta relevo ondulado, constituído por uma sucessão de morros de topo subaplainado ou arredondado, com longas vertentes, que podem às vezes ultrapassar os 3000 metros de comprimento, com $3 \%$ a $10 \%$ de declividade. Normalmente ocorrem nessa paisagem, pequenos testemunhos tabuliformes, cujas bordas em cornija se relacionam com solos muito rasos.

Essas formas se destacam por estarem revestidas por pastagens ou pela mata que contrastam com a intensa ocupação agrícola. Possui como divisor de águas, ao norte, os limites da bacia do rio Pardo e, ao sul, os da bacia do rio Moji-Guaçu, que corta a quadrícula no sentido NO-SE.

A cobertura vegetal primitiva era constituída pela mata tropical latifoliada e pelos cerradões, nos solos argilosos bem drenados, e cerrados, nos solos arenosos ou de textura média. Nas planícies aluvionais predominavam a mata ciliar, em áreas bem drenadas, e os campos higrófilos, nas áreas mal drenadas. Atualmente, a maior parte dessa vegetação foi substituída por grandes plantações de cana-de-açúcar, culturas anuais e pastagens, exemplificadas na Figura 3. ficando as áreas de menor fertilidade e declivosas com reflorestamento. Da cobertura vegetal natural, observou-se no Inventário Florestal do Estado de São Paulo (IF, 1993), que na quadrícula existem poucas evidências de mata, capoeira, cerrado, cerradão e vegetação de várzea. 


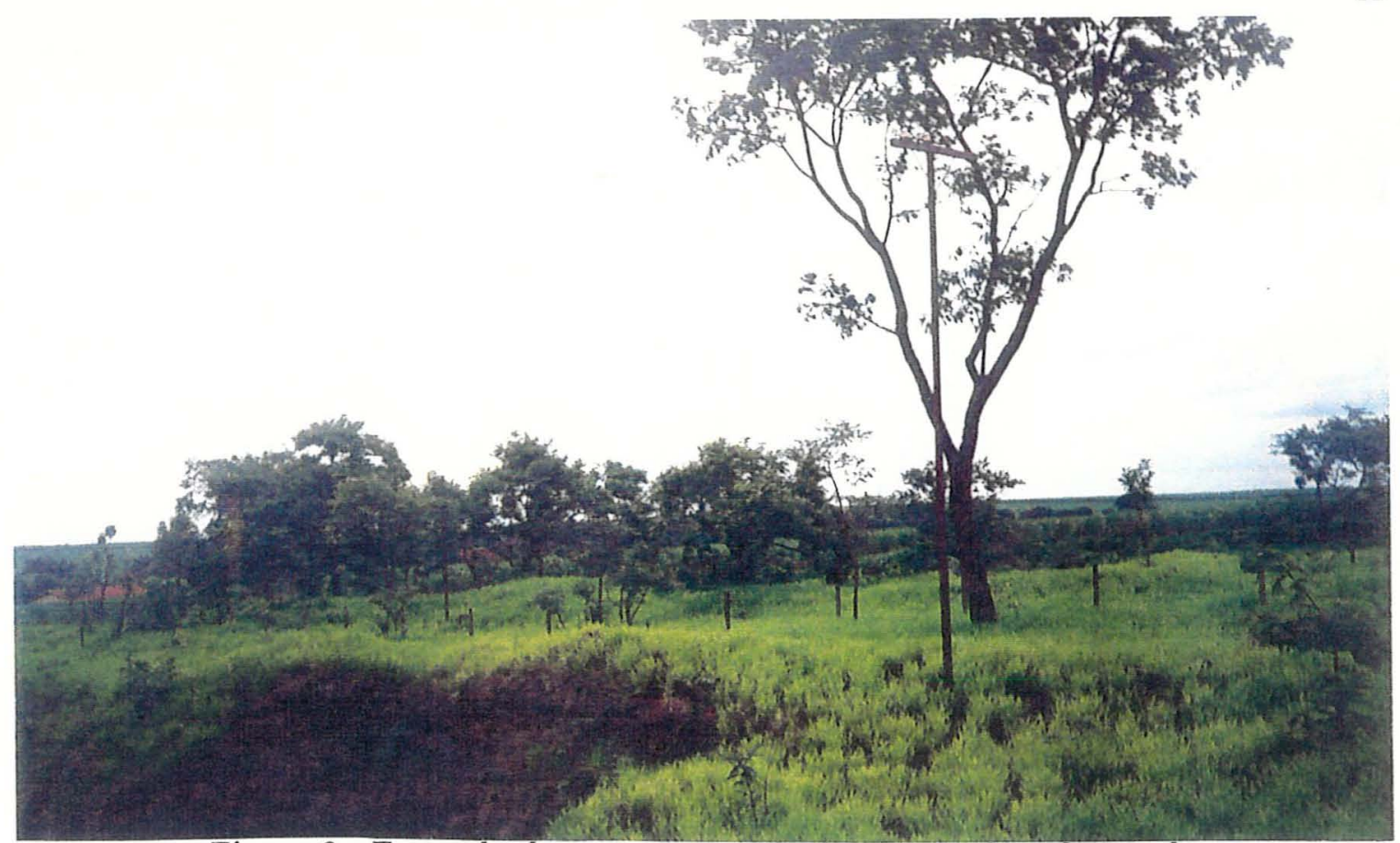

Figura 3 - Exemplo de uso e ocupação do solo na área de estudo

A tipologia climática na maior parte da região, nas áreas baixas com altitude variando de $500 \mathrm{~m}$ a $750 \mathrm{~m}$ é Aw, de acordo com a classificação internacional de Köppen, caracterizada por apresentar verão chuvoso e inverno seco, sendo a temperatura do mês mais frio superior a $18^{\circ} \mathrm{C}$. Nas áreas serranas, o clima é $\mathrm{Cwb}$, temperado com verão chuvoso e inverno seco e temperatura do mês mais quente inferior a $22^{\circ} \mathrm{C}$ (Oliveira \& Prado, 1987).

De acordo com dados mais atuais disponíveis, que são os do Anuário Estatístico do Estado de São Paulo de1993, as culturas de maior representatividade na região são as seguintes: cana-de-açúcar, arroz, amendoim, feijão, algodão, soja, café, milho, mandioca, laranja, além da atividade de pecuária de pequeno e grande porte.

Nas Figura 4 e 5, verificam-se áreas cultivadas com amendoim e cana-de-açúcar, respectivamente, nas proximidades da cidade de Sertãozinho. 


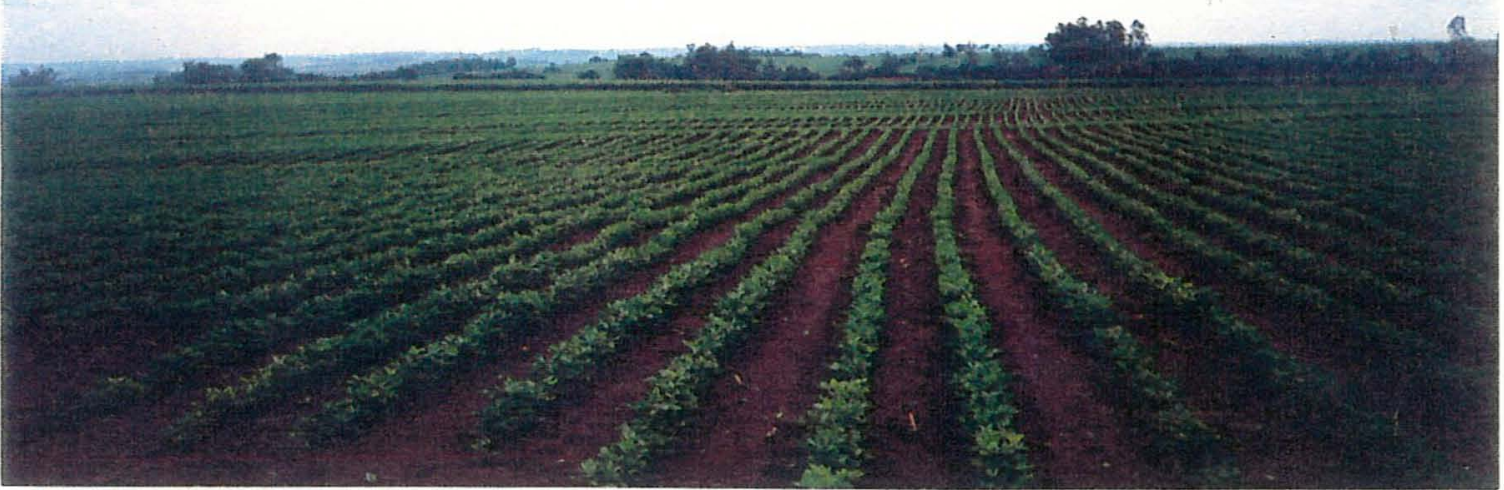

Figura 4 - Exemplo de um plantio de amendoim na área de estudo

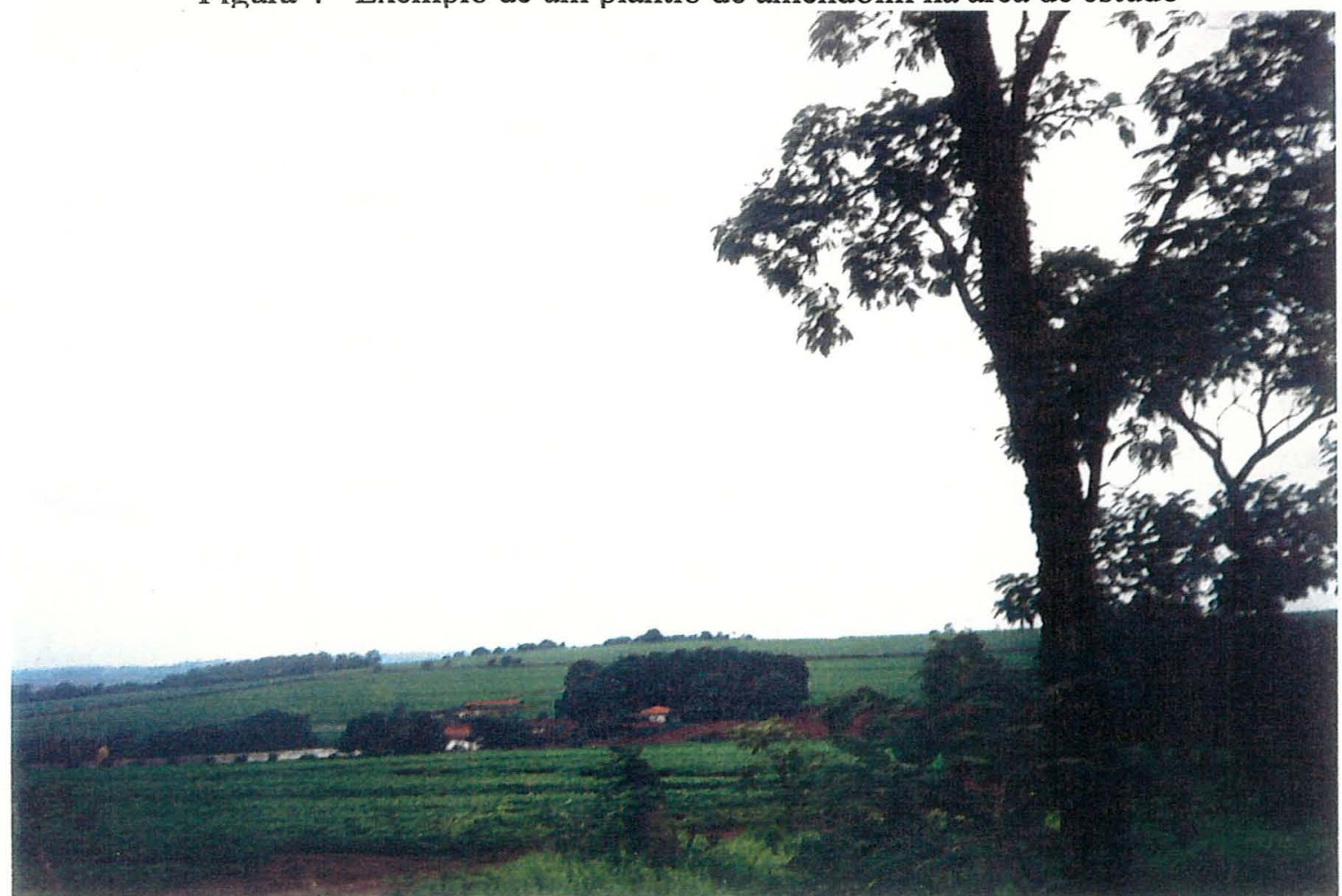

Figura 5 - Plantios de amendoim (primeiro plano) e cana-de-açucar na area de estudo. 


\subsubsection{Solos}

Oliveira \& Prado (1987) citam que na quadrícula em estudo ocorrem as seguintes classes de solos: Latossolo Roxo (63,3\%), Latossolo Vermelho-Escuro (10,4\%), Areia Quartzosa (6,9\%), Solos Litólicos (5,3\%), Solos Hidromórficos (3,7\%) Latossolo Vermelho-Amarelo (3,4\%), Terra Roxa Estruturada (1,8\%), Cambissolo $(0,7 \%)$ e Brunizém Avermelhado (0,1\%).

Na Tabela 1, são apresentadas as classes dos Latossolos, suas respectivas áreas e percentuais de ocorrência.

Tabela 1 - Classes de Latossolos, área e percentual de ocorrência na quadrícula de Ribeirão Preto

\begin{tabular}{ccc}
\hline \multicolumn{1}{c}{ Classes } & Área (ha) & Percentual de ocorrência \\
& & $\mathbf{( \% )}$ \\
Latossolo Roxo & $181.908,50$ & 63,3 \\
Latossolo Vermelho-Escuro & $29.981,50$ & 10,4 \\
Latossolo Vermelho-Amarelo & $11.432,50$ & 3,4 \\
Total & $\mathbf{2 4 3 . 3 2 2 , 5 0}$ & $\mathbf{7 7 , 1}$ \\
\hline
\end{tabular}

\subsubsection{Dados meteorológicos}

Utilizaram-se dados diários de chuva e temperatura de Ribeirão Preto, no periodo compreendido entre os anos de 1967 a 1996. cedidos pelo Instituto Agronômico do Estado de São Paulo - IAC, totalizando 30 anos de dados meteorológicos. Também foram utilizados dados mensais e anuais de chuva de 20 postos, fornecidos pelo Departamento de Águas e Energia Elétrica - DAEE, em sua maioria do mesmo período. Os dados referentes à localidade de São Simão foram reproduzidos das Normais Climatológicas (INMET, 1992), referentes ao período de 1961 a 1990. As estações encontram-se listadas no Quadro 1, com suas respectivas localizações geográficas e 
procedências. As onze primeiras localidades estão inseridas na quadrícula e representadas na Figura 2, numeradas de acordo com a seqüência do Quadrol. As onze restantes foram utilizadas por estarem muito próximas dos limites da área de estudo, de modo a auxiliarem na avaliação das características climáticas da região.

Quadro 1 - Identificação das 22 estações meteorológicas

\begin{tabular}{|c|c|c|c|c|c|c|c|}
\hline & No. & LOCALDADES & Lat. (S) & Long.(W) & Alt.(m) & PERIODO & INSTTTUIÇĀO \\
\hline \multirow{11}{*}{ 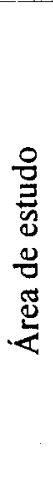 } & 1 & Jardinopolis & $21^{\circ} 01^{\prime}$ & $47^{\circ} 46^{\prime}$ & 580 & $67-96$ & DAEE \\
\hline & 2 & Clube de Regatas & $21^{\circ} 06^{\circ}$ & $47^{\circ} 45^{\prime}$ & 490 & $67-96$ & DAEE \\
\hline & 3 & Ribeirào Preto & $21^{\circ} 11^{\circ}$ & $47^{\circ} 43^{\prime}$ & 621 & $67-96$ & IAC \\
\hline & 4 & Ribeirão Preto & $21^{\circ} 13^{\prime}$ & $47^{\circ} 52^{\prime}$ & 580 & $67-96$ & DAEE \\
\hline & 5 & Faz. Sta. Amélia & $21^{\circ} 18^{\prime}$ & $47^{\circ} 58^{\prime \prime}$ & 590 & $67-96$ & DAEE \\
\hline & 6 & Faz. das Flores & $21^{\circ} 20^{\prime}$ & $47^{\circ} 47^{\prime}$ & 720 & $67-96$ & DAEE \\
\hline & $i$ & Cravinhos & $21^{\circ} 22^{\prime}$ & $47^{\circ} 43^{\prime}$ & 700 & $67-96$ & DAEE \\
\hline & 8 & Capão da Cruz & $21^{\circ} 27^{\prime}$ & $47^{\circ} 54^{\prime}$ & 580 & $67-96$ & DAEE \\
\hline & 9 & Faz. Sta. Clara & $21^{\circ} 25^{\prime}$ & $47^{\circ} 34^{\prime}$ & 720 & $67-96$ & DAEE \\
\hline & 10 & Săo Simão & $21^{\circ} 29^{\prime}$ & $47^{\circ} 33^{\prime}$ & 618 & $61-90$ & INMET \\
\hline & 11 & Prainha do Tamanduá & $21^{\circ} 30^{\prime}$ & $47^{\circ} 36^{\prime}$ & 610 & $67-96$ & DAEE \\
\hline \multirow{11}{*}{ 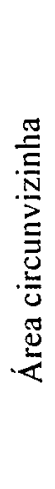 } & 12 & Luís Ántònio & $21^{\circ} 33^{\prime}$ & $47^{\circ} 42^{\prime}$ & 660 & $70-96$ & DAEE \\
\hline & 13 & Usina Sta. Rita & $21^{\circ} 44^{\prime}$ & $47^{\circ} 38^{\prime}$ & 550 & $70-96$ & DAEE \\
\hline & 14 & Faz. Cascata & $21^{\circ} 40^{\prime}$ & $+7^{\circ} 30^{\prime}$ & 700 & $67-96$ & DAEE \\
\hline & 15 & Sta. Rita do P. Quatro & $21^{\circ} 42^{\prime}$ & $47^{\circ} 28^{\circ}$ & 780 & $82-96$ & DAEE \\
\hline & 16 & Bom Sucesso & $21^{\circ} 33^{\prime}$ & $47^{\circ} 23^{\prime}$ & 740 & $72-96$ & DAEE \\
\hline & 17 & Faz. Morrinhos & $21^{\circ} 32^{\prime}$ & $47^{\circ} 13^{\prime}$ & 610 & $69-96$ & DAEE \\
\hline & 18 & Faz. São Lorenço & $21^{\circ} 22^{\prime}$ & $47^{\circ} 26^{\prime}$ & 580 & $67-96$ & DAEE \\
\hline & 19 & Faz. Graciosa & $21^{\circ} 19^{\prime}$ & $47^{\circ} 22^{\prime}$ & 650 & $67-96$ & DAEE \\
\hline & 20 & Sta. Cruz da Esperança & $21^{\circ} 17^{\prime \prime}$ & $+7^{\circ} 26^{\prime}$ & 600 & $73-96$ & DAEE \\
\hline & 21 & Laje & $21^{\circ} 13^{\prime}$ & $47^{\circ} 18^{\prime}$ & 800 & $71-96$ & DAEE \\
\hline & 22 & Pradópolis & $21^{\circ} 22^{\prime}$ & $48^{\circ} 04^{\prime}$ & 540 & 67.96 & DAEE \\
\hline
\end{tabular}




\subsubsection{Equipamentos}

O sistema computacional utilizado consistiu-se de um microcomputador AT 486-DX4, 100 Megahertz, com 16 MB de memória RAM e disco rígido de 1,2 GB, acoplado a uma mesa digitalizadora Summagraphics Microgrid III e a uma impressora a jato de tinta colorida HP Deskjet 660C, pertencente ao Laboratório de Geoprocessamento do Departamento de Engenharia Rural da ESALQ/USP.

\subsubsection{Softwares}

Foram utilizados os seguintes softwares, no processamento e análise dos dados: IDRISI for Windows, versão 2.0, desenvolvido pelo Departamento de Geografia da Clark University (EUA), contendo módulos de processamento de imagens, análises multitemporal e geográfica, modelagem digital do terreno e banco de dados. A escolha deste sistema foi devido a facilidade de sua utilização em microcomputadores, por atender ao propósito do trabalho, pelo interesse de aprendizagem de novas ferramentas de integração de variáveis que propiciem limitar o subjetivismo, pela possibilidade de acesso ao Laboratório de Geoprocessamento do Departamento de Engenharia Rural da ESALQ/USP para manipular dados de diversas fontes com rapidez e precisão.

O software TOSCA 2.12 foi empregado na digitalização dos mapas de solos e relevo.

Os dados meteorológicos foram processados por meio de planilhas, utilizando o software EXCEL da Microsoft, versão 7.0.

Os mapas das variáveis climáticas temperatura do ar e chuva foram gerados a partir do software SURFER for Windows v. 5.0 e posteriormente exportados para o IDRISI para as análise subsequentes. 


\subsection{Métodos}

O procedimento metodológico utilizado, baseou-se em trabalhos que empregaram o uso de Sistemas de Informações Geográficas em zoneamentos ambientais, com ênfase na utilização de uma base de dados composta de informações procedentes de mapas de solos, relevo e clima, conforme apresentado em fluxograma (Figura 6). Os arquivos foram todos georreferenciados e o tipo de projeção utilizada foi a Universal Tranversa de Mercator (UTM.

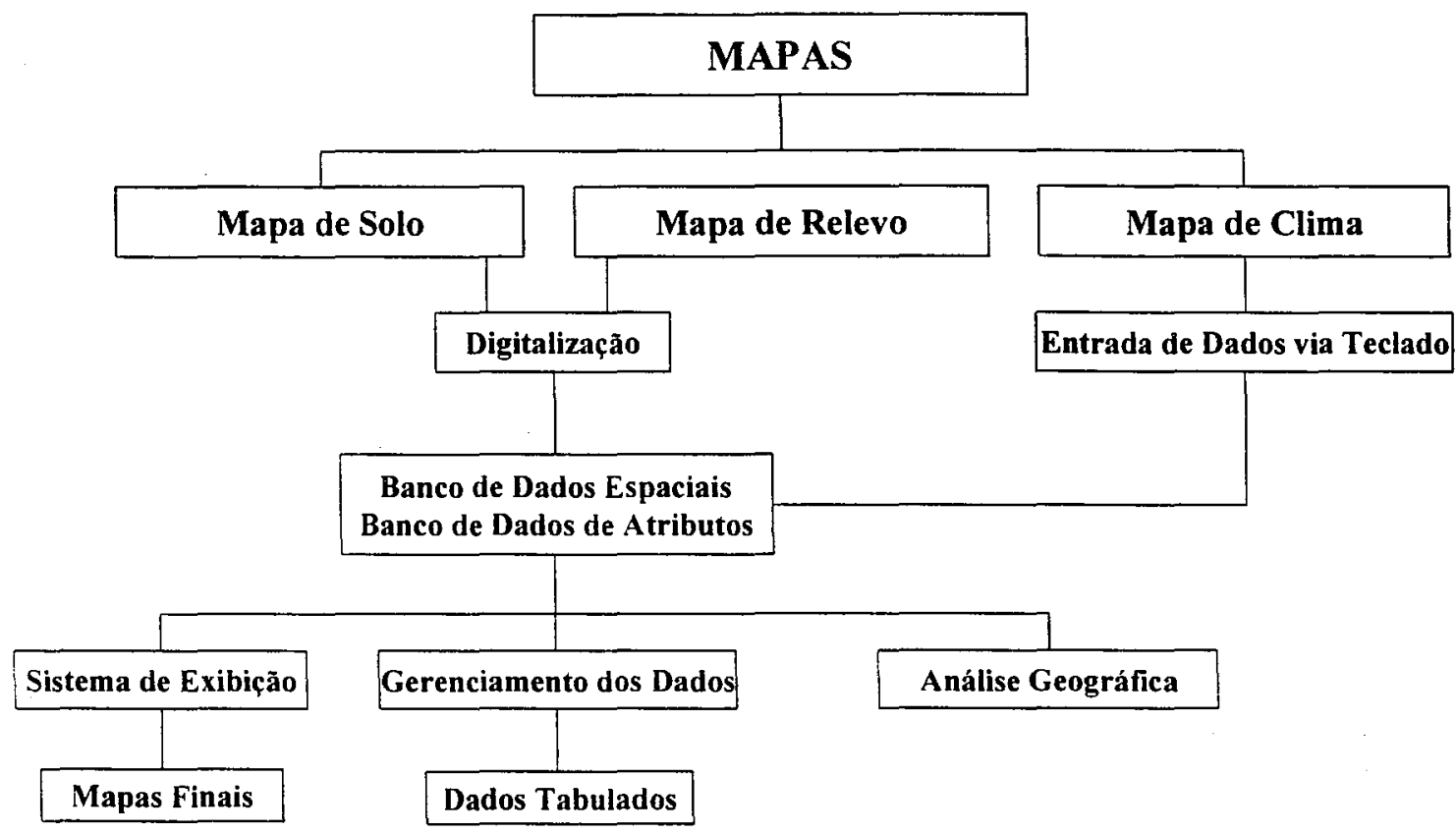

Figura 6 - Fluxograma seqüencial da estrutura de obtenção, processamento e produto final dos dados analisados dentro do Sistema de Informações Geográficas. 


\subsubsection{Solos}

Utilizou-se o mapa de solos em nível de semidetalhe, na escala 1:100.000, elaborado pelo Instituto Agronômico do Estado de São Paulo - IAC (Oliveira \& Prado, 1987).

Palmieri \& Larach (1996) comentam que na escala de semidelalhe o objetivo do mapa de solos é selecionar áreas com maior potencial de uso intensivo, identificando problemas quanto ao uso e conservação dos mesmos.

O mapa de solos foi digitalizado por meio do software TOSCA 2.12, produzindose uma carta com nova legenda, considerando-se as classes de solos em função das características físicas dominantes.

Dessa maneira, adotou-se as restrições edáficas citadas por Oliveira \& Prado (1987) para cada classe de solos, conforme descrição a seguir:

Latossolo Roxo (LR) - são solos com propriedades físicas muito boas e grande potencial agrícola. Praticamente não apresentam limitações, salvo a declividade que em condição pouco acentuada já exige práticas conservacionistas simples para evitar os processos erosivos.

Latossolo Vermelho-Escuro (LE) - geralmente são solos com boas propriedades físicas. A baixa fertilidade e a limitada capacidade de retenção de água constituem as limitações mais sérias desses solos.

Latossolo Vermelho-Amarelo (LV) - a baixa fertilidade aparente e a limitada capacidade de retenção de água constituem as limitações mais sérias desses solos, especialmente naqueles com acentuados teores de areia.

Terra Roxa Estruturada (TE) - são solos com fertilidade natural elevada, com boa disponibilidade de nutrientes. Esses solos são muito adequados à agricultura, sendo o declive nas áreas mais movimentadas (sul e norte da quadrícula) o fator mais restritivo. 
Brunizem Avermelhado (Bv) - são solos de elevado potencial nutricional e características fisicas bastante favoráveis. O relevo fortemente ondulado constitui, contudo, séria limitação de uso, dai estarem ocupados essencialmente com pastagens.

Areia Quartzosa Profunda (AQ) - são solos com sérias limitações devido à reduzida capacidade de retenção de água e de nutrientes, ao baixo potencial nutricional e à acentuada erodibilidade.

Solos Hidromórficos (Hi) - são solos com sérios problemas de uso devido ao lençol freático elevado.

Solos Litólicos (Li) - a reduzida espessura desses solos e o relevo movimentado impedem o seu uso com agricultura extensiva. Algumas áreas aplainadas, de topo, são aproveitadas após a retirada das pedras, com cultura de algodão.

Cambissolo (Cb) - são solos de mediano potencial agrícola, cujos fatores restritivos mais importantes são as limitações de drenagem interna e/ou de fertilidade e, ocasionalmente, riscos de inundação, pois são de planícies aluvionais.

Para apresentar as unidades de mapeamento em função das características determinantes quanto ao uso, fez-se a reclassificação do mapa com o objetivo de preparar o P.I. de solo para o cruzamento com os P. I.'s de relevo e clima.

$\mathrm{Na}$ reclassificação do P. I. de solo, procurou-se seguir as restrições edáficas descritas e agrupar as classes em função de suas limitações quanto ao uso. Assim, considerou-se:

0 - para todas as àreas que não seriam aproveitadas para uso agroecológico, tais como: áreas urbanas, corpos d'água, terrenos para extração de argila e bancada de laterita.

1 - para a classe dos Latossolos

2 - para as Terras Roxas Estruturadas e os Brunizens Avermelhados

3 - para as Areias Quartzosas Profundas

4 - para os Solos Hidromórficos

5 - para os Solos Litólicos

6 - para os Cambissolos 


\subsubsection{Relevo}

A base de relevo foi produzida a partir da carta planialtimétrica da Região Administrativa de Ribeirão Preto, na escala 1:250.000 do IBGE (Brasil, 1978), com eqüidistância entre as curvas de nível de $50 \mathrm{~m}$. Para compor o Plano de Informação - PI de relevo, digitalizou-se a carta por meio do software TOSCA 2.12, sendo posteriormente convertida em imagem.

Para a obtenção do P.I. de relevo foi feita uma reclassificação contando coma as seguintes classes:

1 - para as áreas que possuíssem altitudes entre $400 \mathrm{~m}$ a $500 \mathrm{~m}$.

2 - para as áreas que possuíssem altitudes entre $500 \mathrm{~m}$ a $600 \mathrm{~m}$.

3 - para as áreas que possuíssem altitudes entre $600 \mathrm{~m}$ a $700 \mathrm{~m}$.

4 - para as áreas que possuíssem altitudes entre $700 \mathrm{~m}$ a $800 \mathrm{~m}$.

5 - para as áreas que possuissem altitudes entre $800 \mathrm{~m}$ a $900 \mathrm{~m}$.

6 - para as áreas que possuíssem altitudes entre $900 \mathrm{~m}$ a.1000 m.

Este modelo digital de elevação foi separado em intervalos de 100 metros, visando avaliar as variações topoclimáticas da área, principalmente quanto aos aspectos de temperatura do ar. Como a temperatura apresenta variação inversa ao aumento da altitude, devido à descompressão adiabática à medida que o ar se eleva na atmosfera, ocorrendo um resfriamento médio de $0,6^{\circ} \mathrm{C}$ a cada 100 metros, procurou-se correlacionar a variabilidade média em função das cotas hipsométricas, na quadrícula. 


\subsubsection{Clima}

O clima refere-se às características da atmosfera, inferidas de observações contínuas durante um período de aproximadamente 30 anos (Ayoade, 1996). Assim, tomando como base os dados de chuva e de temperatura do ar, referentes ao período de 1967 a 1996 das estações citadas no Quadro 1, procurou-se caracterizar o regime térmico-hídrico da área de estudo, dando ênfase às informações apresentadas a seguir:

\subsubsection{Temperatura do ar}

Analisaram-se os dados diários, mensais e anuais de temperatura do ar para a localidade de Ribeirão Preto. Na localidade de Pradópolis, fez-se a avaliação do regime térmico considerando os dados mensais e anuais. Para a localidade de São Simão, adotou-se os dados das normais climatológicas (INMET, 1992). Visando suprir a necessidade dos dados de temperatura do ar para as demais localidades, foram utilizadas equações de regressão ajustadas para o Estado de São Paulo, com base nos fatores geográficos altitude e latitude, para estimar valores de temperaturas médias e extremas (Pedro Junior et al., 1991).

A fim de subsidiar o planejamento de uso da terra, principalmente na introdução de novas culturas e animais exóticos, elaborou-se um mapa de distribuição espacial das menores temperaturas mínimas, em termos de médias, na quadrícula.

\subsubsection{Chuva}

Realizou-se a análise dos eventos médios mensais, sazonais e anuais, objetivando-se identificar: início, término e duração da estação chuvosa. Também foram 
utilizados os dados das normais climatológicas (INMET, 1992) para a localidade de São Simão.

Objetivando caracterizar as chuvas diárias na região e, considerando-se a disponibilidade de dados diários de uma série de 30 anos, apenas da estação meteorológica de Ribeirão Preto (IAC), procurou-se fazer uma análise desses dados com o propósito de identificar informações adicionais de interesse. Avaliou-se a freqüência da quantidade de chuva armazenada em qüinquídios para cada mês da série, afim de fornecer subsídios para projetos de irrigação, indicando o total de chuva que pode ser esperado nesses intervalos de tempo e aos extensionistas, para orientação ao produtor, no planejamento do calendário agrícola.

A água da chuva exerce ação erosiva sobre o solo mediante o impacto das gotas que caem com velocidade e energia variáveis, sendo a intensidade da chuva o fator mais importante nos estudos de erosão hídrica dos solos (Castro, 1980 e Brady, 1989). O conhecimento da chuva diária máxima provável é importante para subsidiar trabalhos como conservação do solo, de estradas e barragens (Vieira et al., 1991). No sentido de avaliar as chuvas intensas, à semelhança de estudos como os de Pfafstetter (1957), identificou-se as chuvas máximas diárias e analisou-se os registros desses eventos extremos, em pluviogramas, a fim de verificar as relações entre intensidade e duração. expressas na unidade em $\mathrm{mm} \cdot \mathrm{h}^{-1}$.

Para identificar a época mais provável de ocorrência de chuvas máximas, adotouse a distribuição de probabilidade descrita por Gumbel, citado por Chow (1964), por ser a mais apropriada para descrever eventos extremos (Leopoldo et al., 1984, Assis et al., 1996, Eltz et al., 1992), utilizando-se do software Statgraphics Plus 6,0. O período de retorno $(\mathrm{T})$ de um evento máximo anual de chuva é definido como o período, em anos, em que o evento pode ser igualado ou excedido. pelo menos uma vez, em média, a cada $T$ anos. 


\subsubsection{Balanço hídrico}

Para estimar o déficit hídrico no solo, realizou-se balanços hídricos climáticos, utilizando-se o programa de Barbieri et al. (1991), com base na metodologia de Thornthwaite \& Mather (1955), para a capacidade de água disponivel - CAD de 100mm. Este programa utiliza as seguintes equações para calcular a evapotranspiração potencial:

$$
E T P p=16\left(10 \frac{T i}{I}\right)^{a} \quad T i>0^{\circ} \mathrm{C}
$$

em que: ETPp = evapotranspiração potencial média mensal padrão, mm.mês ${ }^{-1}$;

$\mathrm{Ti}=$ temperatura média mensal, ${ }^{\circ} \mathrm{C}$;

I = índice de calor da região, calculado com os valores normais.

$$
a=6,7510^{-7} I^{3}-7,7110^{-5} I^{2}+1,791210^{-2} I+0,49239
$$

em que: $a=$ coeficiente empírico, calculado em função do índice de calor da região.

$$
\begin{gathered}
I=\sum_{i=1}^{12}(0,2 \quad T i)^{1.514} T i>0^{0} C \\
E T P=E T P p \frac{N}{12} \frac{N D}{30}
\end{gathered}
$$

em que: ETP = evapotranspiração potencial mensal, mm.mês ${ }^{-1}$;

$\mathrm{N}=$ fotoperiodo médio mensal, $\mathrm{h}$;

$\mathrm{ND}=$ número de dias do mês. 


\subsubsection{Tipologia climática}

Visando simplificar e enquadrar a área de estudo nos diversos padrões climáticos existentes, utilizou-se os pressupostos estabelecidos nas classificações climáticas de Köppen (1918) e de Thornthwaite (1948).

\subsubsection{Cartas climáticas}

De posse dos dados médios foram elaboradas as seguintes cartas climáticas: chuva média anual, temperatura média anual, temperatura mínima mensal, tipologia climática de Thornthwaite (1948) e deficiência hídrica anual. Tais cartas foram geradas, utilizando-se conjuntamente os softwares SURFER e IDRISI. Os dados foram interpolados para uma grade de $30 \mathrm{~m}$ em toda a área de abrangência, adotando-se o método da "Krigagem". Em seguida recortou-se cada carta no tamanho da área de estudo, considerando-se o mesmo número de linhas e de colunas dos mapas de solos e de relevo. Após gerados estes mapas, fez-se a reclassificação em intervalos de classes, objetivando avaliar a distribuição espacial desses elementos climatológicos.

\subsubsection{Deficiência hídrica}

O Plano de Informação de deficiência hídrica foi feito a partir dos valores estimados pelo balanço hídrico. As classes de deficiência hídrica adotadas neste trabalho foram definidas no intervalo de $30 \mathrm{~mm}$.

Considerou-se para a região a seguinte classificação de deficiência hídrica anual: 
1 - se a deficiência hídrica anual representar de 0\% a 15\% da ETP no período seco, adotou-se como áreas que possuem pouca ou nenhuma deficiência, o que para a região representa o intervalo de $0 \mathrm{~mm}$ e $30 \mathrm{~mm}$, aproximadamente.

2 - se a deficiência hídrica anual representar de $15 \%$ a $30 \%$ da ETP no período seco, adotou-se como áreas que possuem deficiência moderada, representando valores de $30 \mathrm{~mm}$ a $60 \mathrm{~mm}$, aproximadamente.

3 - se a deficiência hídrica anual representar entre 30\% a 45\% da ETP no período seco, adotou-se como áreas que possuem deficiência acentuada, aproximadamente entre $60 \mathrm{~mm}$ a $90 \mathrm{~mm}$.

\subsubsection{Zoneamento agroecológico}

\subsubsection{Critérios de avaliação da capacidade de uso das terras}

Considerando-se a complexidade de julgamento das variáveis analisadas, foi elaborado um conjunto de critérios quanto a capacidade de uso. As limitações das terras baseiam-se, primordialmente, nas combinações do efeito do clima, relevo e características permanentes do solo, que limitam o uso agrícola e/ou impõem riscos de degradação pela erosão acelerada. Os critérios utilizados foram, basicamente, os preconizados por Lepsch et al. (1990), assim classificados:

a) Estabilidade do solo, que depende da declividade e da erodibilidade;

b) Impedimento à mecanização devido a pedregosidade e profundidade dos sulcos de erosão existentes, encharcamento;

c) Profundidade do solo em função da falta ou excesso de umidade; 
d) Ambiente ecológico em função especialmente das condições climáticas, notadamente o regime pluviométrico. Adicionou-se a deficiência hídrica anual como elemento de julgamento.

O método preconizado pelo Serviço de Conservação do Solo dos Estados Unidos, sintetizado por Brady (1989) e citado em Lepsch et al. (1983), Lepsch et al. (1990) e Bertoni \& Lombardi Neto (1990) foi adotado por ser o mais simples, considerando apenas um nível de manejo e estabelecendo as classes mais em função da suscetibilidade à erosão e indicação de práticas conservacionistas.

Lepsch et al. (1990) comentam que o sistema de capacidade de uso apresenta uma desvantagem sobre o de aptidão agrícola, devido considerar unicamente o nivel de manejo $\mathrm{C}$ (ou $\mathrm{C}$ intermediário para $\mathrm{B}$ ), porém sua vantagem é indicar práticas conservacionistas do solo dentro das terras próprias para lavouras e a de discriminar melhor aquelas mais adaptáveis para cultivos anuais (classes I, II e III) e daquelas para cultivos perenes (classe IV). Bertoni \& Lombardi Neto (1990) sintetizam que basicamente as terras podem ser divididas em três categorias: cultiváveis; cultiváveis apenas em casos especiais de algumas culturas permanentes e adaptadas em geral para pastagens ou florestas e terras que não se prestam para vegetação produtiva.

Partindo da premissa que a agricultura no estado de São Paulo, em sua maioria, utiliza-se dos niveis de manejo $\mathrm{B}$ e $\mathrm{C}$, adotou-se os critérios do sistema de capacidade de uso, além dos critérios adotados por Ramalho Filho et al. (1995), com relação aos graus de limitação do solo por deficiência de água, visando adicioná-los aos critérios propostos neste trabalho, quanto ao déficit hídrico anual.

Das oito classes preconizadas pela metodologia de capacidade de uso, foram adotadas seis classes em função das características do solo na área de trabalho, descritas a seguir: 
Classe I - os solos incluídos nesta classe possuem poucas restrições quanto à sua utilização. Podem ser cultivados com intensidade, necessitando apenas de práticas comuns de mecanização agrícola para conservar a produtividade, o que inclui utilização de fertilizantes, calagem, reposição dos adubos verdes e resíduos de culturas, adotando-se também rotação de culturas (Brady, 1989). Considerouse pertencentes a esta classe os Latossolos, nas condições de relevo com altitudes variando de $400 \mathrm{~m}$ a $700 \mathrm{~m}$ e deficiência hídrica pertencente as condições 1 e 2 , recebendo assim, a denominação de: Agricultura I .

Classe II - os solos desta classe possuem algumas limitações que reduzem a escolha das culturas ou exigem práticas moderadas de conservação. Podem ser utilizados pelas mesmas culturas da classe I, no entanto, exigem certas práticas de conservação devido a: declividade suave; riscos moderados de erosão; inadequada profundidade; estrutura do solo com possibilidades de trabalho limitada (Brady, 1989). Nessa classe enquadraram-se os Latossolos, a Terra Roxa Estruturada e Brunizem Avermelhado, na faixa de relevo também de $400 \mathrm{~m}$ a 700 $\mathrm{m}$, porém a deficiência hídrica anual enquadrou-se nas condições 2 e 3 . Adotouse a denominação de: Agricultura II.

Classe III - terras cultiváveis que requerem medidas intensivas ou complexas, com práticas especiais de conservação do solo, sendo a topografia o maior fator de limitação. Considerou-se, nesta classe os Latossolos, a Terra Roxa Estruturada e o Brunizem Avermelhado, estando o relevo na faixa dos $700 \mathrm{~m}$ a $1000 \mathrm{~m}$, incluindo todas as condições de deficiência hídrica anual. Com essas características denominou-se de: Agricultura III.

Classe IV - solos dessa classe são utilizáveis para lavoura, mas com limitações muito severas quanto à escolha de culturas, sendo necessário manejo muito 
cuidadoso. Atuam sobre esses solos, fatores limitantes como: encostas íngremes, erosão profunda no passado, alcalinidade ou salinidade severa e outras. Nessa classe, não foi enquadrado nenhum tipo de solo na área em estudo.

Classe V a VII - os solos dessas classes não se prestam à agricultura. Os solos da classe V estão sujeitos a limitações que comprometem a sua utilização com segurança. Identificou-se com essas condições os Solos Hidromórficos e os Cambissolos, em todas as classes de relevo e de deficiência hídrica. O tipo de uso considerado foi: Pecuária.

Classe VI - solos dessa classe possuem limitações severas que restringem o seu uso, sendo adaptados para algumas culturas perenes, para pastagens ou reflorestamento. Enquadrou-se nessa classe as Areias Quartzosas e os solos Litólicos, em relevo na faixa de $400 \mathrm{~m}$ a $700 \mathrm{~m}$, independente das condições de deficiência hídrica. $O$ agente limitante foi o solo na seleção do tipo de uso, denominado de: Agrossilvicultura.

Classe VII - os solos dessa classe possuem limitações muito severas que restringem seu uso com culturas anuais, pastagem e reflorestamento. Requerem controles extremos quanto a erosão. Considerou-se as Areias Quartzosas e os solos Litólicos, com relevo na faixa de $700 \mathrm{~m}$ a $1000 \mathrm{~m}$, independente das condições de deficiência hídrica. Neste caso, os fatores considerados determinantes foram o solo e o relevo. Quanto ao uso esses solos, foram indicados para: Preservação.

Objetivando elucidar a integração das variáveis ambientais julgadas na metodologia proposta, de acordo com cada critério adotado e seus devidos pesos na 
delimitação das zonas, apresentou-se a Tabela 2, com as classes correspondentes a solo, relevo e deficiência hídrica, que propiciaram o zoneamento agroecológico da quadrícula.

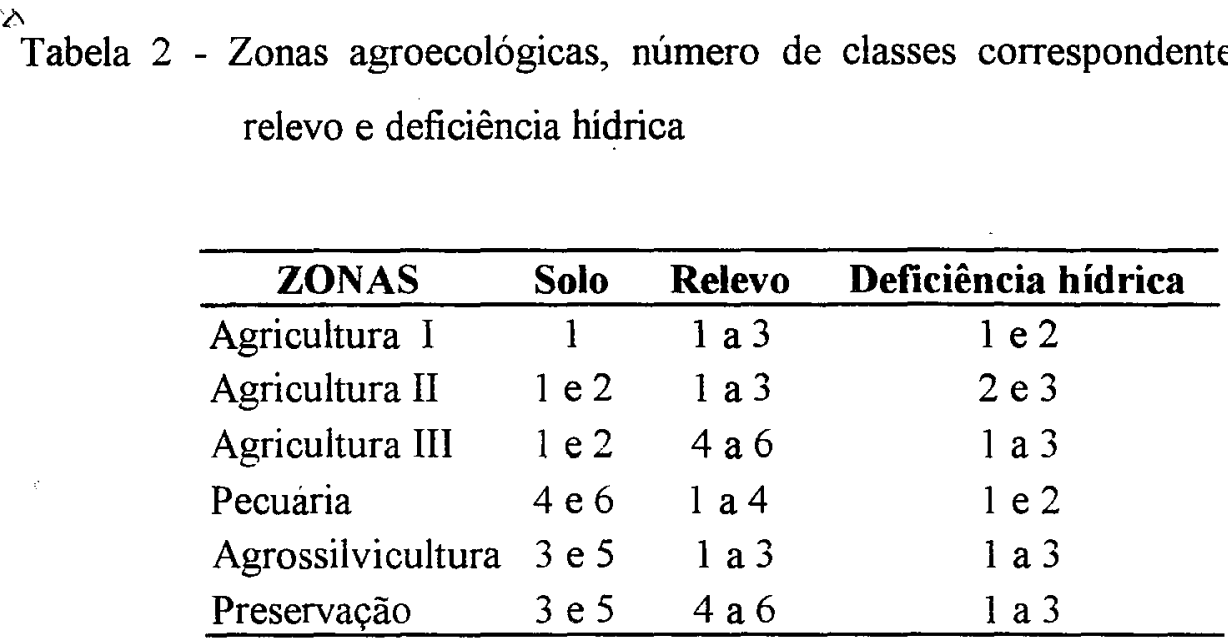

\subsubsection{Cruzamento das informações}

Para o cruzamento dos planos, utilizou-se o grupo de operações do SIG denominado de álgebra com mapas, que se refere ao uso de imagens como variáveis em operações aritméticas normais. O procedimento realiza uma série de operações matemáticas, juntamente com a consulta ao banco de dados (Eastman, 1996).

De posse das imagens de solos e de relevo, realizou-se uma combinação das mesmas para criar uma nova imagem. Para a realização dessa tarefa, utilizou-se o módulo CROSSTAB do menu Analysis/Statistics do IDRISI para Windows. A nova imagem da tabulação cruzada apresentou uma legenda contendo todas as combinações entre as zonas de solos e relevo, na mesma ordem das imagens de entrada. Para obter o terceiro Plano de Informação, utilizou-se a carta de deficiência hidrica, semelhante à imagem de saída dos PI's de solo e relevo. Após a seleção dos índices por classe de uso, fez-se a 
reclassificação, agrupando cada índice com seu número identificador. Nesse momento, foram separadas as áreas que serviriam para uso das que não entrariam no julgamento a saber: área urbana, corpos d'água, terrenos com extração de argila e bancada de laterita.

O mapa final foi elaborado, adotando-se a técnica de reclassificação (módulo RECLASS). Nesta reclassificação, foi dado o valor 0 para as áreas não julgadas quanto ao uso (fundo) e os valores de 1 a 6 para as zonas de interesse em função do uso. De posse das zonas de interesse, utilizou-se a operação de multiplicação (OVERLAY) nas imagens reclassificadas, obtendo-se assim o mapa de zoneamento agroecológico.

Para subsidiar as avaliações quanto ao uso da terra, utilizou-se imagens orbitais obtidas pelo sensor Thematic Mapper (TM), instalado a bordo do satélite LANDSAT - 5, na passagem de 22/11/96, nas bandas: 3 (vermelho) e 4 e 5 (infravermelho próximo e infravermelho médio, respectivamente). Essas informações foram posteriormente checadas a campo, juntamente com a Carta de Utilização da Terra do Estado de São Paulo (1985) e Inventário Florestal (IF, 1993), visando subsidiar a avaliação das condições potenciais de utilização. 


\section{RESUlTADOS E DISCUSSÃo}

\subsection{Solos}

Com relação à distribuição espacial dos solos, gerado a partir da carta de solos do IAC por meio do SIG IDRISI, verificou-se que o Plano de Informação referente a solos ficou representado por nove classes de solos (Figura 7).

Observou se que na quadrícula predominam os Latossolos Roxo - LR $(63,3 \%)$, identificados pela cor cinza, seguido dos Latossolos Vermelho-Escuro - LE $(10,4 \%)$, ilustrados pela cor azul escuro. As Areias Quartzosas - AQ (6,9\%), representadas pela cor rosa, ocorrem mais na parte leste da área, no sentido norte-sul. Já os Solos Litólicos Li $(5,3 \%)$, ocorrem praticamente na parte leste, representados pela cor verde. As menores proporções ficaram com os Solos Hidromórficos - Hi $(3,7 \%)$, representados pela cor amarela clara, acompanhando os cursos d'água. A ocorrència dos Latossolos Vermelho-Amarelo - LV é cerca de $3.4 \%$ da área. Os indícios das Terras Roxas Estruturadas - TE $(1,8 \%)$, observam-se na porção mais ao sul da área, seguindo uma orientação. quase que na direção sudeste-noroeste, ou seja, no sentido São Simão Sertãozinho. As menores manchas de solos ficaram com as classes dos Cambissolo - $\mathrm{Cb}$ $(0,7 \%)$ e Brunizem Avermelhado - Bv $(0,1 \%)$. 


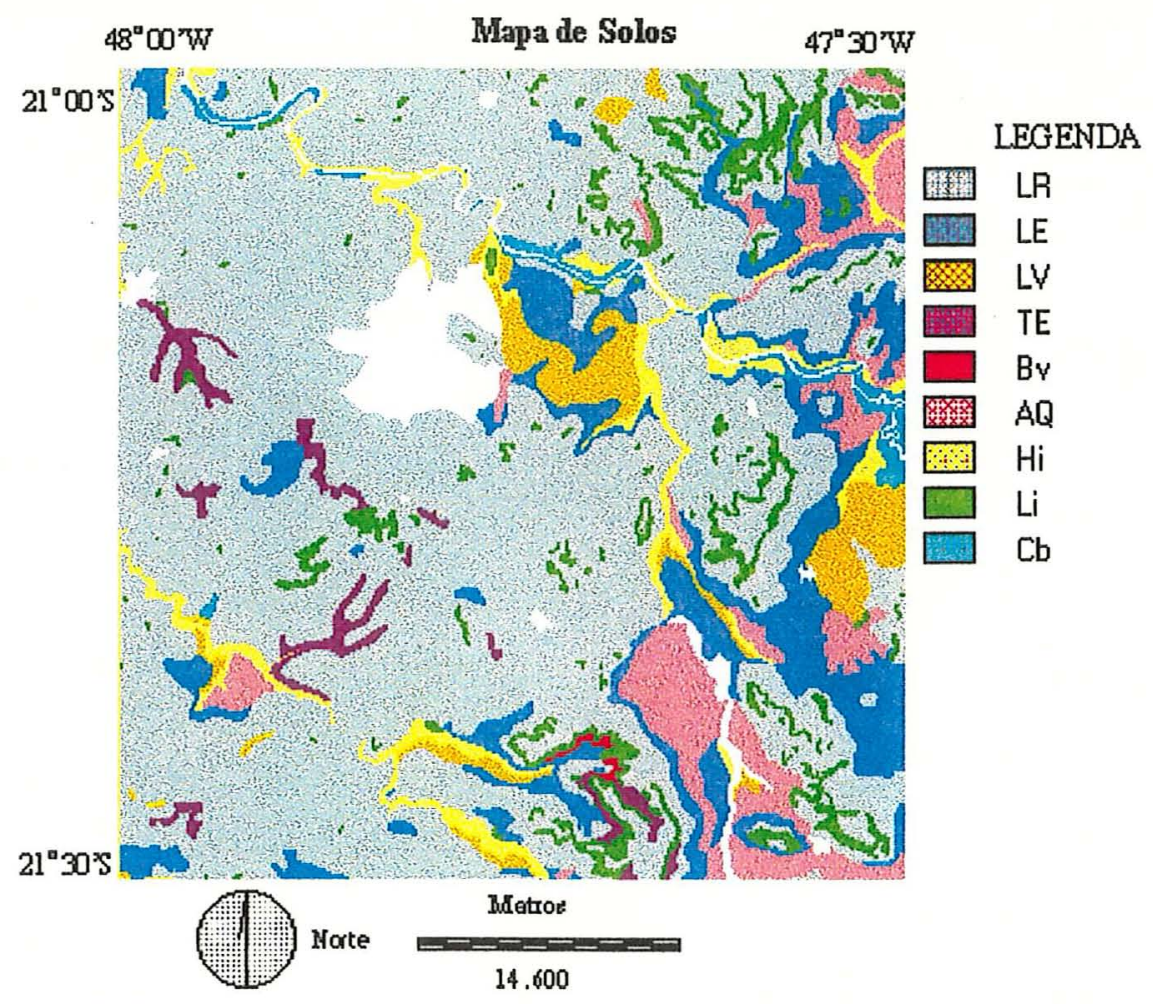

Figura 7 - Mapa de solos da área de estudo.

\subsection{Relevo}

A carta de relevo ficou representada por seis classes hipsométricas (Tabela 3, Figura 8). Cerca de $94 \%$ da área encontra-se na faixa que vai de $500 \mathrm{~m}$ a $800 \mathrm{~m}$.

Por esses dados se deduz que 239.979 hectares da quadrícula, ou seja $83,5 \%$ da área, são formados por terras com altitudes variando entre $500 \mathrm{~m}$ a $700 \mathrm{~m}$, representadas pela cor cinza e amarela no mapa.

As áreas que possuem altitudes na faixa dos $800 \mathrm{~m}$ a $1000 \mathrm{~m}$ representam apenas $1,2 \%$. Todavia, essas áreas merecem um cuidado especial quanto a seu uso, pois são muito suscetíveis à erosão, devido às condições de solo e de topografia. Essas áreas situam-se a sudeste da quadrícula, identificadas pela cor azul escura e vermelho. 
Tabela 3 - Classes de amplitude altimétrica (m) e suas respectivas áreas

\begin{tabular}{c|c|c}
\hline Amplitudes Altimétricas (m) & Áreas ( $\mathbf{h}$ a) & Porcentagem (\%) \\
\hline $400-500$ & 14640,2 & 5,1 \\
\hline $500-600$ & 145451,2 & 50,6 \\
\hline $600-700$ & 94527,8 & 32,9 \\
\hline $700-800$ & 28993,3 & 10,1 \\
\hline $800-900$ & 3158,0 & 1,1 \\
\hline $900-1000$ & 287,0 & 0,1 \\
\hline Total & $\mathbf{2 8 7 0 5 7 , 5}$ & $\mathbf{1 0 0 , 0}$
\end{tabular}

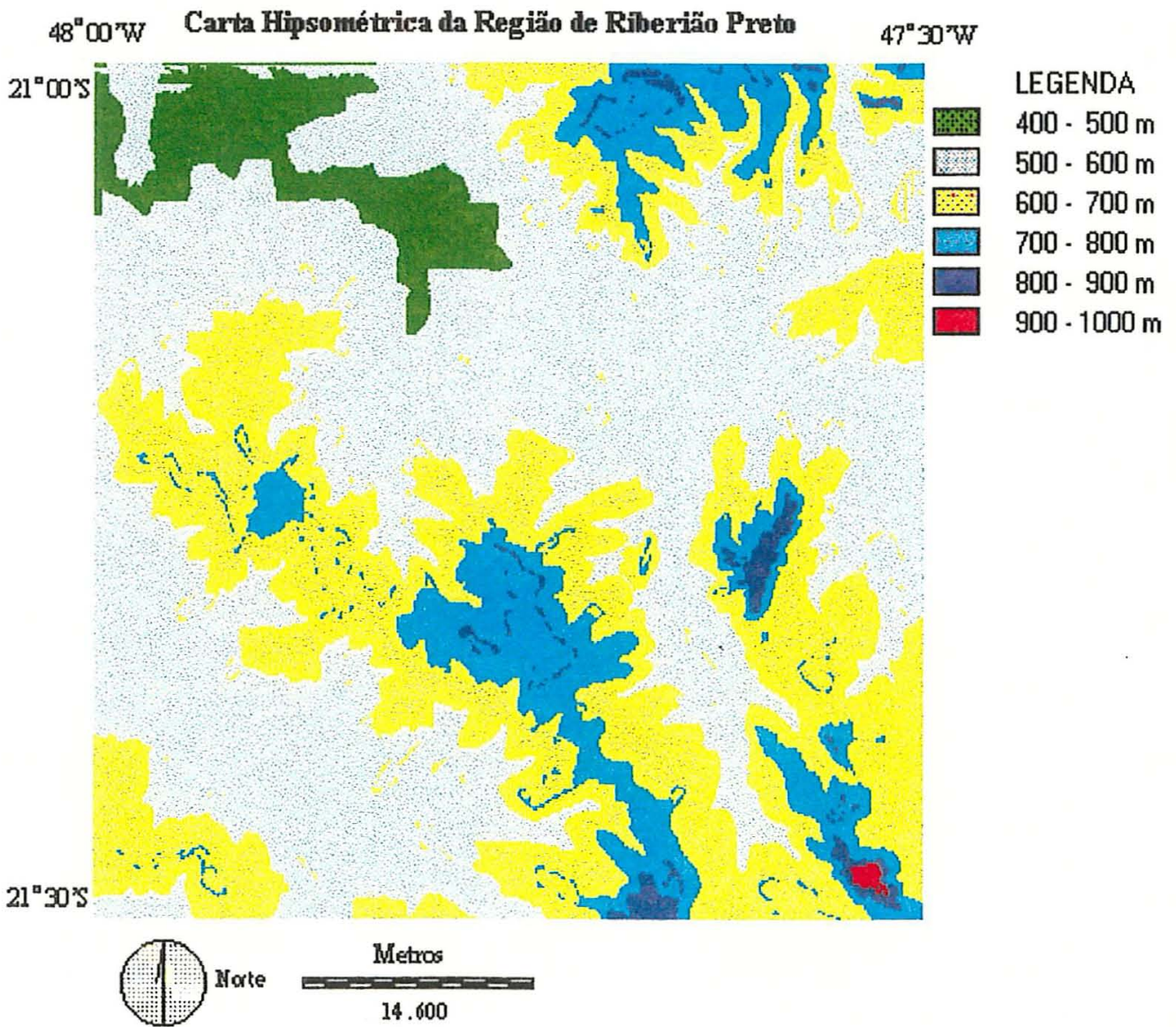

Figura 8 - Mapa de relevo da área de estudo 


\subsection{Clima}

\subsubsection{Temperatura do ar: dados mensais e anuais}

\subsubsection{Temperaturas máximas e mínimas mensais}

A Figura 9 ilustra a variação das temperaturas médias máximas e mínimas mensais para as localidades situadas na área de estudo.

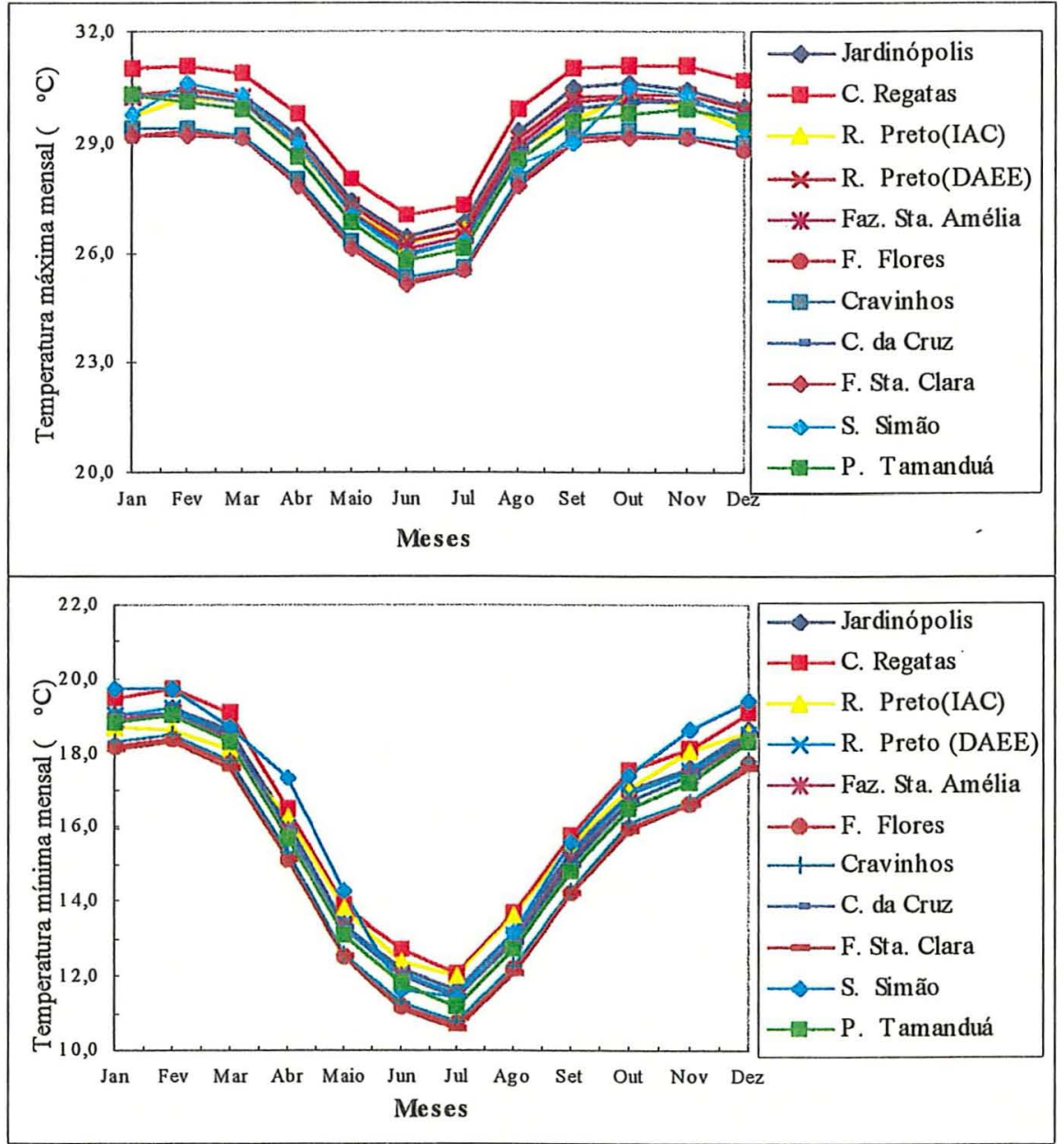

Figura 9 - Média mensal das temperaturas máximas e mínimas na área de estudo. 
Notou-se que existe grande aproximação entre as curvas, ficando evidente que a temperatura segue uma marcha de distribuição semelhante na região. Os maiores valores de temperaturas máximas ocorrem nas proximidades da localidade do Clube de Regatas, que está a 490 metros de altitude. Os menores valores médios de temperaturas mínimas foram observados nas localidades de Fazenda das Flores e Fazenda Santa Clara, que estão a $720 \mathrm{~m}$ de altitude, refletindo o efeito do relevo.

\subsubsection{Temperaturas médias}

Com referência aos dados de temperatura média, evidenciou-se que os maiores valores ocorreram na localidade do Clube de Regatas (Figura 10).

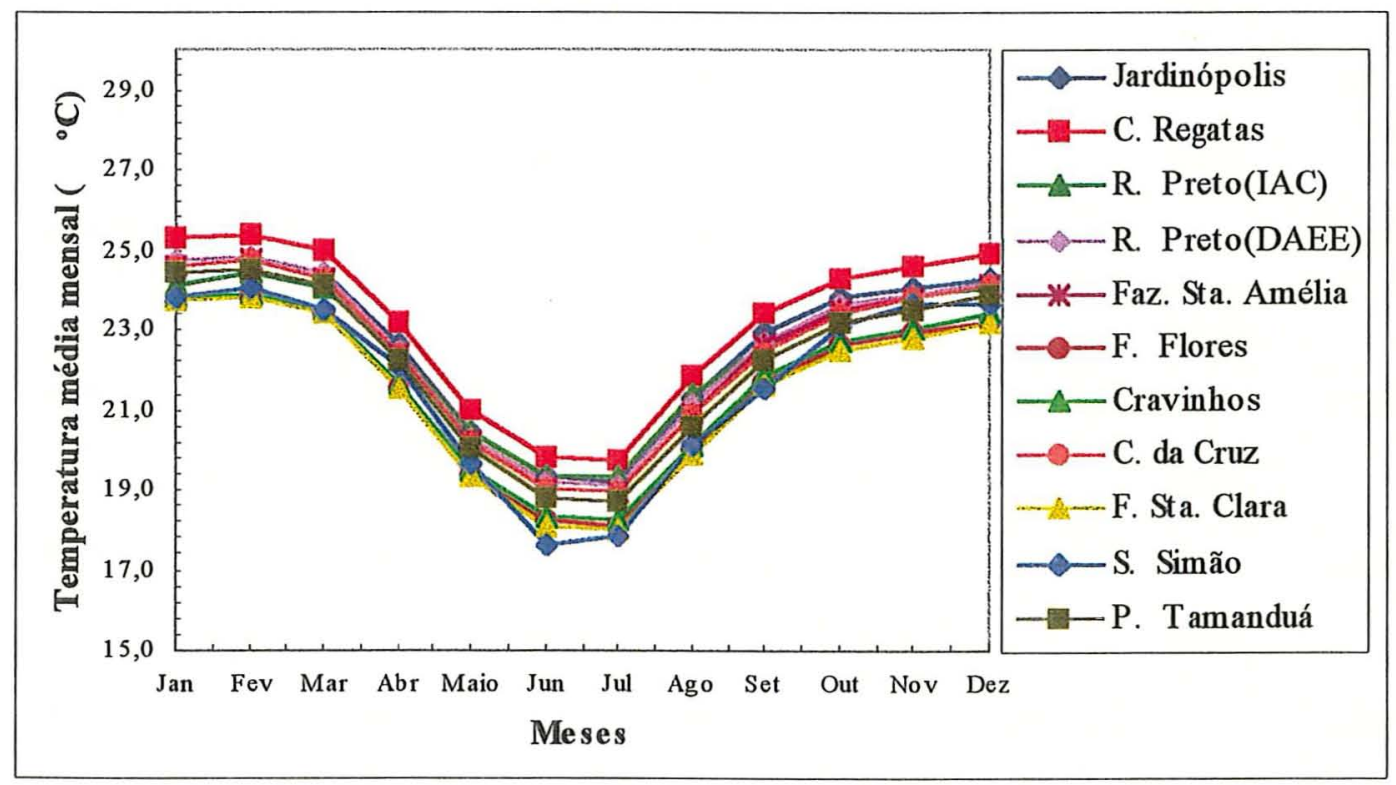

Figura 10 - Valores de temperatura média mensal na área de estudo.

Observou-se que fevereiro é o mês mais quente da região, com temperaturas médias variando de $23,8^{\circ} \mathrm{C}$ a $25,4^{\circ} \mathrm{C}$ (Anexo A). Em contrapartida, julho é o mês mais frio, 
com exceção na localidade de São Simão, que correspondeu ao mês de junho. Todavia, a diferença entre estes dois meses foi de apenas $0,2^{\circ} \mathrm{C}$, o que implica dizer que em média julho é o mês mais frio da região. Quando se avaliou a amplitude térmica média, ou seja a, diferença entre a temperatura média do mês mais quente e do mais frio, entre todas as localidades analisadas, encontrou-se a menor variação em Ribeirão Preto (IAC), da ordem de $5,1^{\circ} \mathrm{C}$, e a maior em São Simão, da ordem de $6,4^{\circ} \mathrm{C}$. Para efeito de planejamento, devese tomar por base que a amplitude térmica, na quadrícula, não ultrapassou os $7^{\circ} \mathrm{C}$.

Para uma maior elucidação da distribuição espacial da temperatura média anual, elaborou-se a Figura 11, onde é possivel visualizar que as áreas com temperaturas mais amenas, identificadas pela cor vermelha, estão situadas nas cercanias de Cravinhos e de Fazenda das Flores, localizados, praticamente a sudeste da quadrícula. As áreas sujeitas às maiores temperaturas localizam-se na parte norte-nordeste da área, englobando as localidades do Clube de Regatas e Jardinópolis, identificadas pela cor azul clara e azul escura, além de uma pequena área a sudoeste da quadrícula. Devido à pequena variação da altitude na quadrícula, a variabilidade espacial da temperatura média anual do ar não é acentuada, apresentando variações entre $21,0^{\circ} \mathrm{C}$ e $23,5^{\circ} \mathrm{C}$, com concentração na faixa de $21,5^{\circ} \mathrm{C}$ a $23,0^{\circ} \mathrm{C}$. 


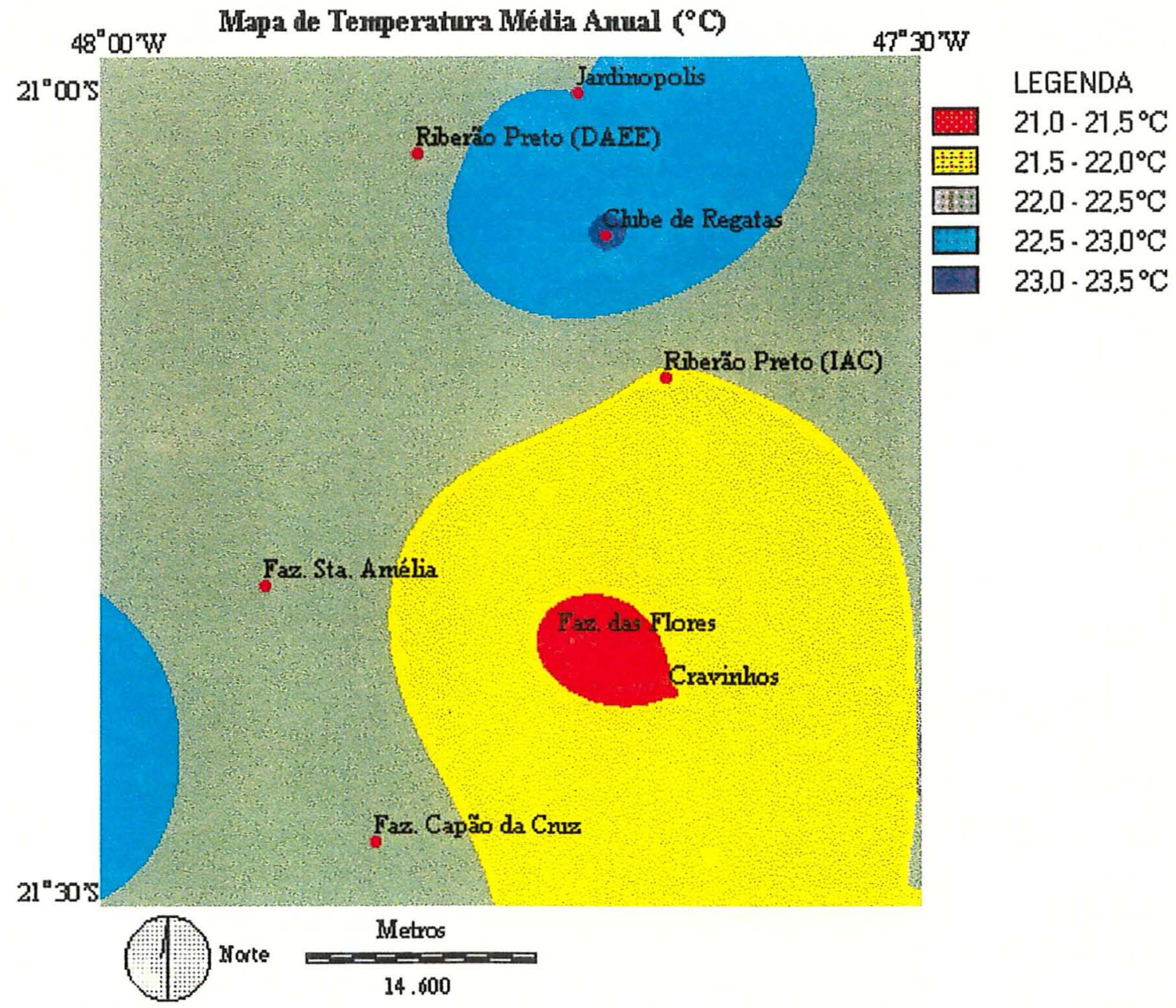

Figura 11 - Distribuição espacial das temperaturas médias na quadrícula 


\subsubsection{Temperatura do ar : dados diários de Ribeirão Preto}

Considerando-se a pequena variação espacial da temperatura do ar na quadrícula, procurou-se identificar a variação térmica, com base nos dados diários disponíveis, da localidade de Ribeirão Preto (IAC), tomando-os como representativos da região.

Verificou-se que o mês de outubro de 1985 foi o mais quente, chegando aos $33,5^{\circ} \mathrm{C}$ de temperatura máxima. Com relação ao mês mais frio, a menor temperatura mínima mensal foi de $7,9^{\circ} \mathrm{C}$, em julho de 1989.

Constatou-se que dentre os 30 anos analisados em Ribeirão Preto, a temperatura mínima absoluta diária foi de $-1,2^{\circ} \mathrm{C}$, ocorrida no dia 21 de julho de 1981 . Também foram verificados valores negativos nos dias $1 / 6 / 79 ; 26$ e $27 / 6 / 94$, da ordem de $-0,8^{\circ} \mathrm{C}$ e $-0,2^{\circ} \mathrm{C}$, respectivamente.

Os valores encontrados suscitaram a apresentação de uma carta (Figura 12) de distribuição das mínimas mensais, visando reforçar as informações quanto às possíveis limitações térmicas ao desenvolvimento das culturas, indicando áreas com maiores riscos de sofrerem prejuízos devidos às baixas temperaturas.

Observou-se que as mais baixas temperaturas ocorrem nas proximidades da Fazenda das Flores e Cravinhos, representadas pela cor azul escura. Essas localidades encontram-se com altitudes superiores a $700 \mathrm{~m}$, sendo um indício dessas temperaturas mais baixas na quadrícula.

A região compreendida pela cor rosa possui os maiores valores de temperaturas mínimas, nas proximidades do Clube de Regatas e Ribeirão Preto (IAC). Ressalta-se que segundo Camargo et al. (1993), na região de Ribeirão Preto, há probabilidade de ocorrência de temperaturas mínimas absolutas abaixo de $4^{\circ} \mathrm{C}$ em abrigo meteorológico, no mês de junho é de $28,5 \%$ e no mês de julho é de $36,6 \%$. 


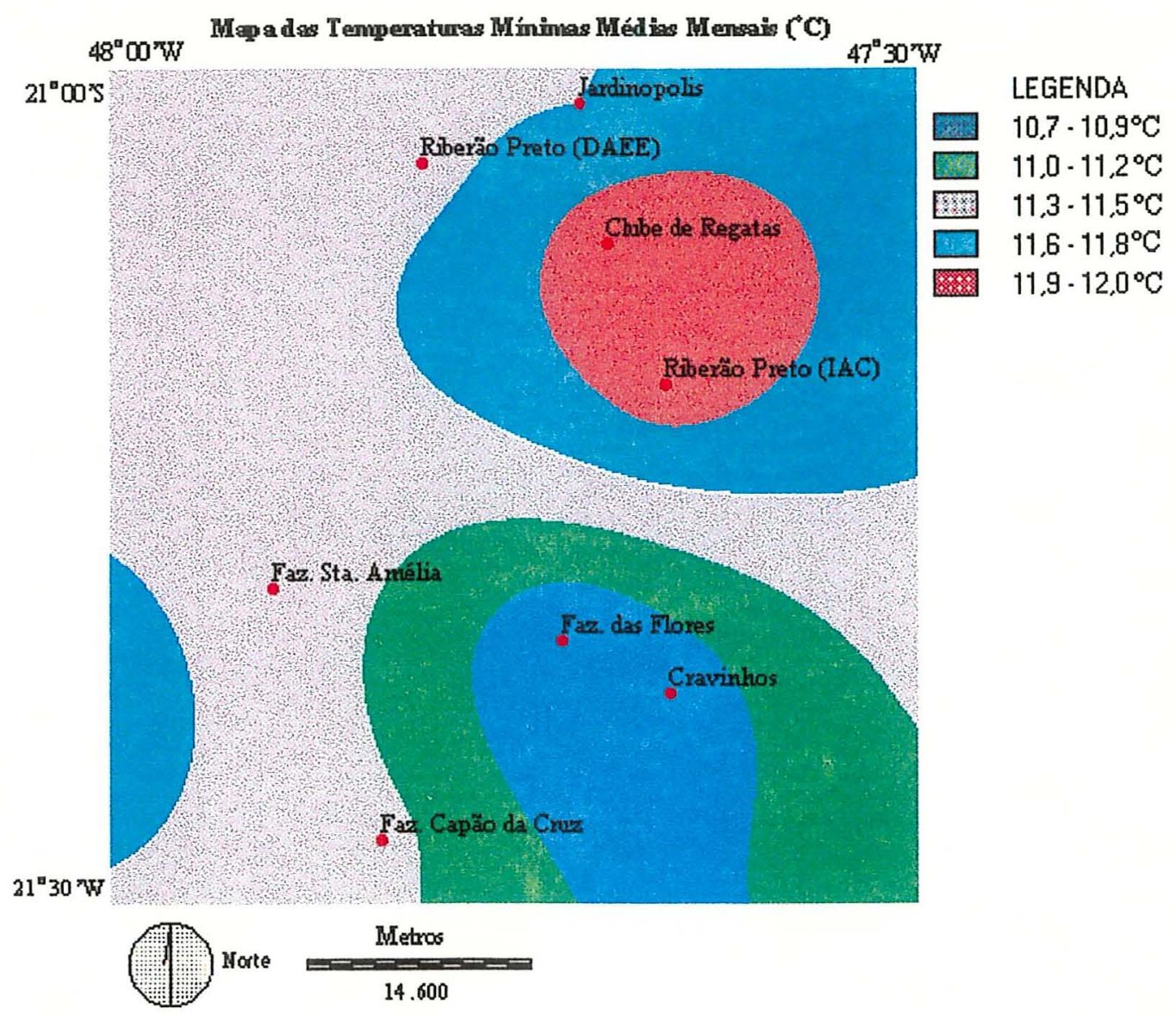

Figura 12 - Distribuição espacial das temperaturas mínimas médias mensais na quadrícula. 


\subsubsection{Chuvas mensais e anuais}

Os dados apresentados no Quadro 2, referem-se aos valores médios das chuvas mensais e anuais que ocorreram na quadrícula e nas localidades vizinhas a área de estudo.

Quadro 2 - Valores médios de alturas pluviometricas mensais e anuais referente às localidades situadas na quadrícula e localidades vizinhas.

\begin{tabular}{|c|c|c|c|c|c|c|c|c|c|c|c|c|c|c|}
\hline & Localidades & Jan & Fev & Mar & Abr & Maio & Jun & Jul & Ago & Set & Out & Vov & Dez & Anual \\
\hline \multirow{11}{*}{ 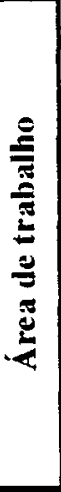 } & Jardinopolis & 257.5 & 225.7 & 169.1 & 111.4 & 66.3 & 25.8 & 28,1 & 24.8 & 77.5 & 157.8 & 186.2 & 309.8 & 1640.2 \\
\hline & C. de Regatas & 244.1 & 222.2 & 170.6 & 87.1 & 55.0 & 28.0 & 24.5 & 25.3 & 76.4 & 144.3 & 182.2 & 280.0 & 1539.7 \\
\hline & Riberrào Pretol: $A: 1$ & 240.9 & 221.1 & 162.5 & 92.7 & 64.4 & 32.9 & 31.8 & 33.3 & 68.5 & 130.5 & 174.3 & 268.7 & 1521.6 \\
\hline & Ruberăo Pretotasıl & 242.7 & 221.8 & 151.7 & 84.3 & 52.3 & 30.8 & 23.1 & 25.7 & 64.2 & 133.7 & 175.2 & 274.4 & 1479.8 \\
\hline & Faz. Sta. Amelia & 207.8 & 182.6 & 152.8 & 77.6 & 50.9 & 29.3 & 25.4 & 24.4 & 65.5 & 120.1 & 152.7 & 253.0 & 1342.1 \\
\hline & Fazdas Flores & 253.3 & 193.7 & 178.8 & 99.8 & 59.3 & 33.8 & 29.2 & 28.8 & 74.5 & 131.4 & 179.9 & 270.8 & 1533.3 \\
\hline & Cravunhos & 237.5 & 184.5 & 168.0 & 87.1 & 59.3 & 32.1 & 26.4 & 26.9 & 56.0 & 118.3 & 164.4 & 243.9 & 1402.5 \\
\hline & Capào da Cruz & 249.4 & 203.7 & 165.8 & 82.8 & 52.1 & 27.4 & 25.4 & 26.0 & 69.3 & 120.5 & 162.5 & 259.4 & 1444.2 \\
\hline & Faz. Sta. Clara & 260.6 & 203.1 & 176.3 & 93.9 & 60.8 & 34.0 & 29.1 & 29.2 & 76.8 & 138.8 & 178.6 & 269.0 & 1550.0 \\
\hline & São Simão & 245,5 & 172.6 & 155.4 & 84.3 & 77.1 & 31.1 & 27,6 & 28.2 & 69.3 & 127.9 & 182.9 & 264.5 & 1466.4 \\
\hline & P. do Tarrand ua & 273.5 & 230.6 & 161.2 & 86.5 & 55.7 & 34.0 & 28,4 & 31.2 & 72.8 & 138.8 & 179.9 & 266.2 & 1558.7 \\
\hline \multirow{11}{*}{ 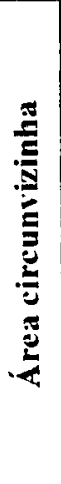 } & Luz Antôno & 248.2 & 213.3 & 170.8 & 87.0 & 59.1 & 33.5 & 30.4 & 23.4 & 71.0 & 139.0 & 196.3 & 265.3 & 1537.3 \\
\hline & L'sina Sta. Rita & 243.1 & 210.2 & 187.4 & 91.8 & 62.8 & 34.4 & 32.9 & 26.9 & 68.6 & 129.4 & 174.2 & 248.3 & 1510.0 \\
\hline & Faz. Cascata & 271.1 & 207.6 & 173.9 & 94.0 & 54.0 & 33.7 & 27.6 & 32.0 & 72.9 & 142.2 & 183.2 & 261.3 & 1553.4 \\
\hline & S.Rita do P. Quatro & 258.4 & 230.2 & 208.4 & 113.5 & 71.5 & 20.4 & 25,3 & 30.3 & 65.4 & 138.4 & 151.1 & 239.5 & 1552.3 \\
\hline & Bom Sucesso & 262.1 & 205.0 & 162.2 & 99.4 & 69.7 & 31.9 & 26.7 & 27.8 & 79.7 & 122.3 & 206.7 & 282.2 & 1575.7 \\
\hline & Faz. Mlournninos & 253.1 & 213.8 & 169.5 & 93.3 & 59.9 & 33.6 & 25.6 & 30.1 & 75.0 & 133.2 & 191.4 & 268.5 & $15+7.1$ \\
\hline & Faz. São Lorenco & 242.9 & 212.5 & 175.1 & 85.0 & 55.2 & $3+.3$ & 24.2 & 29.1 & 73.6 & 136.2 & 178.3 & 266.7 & 1513.0 \\
\hline & Faz Graciosa & 255.9 & 220.6 & 175.5 & 92.4 & 60.1 & 34.7 & 27.5 & 29.7 & 76.8 & 152.9 & 185.4 & 278.7 & 1590.2 \\
\hline & Sta.Cruz da Esperança & 258.7 & 219.9 & 185.7 & 110.3 & 64.0 & 30.1 & 21.7 & 26.0 & 78.0 & 154.4 & 186.6 & 280.8 & 1616.1 \\
\hline & Lage & 283.6 & 203.9 & 186.5 & 108.6 & 62.3 & 35.3 & 24.7 & 26.9 & 79.8 & 161.7 & 190.7 & 297.4 & 1661.2 \\
\hline & Pradopoles & 228.3 & 216.1 & 161.6 & 83.4 & 51.8 & 30.4 & 29.1 & 24.1 & 66.1 & 121.3 & 162.3 & 268.1 & $1+42.7$ \\
\hline
\end{tabular}

Na série estudada, observou-se que, em termos médios. o mês de dezembro é o mais chuvoso, seguido dos meses de janeiro e fevereiro. Nesse periodo, ocorreram os maiores eventos de chuvas mensais, com médias superiores a $200 \mathrm{~mm}$. Por outro lado, o mês de julho foi caracterizado como o menos chuvoso, apresentando médias inferiores a $32 \mathrm{~mm}$ (Quadro 2).

De acordo com Magalhães (1974), o regime de chuvas na região sudeste do Brasil é regulado pelas instabilidades tropicais (chuvas de convergência) e por Frentes Polares 
(chuvas frontais), além da maritimidade que torna as áreas litorâneas mais úmidas do que o planalto, e do relevo, que devido às chuvas orográficas, tornam as regiões de serras mais úmidas e pluviosas.

Analisando as chuvas em termos de total médio anual na área de estudo, observouse que os valores ficaram em torno dos $1500 \mathrm{~mm}$. O maior valor foi verificado na localidade de Jardinópolis, com 1640 mm, e o menor valor ocorreu na Fazenda Santa Amélia, contabilizando $1342 \mathrm{~mm}$. Nas localidades vizinhas, verificou-se que os valores também foram próximos aos $1500 \mathrm{~mm}$, sendo que a maior altura ocorreu na localidade de Laje, com $1661 \mathrm{~mm}$, e a menor, em Pradópolis, com valor de 1442 mm (Quadro 2).

A distribuição espacial das chuvas na quadrícula indica que as precipitações são mais abundantes ao nordeste da área, identificadas pelas cores azul clara, verde e azul escura. As chuvas vão diminuindo no sentido oeste, sendo as áreas menos chuvosas localizadas nas proximidades da Fazenda Santa Amélia (Figura 13).

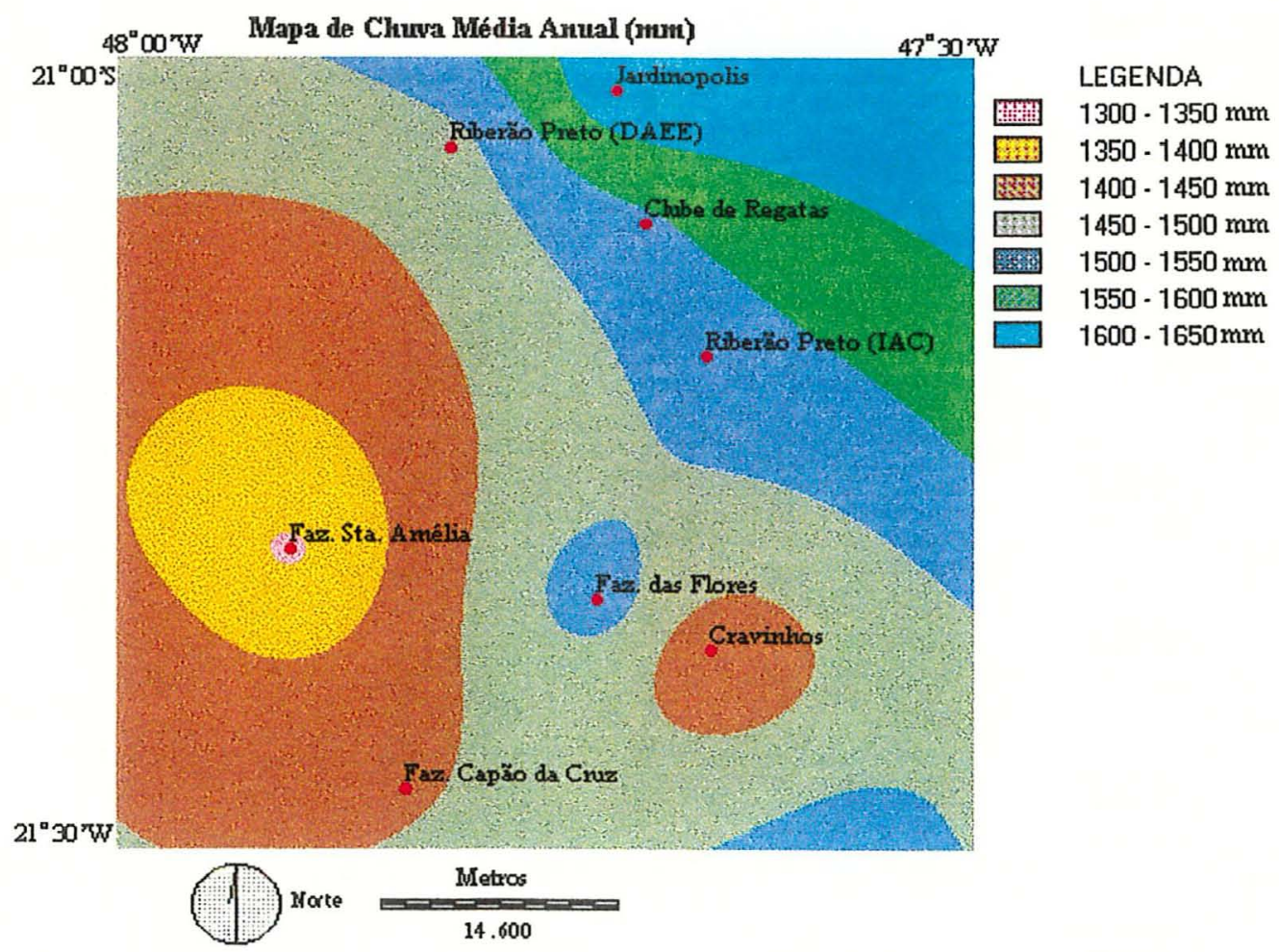

Figura 13 - Distribuição espacial das chuvas médias anuais, na área de estudo. 
Mesmo sendo a variação de relevo na quadrícula da ordem de 230 metros, os maiores valores de precipitação pluvial na direção mais a nordeste provavelmente sejam indicativos de um resíduo do efeito orográfico, pela elevação do relevo fora da área da quadrícula, com altitudes que chegam aproximadamente a $1000 \mathrm{~m}$, na divisa com Minas Gerais.

\subsubsection{Chuvas: dados diários de Ribeirão Preto}

\subsubsection{Chuvas em qüinqüídios}

Nos Anexos B e C, estão representados os valores de freqüências das alturas pluviométricas, em intervalos de cinco dias, para a localidade de Ribeirão Preto. Observou-se que nos meses de verão as chuvas contabilizaram totais qüinqüidiais variando de $5 \mathrm{~mm}$ até $195 \mathrm{~mm}$, sendo encontradas as maiores freqüências no intervalo de $5 \mathrm{~mm}$ a 45 $\mathrm{mm}$. Nos meses de outono, as maiores freqüências concentram-se no intervalo de $5 \mathrm{~mm}$ a $10 \mathrm{~mm}$. Para os meses de inverno, as maiores frequêencias desses totais nos qüinqüídios, praticamente não ultrapassaram os $5 \mathrm{~mm}$. Com relação aos meses referentes a primavera, notou-se que as chuvas vão se distribuindo ao longo do intervalo de $5 \mathrm{~mm}$ a $155 \mathrm{~mm}$ e as maiores freqüências concentram-se no intervalo de $5 \mathrm{~mm}$ a $10 \mathrm{~mm}$.

\subsubsection{Chuvas máximas diárias}

O conhecimento de eventos de chuvas máximas diárias está intimamente relacionado a aplicações nas mais diversas áreas de interesse, tais como: dimensionamento de canais e vertedouros; irrigação e drenagem; conservação dos solos; descarga e galerias de águas pluviais; aproveitamento de bacias hidrográficas, pavimentação de rodovias e estradas; planejamento de aeroportos, entre outros. 
Dentro desse enfoque, procurou-se identificar em cada mês os eventos extremos, em 24 horas, ocorridos em Ribeirão Preto durante os 30 anos analisados (Figura 14).

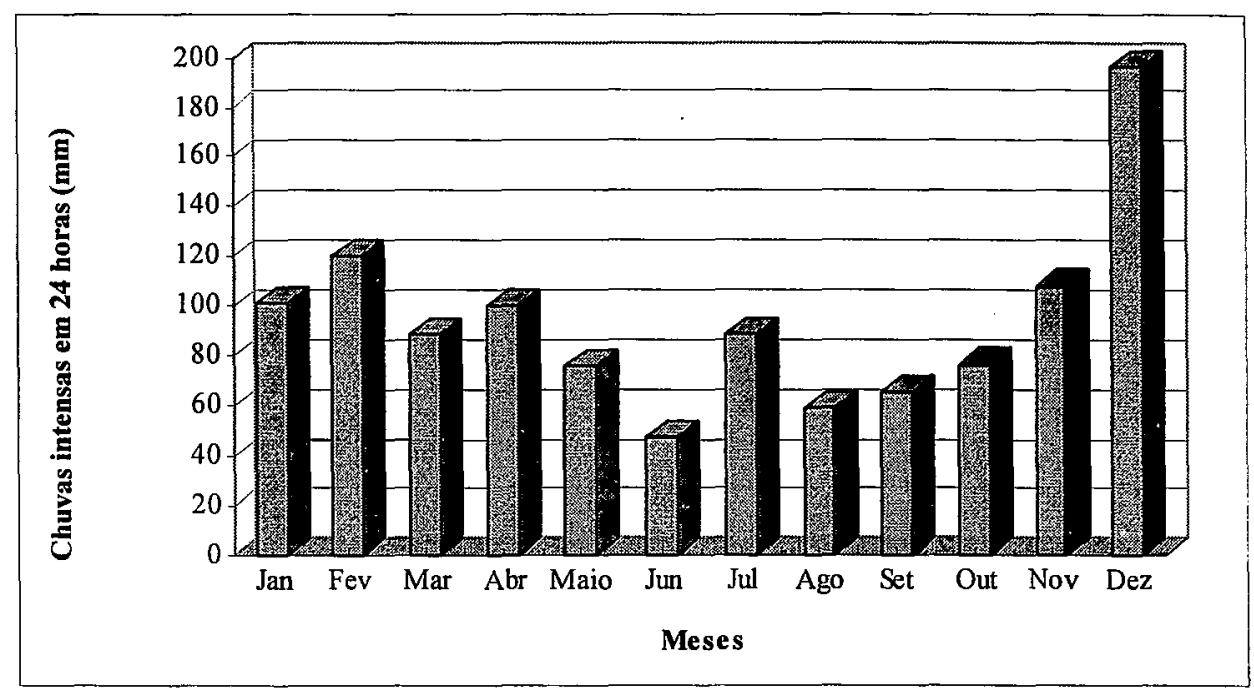

Figura 14 - Chuvas Máximas em 24 horas em cada mês, ocorridas no período de 1967 a 1996 em Ribeirão Preto, SP.

O maior evento ocorreu no dia $26 / 12 / 86$, totalizando $196,3 \mathrm{~mm}$. A chuva do dia 5/02/93 foi a segunda maior, da série de dados analisados, com $120 \mathrm{~mm}$. Verificou-se que podem ocorrer chuvas superiores a $89 \mathrm{~mm}$, em um dia, no período compreendido entre os meses de novembro a abril.

Conforme Cabeda (1977), todas as chuvas individuais que apresentam $10 \mathrm{~mm}$ ou mais de precipitação total e aquelas com menos de $10 \mathrm{~mm}$, se a quantidade for igual ou maior que $6 \mathrm{~mm}$ em um período de quinze minutos, são consideradas erosivas. Após a análise das intensidades, constatou-se que entre as chuvas máximas, as com maior potencial erosivo do solo ocorreram no dia 19/04/77, com intensidade de $56,6 \mathrm{~mm}$. hora $^{-1}$ e no dia 26/12/86, com 17,2 mm . hora ${ }^{-1}$.

$\mathrm{Na}$ Tabela 4, estão representadas as estimativas de probabilidades de ocorrências de chuvas máximas em 24 horas, na localidade de Ribeirão Preto (IAC). 
Tabela 4 - Freqüência $(f)$ e probabilidade $P(X)$ em porcentagem de ocorrência de chuvas máxima em 24 horas, igual ou menor do que o valor médio (PM), em Ribeirão Preto, SP.

\begin{tabular}{|c|c|c|c|c|c|c|c|c|c|c|c|}
\hline \multicolumn{12}{|c|}{ Verão } \\
\hline \multicolumn{4}{|c|}{ Dez } & \multicolumn{4}{|c|}{ Jan } & \multicolumn{4}{|c|}{ Fev } \\
\hline Classes & P.M & $\mathrm{t}$ & $P(X)<=\left(0_{0}\right)$ & Classes & $\mathrm{PM}$ & $\mathrm{f}$ & $\mathrm{P}(\mathrm{X}) \mathrm{K}=\left({ }^{\circ} \%\right)$ & Classes & PM & $f$ & $\mathrm{P}(\mathrm{X})<=(\boldsymbol{0}, \mathbf{0})$ \\
\hline $11-42$ & 26.5 & 11 & 27.8 & $11-26$ & 18.5 & 1 & 7.3 & $11-29$ & 20 & 5 & 16.4 \\
\hline $42-73$ & 57.5 & 9 & 70.2 & $26-41$ & 33,5 & 6 & 31.6 & $29-47$ & 38 & 7 & 45.9 \\
\hline $73-104$ & 88.5 & 7 & 90,7 & $41-56$ & 48.5 & 11 & 60.2 & $47-65$ & 56 & 10 & 71.5 \\
\hline $104-135$ & 119.5 & 2 & 97.3 & $56-71$ & 63.5 & 6 & 79.9 & $65-83$ & 74 & 3 & 86.5 \\
\hline $135-166$ & 150.5 & 0 & 99.3 & $71-86$ & 78.5 & 4 & 90.6 & $83-101$ & 92 & 4 & 93.9 \\
\hline $166-197$ & 181.5 & 1 & 99.8 & $86-101$ & 93.5 & 2 & 95.7 & $101-119$ & 110 & 1 & 97.3 \\
\hline-200 & & 30 & 99.8 & 200 & & 30 & 100.0 & $\therefore 150$ & & 30 & 99.4 \\
\hline \multicolumn{12}{|c|}{ Outono } \\
\hline \multicolumn{4}{|c|}{ Mar } & \multicolumn{4}{|c|}{$\mathrm{Abr}$} & \multicolumn{4}{|c|}{ Maio } \\
\hline Classes & $\mathrm{PM}$ & $\mathrm{f}$ & $P(X)<=\left({ }^{\circ} 0\right)$ & Classes & $\mathrm{PM}$ & $\mathrm{f}$ & $\mathrm{P}(\mathrm{X})<=(\%)$ & Classes & $\mathrm{PM}$ & $\mathrm{f}$ & $\mathrm{P}(\mathrm{X})<=(\%)$ \\
\hline $3 \cdot 17$ & 10 & 3 & 11.0 & $2 \cdot 18$ & 10 & 10 & 24.9 & $0-13$ & 6.5 & 10 & 29.3 \\
\hline $17-31$ & 24 & 8 & 39.5 & $18-34$ & 26 & 8 & 59.1 & $13-26$ & 19.5 & 6 & 59.8 \\
\hline $31-45$ & 38 & 9 & 67.6 & $34-50$ & 42 & 5 & 82.0 & $26-39$ & 32.5 & 9 & 80.6 \\
\hline $45-59$ & 52 & 5 & 84.8 & $50-66$ & 58 & 4 & 92.8 & $39-52$ & 45.5 & 2 & 91.4 \\
\hline $59-73$ & 66 & 4 & 93,3 & $66-82$ & 74 & 2 & 97.2 & $52-64$ & 58 & 2 & 96.0 \\
\hline $73-87$ & 80 & 1 & 97.1 & $82-98$ & 90 & 0 & 98.9 & $64-76$ & 70 & 1 & 98.2 \\
\hline 100 & & 30 & 98.7 & $98-114$ & 106 & 1 & 99.6 & & & 30 & \\
\hline-150 & & & 99.9 & & & 30 & & & & & \\
\hline \multicolumn{12}{|c|}{ Inverno } \\
\hline \multicolumn{4}{|c|}{ Jun } & \multicolumn{4}{|c|}{ Jul } & \multicolumn{4}{|c|}{ Ago } \\
\hline Classes & P.I & $\mathrm{f}$ & $P(X)<=\left(0^{0} 0\right)$ & Classes & $\mathrm{PM}$ & i & $\mathrm{P}(\mathrm{X})<=\left({ }^{0} 0\right)$ & Classes & $\mathrm{PM}$ & $\mathrm{t}$ & $P(X)<=\left(0^{\circ}\right)$ \\
\hline 0.8 & 4 & 12 & 36.4 & $0-15$ & 7.5 & 19 & 58.1 & $0-10$ & 5 & 18 & 53.2 \\
\hline $8-16$ & 12 & 8 & 61.9 & $15-30$ & 22.5 & 7 & 87.1 & $10-20$ & 15 & 7 & 81.4 \\
\hline $16-24$ & 20 & 2 & 79.6 & $30-45$ & 37.5 & 2 & 96.6 & $20-30$ & 25 & 2 & 93.5 \\
\hline $24-32$ & 28 & 3 & 89.7 & $+5-60$ & $\$ 2.5$ & 0 & 99.1 & $30-40$ & 35 & 1 & 97.8 \\
\hline $32-40$ & 36 & 2 & 95.0 & $60-75$ & 67.5 & 1 & 99.8 & $40-50$ & 45 & 0 & 99.3 \\
\hline $40-48$ & 44 & 3 & 97.6 & 75.90 & 82.5 & 1 & 99.9 & $50-60$ & 55 & 2 & 99.8 \\
\hline 150 & & 30 & 100.0 & 100 & & 30 & 100.0 & 80 & & 30 & 100.0 \\
\hline \multicolumn{12}{|c|}{ Primavera } \\
\hline \multicolumn{4}{|c|}{ St } & \multicolumn{4}{|c|}{ Out } & \multicolumn{4}{|c|}{ Nov } \\
\hline Classes & PM & $\mathrm{t}$ & $P(X)<=(\%)$ & Classes & $\mathrm{PM}$ & $\mathrm{f}$ & $\mathrm{P}(\mathrm{X})<=\left({ }^{\circ}, 0\right)$ & Classes & PM & $\mathrm{t}$ & $P(X)<=(\%)$ \\
\hline $1-12$ & 6.5 & 7 & 23.4 & $12 \cdot 23$ & 17.5 & 3 & 11.2 & $12 \cdot 28$ & 20 & 5 & 19.4 \\
\hline $12-23$ & 17.5 & 10 & 53.3 & $23-34$ & 28.5 & 8 & 36.1 & $28-44$ & 36 & 8 & 47.8 \\
\hline $23 \cdot 34$ & 28.5 & 5 & 76.2 & $34 \cdot 45$ & 39.5 & 8 & 62.1 & 44.60 & 52 & 8 & 71.8 \\
\hline $34-45$ & 39.5 & 4 & 88.9 & $45-56$ & 50,5 & 3 & 80.1 & $60-76$ & 68 & + & 86.1 \\
\hline $45 \cdot 56$ & 50.5 & 3 & 95.0 & $56-67$ & 61.5 & 4 & 90.1 & $76-92$ & 84 & 1 & 93.5 \\
\hline 56.67 & 61.5 & 1 & 97.8 & $67-78$ & 72.5 & 4 & 95.3 & $92-108$ & 100 & 4 & 97.0 \\
\hline 80 & & 30 & 99.2 & 100 & & 30 & 99.0 & 150 & & 30 & 99.6 \\
\hline
\end{tabular}


Em Ribeirão Preto, após a análise das probabilidades dos eventos extremos, analisadas individualmente, constatou-se que nos meses de verão existe uma probabilidade de $9 \%$ das chuvas máximas em dezembro serem superiores a $104 \mathrm{~mm}$. $\mathrm{dia}^{-1}$ (tempo de recorrência de 11 anos). Em janeiro e fevereiro, em média a probabilidade das chuvas máximas serem superiores a $83 \mathrm{~mm} \cdot \mathrm{dia}^{-1}$, situa-se em torno de $11,4 \%$. No outono, as máximas chuvas não ultrapassaram os $66 \mathrm{~mm}$. dia ${ }^{-1}$, nos meses de março e abril com 7\% de probabilidade e no mês de maio, essa probabilidade não superou os $2 \%$. É nesta estação que existe a maior probabilidade de ocorrência de chuvas máximas em 24 horas, resultado este semelhante ao encontrado para Piracicaba por Piccinini \& Angelocci (1997).

Nos meses de inverno, em média, $90 \%$ das chuvas máximas não ultrapassaram aos $30 \mathrm{~mm}$. $\mathrm{dia}^{-1}$. Com a chegada da primavera os eventos extremos se distribuíram aleatoriamente, ficando cerca de $91 \%$ das alturas pluviométricas abaixo dos $60 \mathrm{~mm}$.dia ${ }^{-1}$. Vieira et al. (1991) observaram que a região de Ribeirão Preto possui isoietas variando entre $95 \mathrm{~mm}$. dia ${ }^{-1}$ e $100 \mathrm{~mm}$. dia ${ }^{-1}$, para um período de retorno de 5 anos. Para um período de retorno de 10 anos, as chuvas máximas diárias prováveis estão em torno dos $110 \mathrm{~mm} \cdot \mathrm{dia}^{-1}$.

Apesar da boa representatividade da localidade de Ribeirão Preto (IAC) quanto ao clima da quadrícula, deve-se ressaltar que a disponibilidade de dados diários nas outras localidades permitiria uma melhor caracterização espaço-temporal dessas chuvas máximas. 


\subsubsection{Balanco hídrico}

Na Tabela 5 estão representados os valores dos parâmetros do balanço hídrico normal para 11 localidades, pertencentes à quadrícula estudada.

Tabela 5 - Valores anuais. em milimetros. de Evapotranspiração Potencial - EP. Precipitação Pluvial - P. Evapotranspiração Real - ER Deficiência Hídrica - DEF. Excedente Hídrico - EXC

\begin{tabular}{l|c|c|c|c|c}
\hline \multicolumn{1}{c|}{ Localidades } & EP & P & ER & DEF & EXC \\
\hline Jardinópolis & 1118 & 1640 & 1072 & 46 & 567 \\
\hline Clube de Regatas & 1176 & 1538 & 1109 & 66 & 428 \\
\hline Ribeirão Preto(IAC) & 1097 & 1521 & 1057 & 40 & 464 \\
\hline Ribeirão Preto(DAEE) & 1109 & 1480 & 1049 & 60 & 430 \\
\hline Faz Sta. Amélia & 1098 & 1342 & 1036 & 62 & 305 \\
\hline Faz.das Flores & 1022 & 1534 & 997 & 25 & 536 \\
\hline Cravinhos & 1032 & 1404 & 990 & 41 & 414 \\
\hline Capão da Cruz & 1097 & 1444 & 1042 & 54 & 401 \\
\hline Faz Sta. Clara & 1019 & 1551 & 996 & 22 & 554 \\
\hline São Simão & 1040 & 1466 & 1014 & 25 & 451 \\
\hline P. do Tamanduá & 1076 & 1559 & 1042 & 34 & 516 \\
\hline
\end{tabular}

De posse dos resultados dos balanços hídricos climatológicos, observou-se que existe excedente hídrico no periodo compreendido entre os meses de novembro a março, para uma capacidade maxima de água disponivel igual à 100mm (Anexo D). Nesses meses, ocorre o pleno armazenamento de água no solo, possibilitando as culturas evapotranspirarem potencialmente. Portanto, esse periodo é o mais propício às culturas anuais, devido à maior eficiència de utilização de águas pluviais.

Vale salientar que a irrigação não foi considerada no julgamento quanto ao grau de limitação do fator deficiència hídrica. Assim, o período de melhor oferta pluviométrica corresponde aos meses de outubro a março.

$\mathrm{O}$ ritmo da disponibilidade hídrica seguiu o das chuvas. Nos meses de janeiro a abril, seguidos de novembro e dezembro, a precipitação pluvial é superior à evapotranspiração potencial, ocorrendo, nesse periodo, excedente hídrico. O total de excedente, em todas as localidades, superou os $300 \mathrm{~mm}$ (Tabela 5). 
Nos meses de junho a setembro o solo começa a perder água, acarretando valores de P - EP negativos e os valores de ER são menores que os de EP. Nesse período, os valores de evapotranspiração real são superiores aos de precipitação pluvial.

Observando-se a distribuição espacial da deficiência hídrica anual na região, verificou-se que a maior parte da área se enquadra na faixa dos $30 \mathrm{~mm}$ a $60 \mathrm{~mm}$, representados pela cor azul (Figura 15). Em média, a deficiência ocorre nos meses de junho a setembro. As áreas com maior deficiência hídrica localizam-se nas proximidades do Clube de Regatas, o qual totalizou o maior valor de deficiência anual da ordem de 66 mm e estão identificadas pela cor amarela.

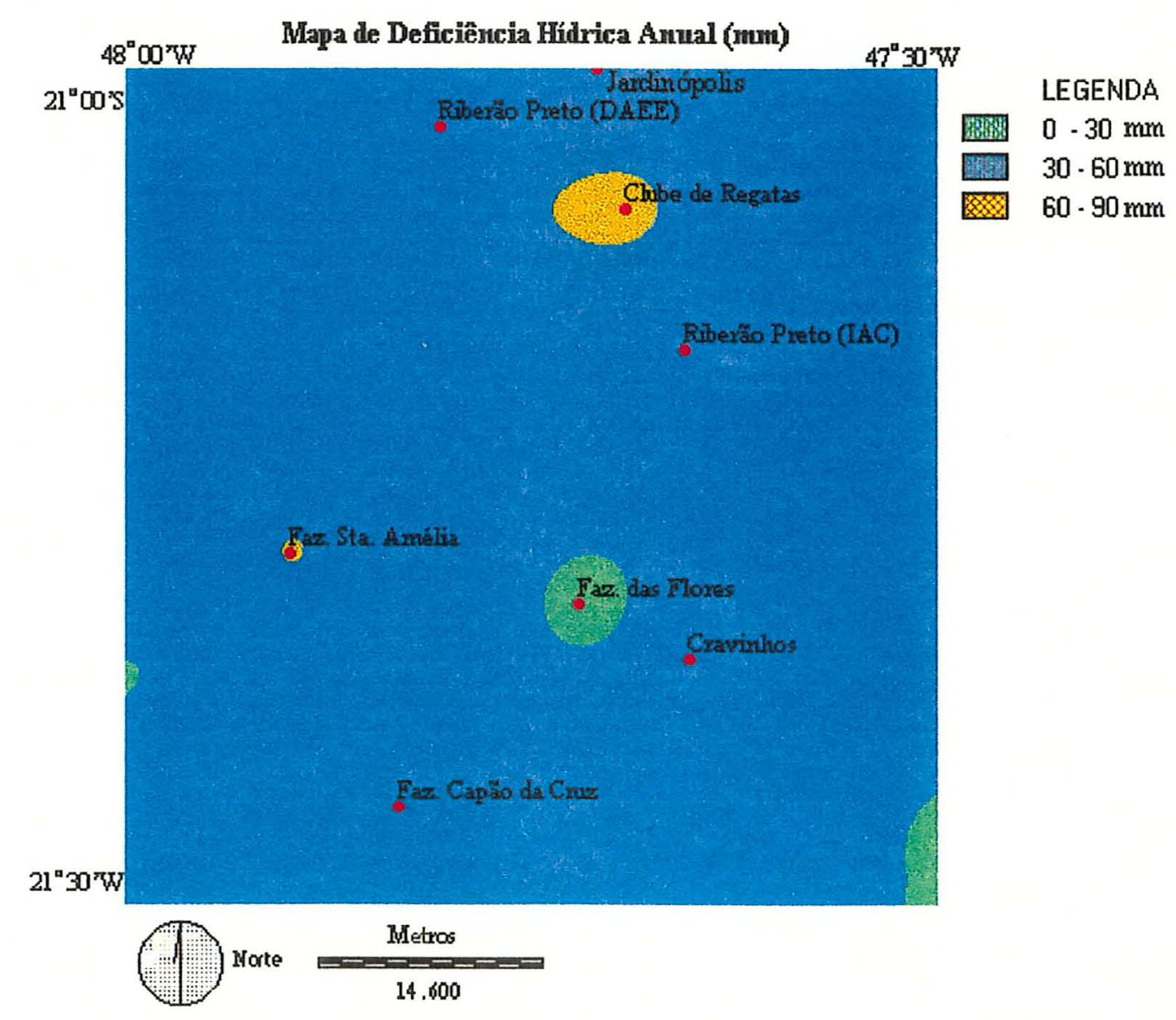

Figura 15 - Mapa de deficiência hídrica anual da Região de Ribeirão Preto, SP 
Comparando esse período em que ocorrem déficits na área de estudo com os critérios preconizados por Ramalho Filho (1995), verificou-se que, dominantemente, a área possui restrições moderadas em termos de deficiência hídrica, no periodo compreendido entre junho a setembro (Quadro 5).

Pelos critérios assumidos neste trabalho, observou-se que existiram localidades com os mesmos 4 meses de deficiência hídrica, no entanto enquadraram-se em classes diferentes. Ou seja, por exemplo, na Fazenda das Flores a deficiência hídrica anual pode representar até $15 \%$ da evapotranspiração potencial - ETP, no período seco (pouca deficiência). Em Prainha do Tamanduá, Jardinópolis e Ribeirão Preto (IAC) a deficiência foi enquadrada como moderada, pois pode representar de $15 \%$ a $30 \%$ da ETP no período seco. Já no clube de Regatas e Fazenda Santa Amélia a deficiência hídrica foi enquadrada como acentuada pois, pode representar entre $30 \%$ a $45 \%$ da ETP no período seco.

Quadro 5 - Valores de deficiências hídricas anuais comparados aos graus de limitação desse fator adotados por Ramaho Filho (1995).

\begin{tabular}{|c|c|c|c|c|c|c|}
\hline & No. & LOCALIDADES & Alt.m) & DEF (mm) & P. DEF & G. de limit ação \\
\hline \multirow{11}{*}{$\begin{array}{l}9 \\
\\
0 \\
0 \\
0 \\
0 \\
0 \\
0 \\
0\end{array}$} & 1 & Jardinopolis & 580 & 46 & $\mathrm{~J}-\mathrm{J}-\mathrm{A}-\mathrm{S}$ & $\mathbf{M}$ \\
\hline & 2 & Clube de Regatas & 490 & 66 & $J-J-A-S$ & $\mathbf{M}$ \\
\hline & 3 & Ribeirão Preto & 621 & 37 & $J-J-A-S$ & $\mathbf{M}$ \\
\hline & 4 & Ribeirāo Preto & 580 & 60 & $J=J-A-S$ & $\mathbf{M}$ \\
\hline & 5 & Faz. S. Amélia & 590 & 62 & M-J-J-A-S & $\mathbf{M}$ \\
\hline & 6 & Faz. das Flores & 720 & 25 & J-J.A.S & $\mathbf{M}$ \\
\hline & 7 & Cravinhos & 700 & 42 & $J \cdot J \cdot A-S$ & $\mathbf{M}$ \\
\hline & 8 & Capão da Cruz & 580 & 54 & $J \cdot J \cdot A \cdot S$ & $\mathbf{M}$ \\
\hline & 9 & Faz. Sa. Clara & 720 & 22 & $J-A-S$ & $\mathbf{L}$ \\
\hline & 10 & São Simāo & 618 & 25 & $J-A-S$ & $\mathbf{L}$ \\
\hline & 11 & Prainha do $T$ amanduá & 610 & 34 & $J-J-A-S$ & $M$ \\
\hline \multicolumn{7}{|c|}{ 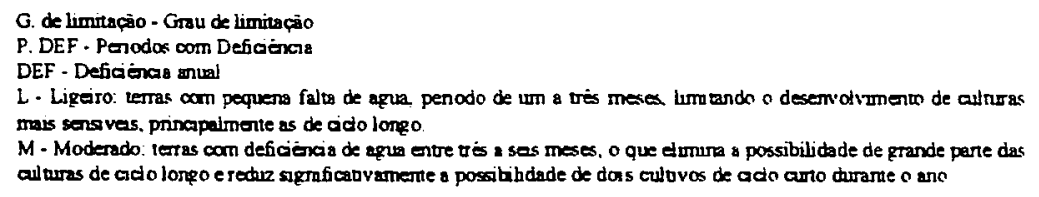 } \\
\hline
\end{tabular}




\subsubsection{Tipologia climática}

A região acha-se regida em sua maior parte pelo subtipo Aw, da classificação de Köppen (1918), denominado de tropical úmido com temperatura média do mès mais frio superior a $18^{\circ} \mathrm{C}$, inverno seco e precipitação média do mês mais seco inferior a 60 $\mathrm{mm}$. Na localidade de São Simão, o subtipo climático é o Cwa, considerado como temperado, sendo a temperatura média do mês mais frio inferior a $18^{\circ} \mathrm{C}$ e a temperatura média do mês mais quente superior a $22^{\circ} \mathrm{C}$. Salienta-se contudo, que na série de dados analisados não encontrou-se o subtipo Cwb, citado por Oliveira \& Prado (1987).

A partir dos resultados dos balanços hídricos, foi possivel identificar 3 subtipos climáticos conforme a classificação de Thornthwaite (1948). A localidade do Clube de Regatas pertence ao tipo $\mathbf{B}_{1} \mathbf{r} \mathbf{A}_{4}^{\prime} \mathbf{a}^{\prime}$ considerado como clima úmido com pequena deficiência hídrica e pouca variação da temperatura durante o ano, sendo portanto megatérmico e as plantas crescem o ano todo. As demais localidades acham-se regidas pelos tipos $\mathbf{B}_{1} \mathbf{r} \mathbf{B}_{+}{ }_{4} \mathbf{a}^{\prime}, \mathbf{B}_{2} \mathbf{r} \mathbf{B}_{4}{ }_{4} \mathbf{a}^{\prime}$, que se caracterizam por apresentarem clima úmido com pequena deficiência hídrica, mesotérmico, com $75 \%$ da estação de crescimento concentrada no verão. Na Figura 16, nota-se bem a gradação entre esses tipos climáticos, sendo a maior área regida pela tipologia $\mathbf{B}_{1} \mathbf{r} \mathbf{B}^{\prime}{ }_{+} \mathbf{a}^{\prime}$, delimitada pela cor azul. 


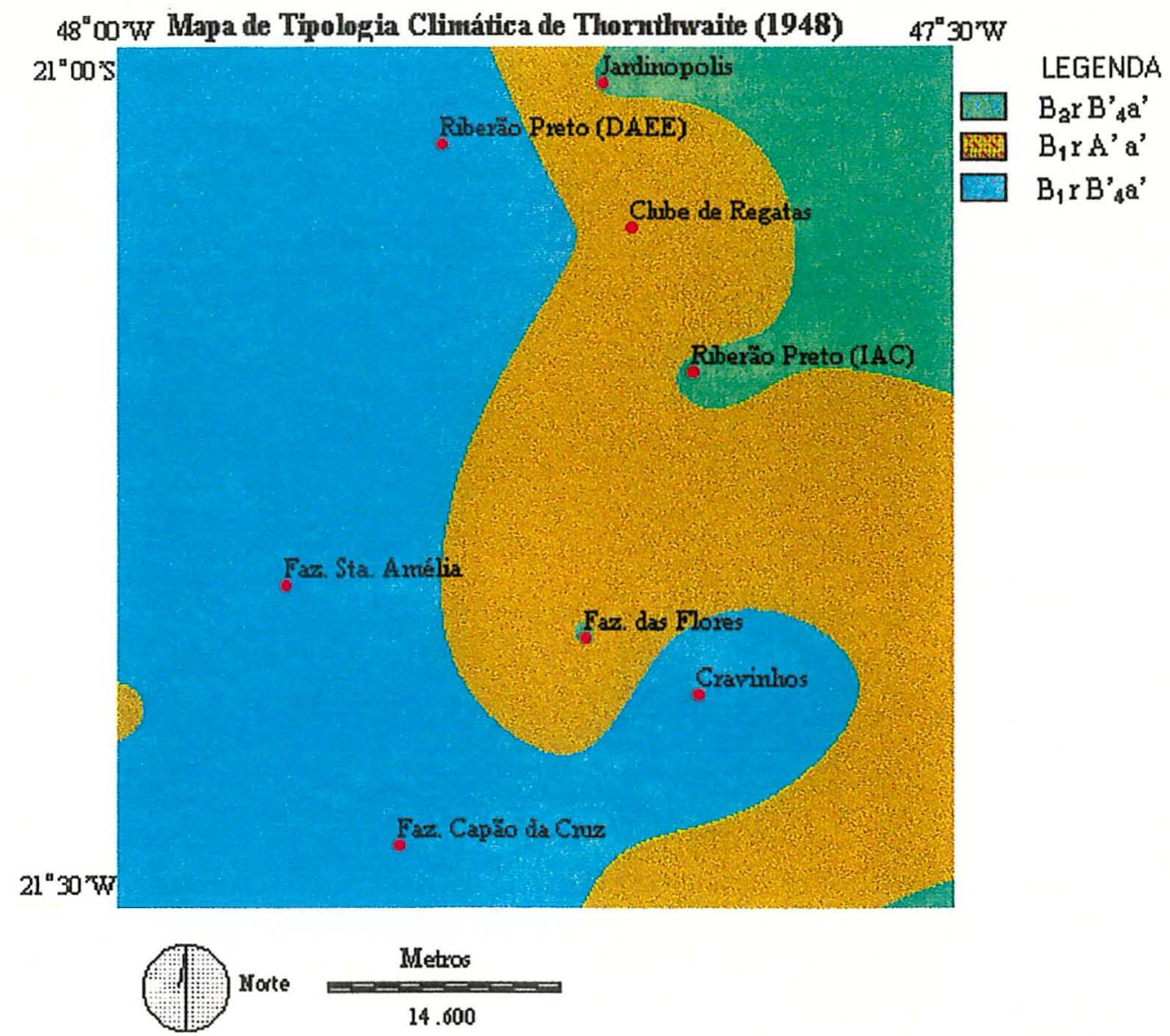

Figura 16 - Mapa de tipologia climática segundo Thornthwaite (1948).

\subsection{Zoneamento agroecológico}

O produto de integração dos Planos de Informação de solos, relevo e deficiência hídrica, resultaram na obtenção do mapa de zoneamento agroecológico da quadrícula.

Em sua maior parte, verificou-se que, das limitações impostas pelo clima, passou a ter maior peso o fator deficiência hídrica do solo, haja vista a área apresentar uma quase uniformidade no regime térmico-hídrico.

Assim, as limitações impostas pelos fatores quanto aos solos e ao relevo, passaram a ter um maior peso na seleção de áreas destinadas à conservação ambiental. As zonas agroecológicas são decorrentes das coincidências entre as características dessas variáveis ambientais. 
O mapa gerado após o cruzamento dos Planos de Informação (Figura 17), possibilitou a indicação de 6 tipos de uso planejado da terra. As áreas representadas com a cor verde clara apresentam indicações quanto ao potencial de uso com agricultura intensiva (arroz, milho, feijão, cana-de-açúcar e amendoim). Na cor azul clara, estão indicadas as áreas recomendadas para agricultura extensiva (café e cítros). Na cor amarela, estão representadas as áreas que podem ser utilizadas com agricultura (III), por exemplo: as olerícolas. Recomendadas para Pecuária estão as áreas identificadas pela cor verde escura. As áreas zoneadas com a cor azul escura e vermelha devem ser utilizadas com um certo cuidado, por pertencerem a ecossistemas frágeis, sendo indicadas para agrossilvicultura e preservação.

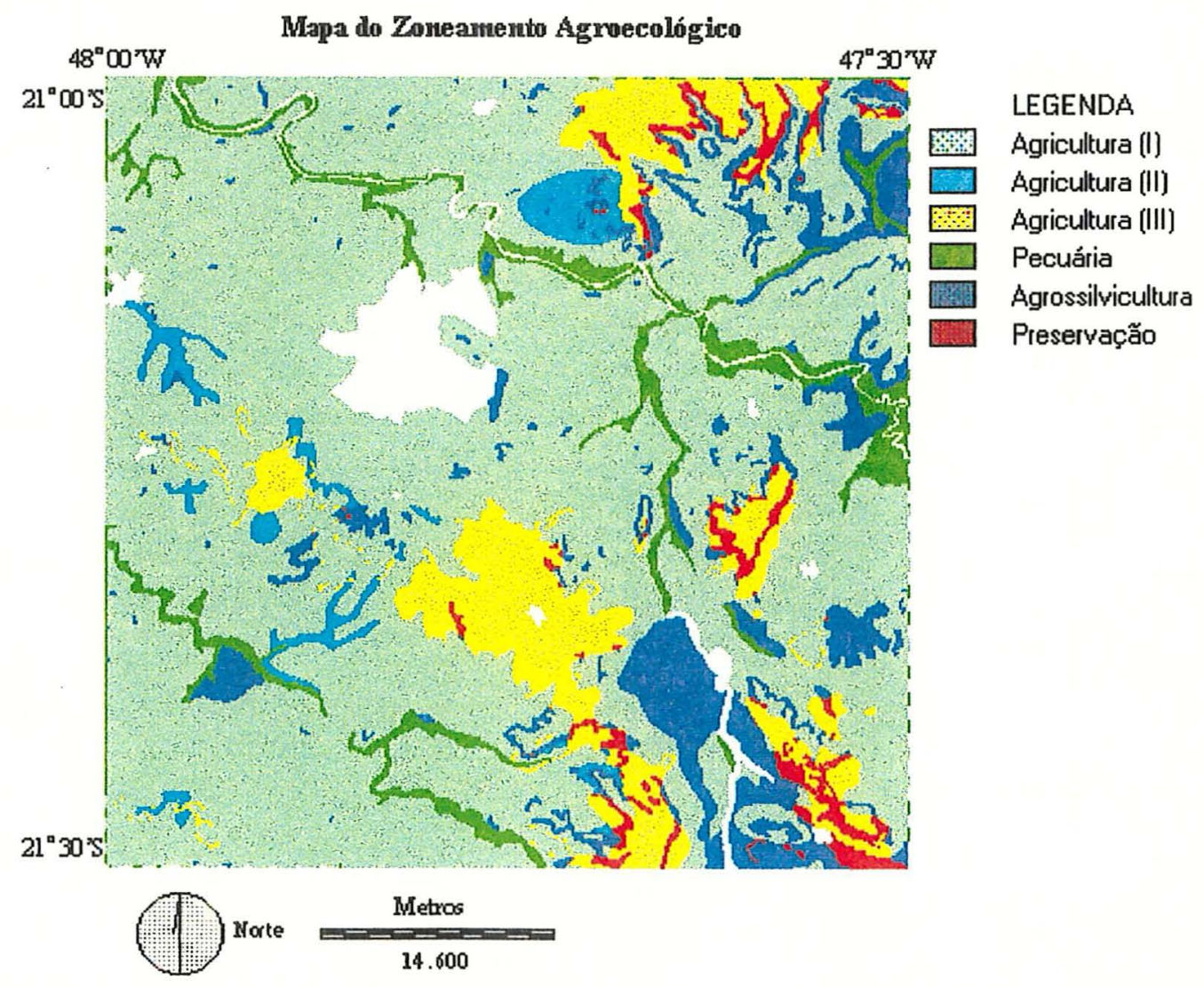

Figura 17 - Mapa de zoneamento agroecológico da quadrícula de Ribeirão Preto, SP 
A Tabela 6 quantifica a ocorrência de cada zona agroecológica, bem como as áreas não avaliadas quanto ao uso.

Tabela 6 - Zonas agroecológicas e suas respectivas áreas e percentagens, na quadrícula de Ribeirão Preto, SP.

\begin{tabular}{l|c|c}
\hline \multicolumn{1}{c|}{ Zonas agroecológicas } & Áreas ( h a) & Porcentagem (\%) \\
\hline Áreas não avaliadas & 20668,1 & 7,2 \\
\hline Agricultura (I) & 190118,4 & 66,3 \\
\hline Agricuitura (II) & 6889,3 & 2,4 \\
\hline Agricultura (III) & 25505,0 & 8,9 \\
\hline Pecuária & 14065,8 & 4,9 \\
\hline Agrossilvicultura & 24069,7 & $\mathbf{8 , 4}$ \\
\hline Preservação & 5741,2 & 2,0 \\
\hline \multicolumn{1}{c|}{ Total } & $\mathbf{2 8 7 0 5 7 , 5}$ & $\mathbf{1 0 0 , 0}$ \\
\hline
\end{tabular}

$\mathrm{Na}$ quadricula, predominam as áreas indicadas para agricultura (I), representando cerca de 191.118 hectares, correspondentes a $66,3 \%$ da área. Essas terras ocorrem em relevo suave ondulado, portanto sem limitaçōes ao emprego intensivo de máquinas agrícolas, e constituidos basicamente pelos Latossolos. Na parte oeste da quadrícula, verifica-se que o uso atual da terra, evidenciado pela Carta de Utilização da Terra, folha de Ribeirão Preto ( Brasil, 1985), e pela análise da imagem do LANDSAT - TM de 1996, é relativamente adequado, com exceção das áreas com Terra Roxa Estruturada que estão sendo utilizadas abaixo de suas potencialidades.

Verificou-se também, que as áreas indicadas para utilização com agricultura (II), cobrindo uma área de 6.889 hectares, correspondentes a 2,4\% da área da quadrícula, são representadas por terras com ótimas caracteristicas fisico-quimicas. Dominantemente pertencem a essa zona as Terras Roxas Estruturadas. Comparando essas áreas com a carta de uso atual, concluiu-se que elas estão sendo utilizadas abaixo de suas potencialidades, 
quando suas indicações deveriam ser para culturas extensivas, localizadas nas proximidades de Sertãozinho. Observou-se, por exemplo, áreas com pecuária nessas manchas de solos.

Avaliando essas informações quanto ao uso atual, constatou-se que as áreas indicadas para agrossilvicultura e preservação, que representam $10 \%$ da quadrícula, estão sendo utilizadas além de suas capacidades de suporte, tais como o uso com pecuária de grande porte, localizadas nas cercanias de São Simão e a leste do município de Jardinópolis. Essas áreas merecem maior atenção por parte dos produtores agrícolas, por serem mais indicadas ao reflorestamento ou com sistemas agroflorestais. Em visita ao campo constatou-se que os topos de morros estavam sendo utilizados com pastagens.

O zoneamento apresentou as terras indicadas para pecuária, em função dos solos, nas proximidades de áreas ribeirinhas. Entretanto, ressalta-se que o produtor deve seguir as normas técnicas do Código Florestal, que considera como área de preservação permanente as vegetações de várzeas e de banhados situadas ao longo dos rios ou de qualquer curso d'água, desde o seu nivel mais alto em faixa marginal, cuja largura depende dos mesmos. 


\section{CONCLUSÕES}

Face aos resultados obtidos no presente trabalho para a quadrícula de Ribeirão Preto, SP, conclui-se que:

a) Existe uma relativa uniformidade climática na área de estudo, evidenciada pelos valores térmico-hídricos médios;

b) a deficiência hídrica é o fator climático de maior peso na avaliação do zoneamento agroecológico, ocorrendo os maiores déficts no periodo compreendido entre junho a setembro;

c) os fatores determinantes para a indicação de zonas agroecológicas na seleção de áreas zoneadas para preservação e agrossilvicultura, na quadrícula, são os relativos ao solo e ao relevo;

d) a proposta metodológica de seleção de zonas agroecológicas em nivel macro, permiti identificar que $82,5 \%$ das terras possuem vocação para o uso com agropecuária e $10,4 \%$ devem ser preservadas ou utilizadas com técnicas conservacionistas; 
e) a quadrícula possui vocação dominante para agricultura intensiva, denominada de Agricultura (I), observando-se que, na porção noroeste da mesma que o uso atual, em sua maior parte, vem obedecendo à vocação agrícola daquela terras;

f) a utilização do recurso solo, na porção nordeste e sudeste com pecuária, sem levar em consideração as suas verdadeiras limitações, poderá trazer conseqüências aos ecossistemas frágeis, indicadas pelo zoneamento para agrossilvicultura e preservação;

g) o SIG é uma ferramenta importante para realizar a integração dos mapas temáticos de forma hierarquizada. 


\section{REFERÊNCIAS BIBLIOGRÁFICAS}

ANUÁRIO DA AGRICULTURA BRASILEIRA/ AGRIANUAL - 1997. São Paulo, p.22 - 24, 1996.

ALFONSI, R. R., PEDRO JUNIOR, M. J., PAES DE CAMARGO, M. B., ORTOLANI, A. A., BRUNINI, O., CHIAVEGATTO, O. M. D. P. Zoneamento agroclimático e probabilidade de atendimento hídrico para as culturas de soja, milho, arroz de sequeiro e feijão no estado de São Paulo. Campinas: Boletim Científico do Instituto Agronômico de Campinas, n. 37, p. 1 - 8, 1995.

ALFONSI, R. R., VICTORIA FILHO, R. Probabilidade de atendimento hídrico para a cultura do milho, no estado de São Paulo. In: CONGRESSO BRASILEIRO DE AGrometeorologiA, 10, Piracicaba, 1997. Anais. Piracicaba: SBA. 1997. p122-124

ALMEIDA, M. S. DE; FELGUEIRAS, C. A.; SHIMABUKURO, Y. E. In: SIMPÓSIO BRASILEIRO DE GEOPROCESSAMENTO, 1. Resumos. São Paulo: EPUSP, 1990 , p. $262-265$.

ALVES, D. S. Sistemas de Informações Geográfica. In: SIMPOSIO BRASILEIRO DE GEOPROCESSAMENTO, 7, São Paulo, 1990. Resumos. São Paulo:.EPUSP, 1990. p. 66-78.

ANUÁRIO ESTATÍSTICO DO ESTADO DE SÃO PAULO - 1993, p. 833, 1994. 
ASSIS, F. N. de.; ARRUDA, H.V.; PEREIRA, A. R. Aplicações de estatística à climatologia. Pelotas: ed. Universitária/UFPel, 1996. 161p. ASSAD, E. D., SANO, E. E., MASUTOMO, R. Uso de modelos numéricos de terreno na espacialização de dados pluviométricos. In: ASSAD, E. D., SANO, E. E. ed. Sistema de Informações Geográficas: aplicações na agricultura. $1^{\circ}$. ed. Brasília. EMBRAPA/SPI, 1993. p. 203227.

ASSAD, E. D., SANO, E. E. Aplicações Futuras. In: ASSAD, E. D., SANO, E. E. ed. Sistema de Informações Geográficas: aplicações na agricultura. $1^{\circ}$. ed. Brasília. EMBRAPA/SPI, 1993. p. 251-257.

AYOADE, J. O. Introdução a climatologia para os trópicos. Trad. M. J. Z. dos Santos. Rio de Janeiro: Bertrand Brasil, 1996. 332p.

BARBIERI, V., TUON, R. L., ANGELOCCI, L. R. Programa para microcomputador do balanço hídrico ( Thornthwaite e Mather, 1955) para dados mensais e decendiais, normais e seqüências. In: CONGRESSO BRASILEIRO DE AGROMETEOROLOGIA, 7, Viçosa, 1991. Anais. Viçosa: SBA, 1991. p. 297-299.

BARROS, E. U. A. de. Utilização do geoprocessamento em estudos de suscetibilidade à erosão na área de influência da UHE Barra do Peixe. Brasília DF, 1996. 113p. Dissertação (Mestrado) - Faculdade de Tecnologia - Universidade de Brasilia.

BERTONI, J., LOMBARDi NETO, F. Conservação do solo. São Paulo, Ícone, 1990. $355 \mathrm{p}$.

BRADY, N. C. Natureza e propriedade do solo. Trad. A. B. N. Figueiredo. Rio de Janeiro: Freitas Bastos, 1989. 898p.

BRASIL. MINISTÉRIO DA AGRICULTURA E .SECRETARIA NACIONAL DE PLANEJAMENTO AGRICOLA. Aptidão agrícola das terras de São Paulo. Brasilia: BINAGRI, 1979. 114p. 
BURROUGH, P. A. Principles of Geographical Information Systems for Lland Resources Assessment., Oxford: Clarendon Press, 1988. 194p.

CABEDA, M. S. V. Computação dos valores de EI das chuvas naturais. Porto Alegre. UFRGS - Faculdade de Agronomia. 1977. 10p.

CAMARGO, A. Aptidão Climática para as culturas da soja, girassol e amendoim, no Estado de São Paulo. In: Zoneamento da aptidão ecológica para a cultura de soja, girassol e amendoim do Estado de São Paulo. São Paulo: INSTIÓLEOS, 1971. $35 \mathrm{p}$.

CAMARGO, A., PINTO, H.S., PEDRO JR. M. J., BRUNINI, O., ALFONSI, A. A., ORTOLANI, A. A. Aptidão climática de culturas agrícolas. Campinas: Instituto Agronômico, 1974. v.1,. 154p.

CAMARGO, M. B. P. de., PEDRO JUNIOR, M. J., ALFONSI, R. R., ORTOLANI, A. A., BRUNINI, O. Probabilidade de ocorrência de temperaturas mínimas absolutas mensais e anual no estado de São Paulo. Bragantia, Campinas, 1993 p. 161-168

CASTRO, F. S. DE. Conservacion de suelos. Ed. IICA. $3^{\circ}$. ed. San José - Costa Rica. 1980. $315 \mathrm{p}$.

CHAIM, R.A.R.; SANTOS, M. J..Z. Evolução têmporo-espacial da cultura do feijão das águas na região de Ribeirão Preto (SP). Boletim Climatológico, n.3, p. 49-55, julho, 1997.

CHOW, V. T. Handbook of appled hydroloy. McGraw-Hill. New York. 1964. p. 249.

CINTRA, J. P. Sistema U.T.M: noções de geodésia e cartografia. Escola Politécnica da USP, Dep. de Transporte, 64p, 1988 (Apostila).

COSTA. A. C. L. Contribuição ao zoneamento agroclimático para a cultura do sorgo (Sorghum bicolor L. Moench) no estado de Minas Gerais. Viçosa: UFV, p.61, 1988. 
COSTA, T. C. C. da., SOUZA, M. G. de., BRITES, R. S. Delimitação e caracterização de áreas de preservação permanente, por meio de uma Sistema de Informações Geográficas (SIG). In: SIMPÓSIO BRASILEIRO DE SENSORIAMENTO REMOTO, 8. Resumos. Salvador, BA. 1996, 7 p.

COUTO, H. T. Z.; VETTORAZZI, C. A. A Tecnologia do Geoprocessamento para a Engenharia Florestal. In: SIMPÓSIO BRASILEIRO DE GEOPROCESSAMENTO, 1. Resumos. São Paulo: EPUSP, 1990, p. 204 - 208.

CUNHA, G. R., HAAS, J. C., ASSAD, E. D., Zoneamento de riscos climáticos para a cultura do trigo no estado do Rio Grande do Sul. In: CONGRESSO BRASILEIRO DE AGROMETEOROLOGIA, 10. Anais. Piracicaba: SBA, 1997, p. $372-373$.

DEPARTAMENTO DE ÁGUAS E ENERGIA ELÉTRICA. Diagnóstico básico do plano de irrigação do estado de São Paulo: atlas de desenvolvimento. São Paulo, 1973. 38p.

EASTMAN, J. R. Idrisi version 4.0 - Users guide. Massachusetts, Clark University, 1992. $178 \mathrm{p}$.

EASTMAN, J. R. Idrisi for windows. Exercícios tutoriais. Editor da versão em português Heinrich Hasenack. Porto Alegre, UFRGS Centro de Recursos Idrisi, 1996. $109 \mathrm{p}$.

FEEMA. FUNDAÇÃO ESTADUAL DE ENGENHARIA DO MEIO AMBIENTE. Lei $N^{\circ} .6 .938$ de 31 de agosto de 1980. Inciso II, artigo $9^{\circ} .1980$.

FERRAZ, F. F. de B. Aplicação de sistema de informações geográficas em estudo de área urbana de Piracicaba sujeita a inundação. Piracicaba, 1996. 90p. Dissertação (Mestrado) - Escola Superior "Luiz de Queiroz", Universidade de São Paulo.

FERRAZ, S. F. DE B.; VETTORAZZI, C. A. Emprego do índice de Monte Alegre em um Sistema de Informações Geográficas na produção de mapas diários de risco de 
incêndios em áreas florestais. In: CONGRESSO BRASILEIRO DE AGROMETEOROLOGIA, 10, Piracicaba, 1997. Anais. Piracicaba: SBA, 1997. p401-403

FERREIRA, M. C. Modelagem cartográfica aplicada a mapeamentos de suscetibilidade a danos ambientais: um ensaio no SIG IDRISI. São Paulo: Geociências, v. 15, n. 2,.p.485-502, 1996.

ELTZ, F. L. F., REICHERT, J. M., CASSOL, E. A. Período de retorno de chuvas em Santa Maria, RS. Revista Brasileira de Ciência do Solo, Campinas, v. 16, p. 265 269, 1992.

FORMAGGIO, A. R.; ALVES, D. S.; EPIPHANIO, J. C. N. Sistema de informações geográficas na obtenção de mapas de aptidão agrícola e de taxa de adequação de uso das terras. Revista Brasileira de Ciência do Solo, Campinas, v. 16, p. 249 -256, 1992.

INMET-BRASIL. MINISTÉRIO DA AGRICULTURA E REFORMA AGRÁRIA. SECRETARIA NACIONAL DE IRRIGAÇÃO. INSTITUTO NACIONAL DE METEOROLOGIA. Normais Climatológicas (1960-1990). Brasília, 1992. 84p.

INSTITUTO FLORESTAL/IF. Inventário Florestal do Estado de São Paulo -. São Paulo. 1993 p.28.

KÖPPEN, W (1918). Climatologia: com un estudio de los climas de la tierra (Tradução: Pedro R. Hendrichs Pérez). Buenos Aires, 1931.

KOFFLER, N. F. Diagnóstico do uso das terras da bacia do Rio Bauru através de técnicas automatizadas. Bauru - SP, 1996.41p.

LEOPOLDO, P. R.; SANSIGOLO, C. A. ; MARTINS, D. Análise estatística das intensidades e precipitações máximas de Botucatu - SP. Irrigação e Tecnologia Moderna. n. 16. 1984. p. 11-14. 
LEPSCH, I. F.; SARAIVA, I. R.; DONZELI, P. L.; MARINHO, M. de A.; SAKAI, E.; GUILLAUMON, J. R.; PFEIFER, R. M.; MATTOS, L. F. de A.; ANDRADE, W. J. de; SILVA, C. E. F. da. Macrozoneamento das terras da região do Rio Ribeira de Iguape, SP. Campinas: Boletim do Instituto Agronômico de Campinas, n.19, $181 \mathrm{p}, 1990$.

MAGALHÃES, J. C. de. Região Sudeste. In: BRASIL. INSTITUTO BRASILEIRO DE GEOGRAFIA. "Novo" Paisagens do Brasil. Rio de Janeiro: IBGE, 1974. $2^{\circ}$. parte. p. $230-243$.

MIRANDA, E. E. de., DORADO, A. J., GUIMARÃES, M., MANGABEIRA, J. A. de C., MIRANDA, J. R. Sistema de Informações Geográficas na avaliação da sustentabilidade agrícola. In: SIMPÓSIO BRASILEIRO DE SENSORIAMENTO REMOTO, 8. Resumos. Salvador, BA: 1996, p. 1 - 7.

MOREIRA, N .D .F. Curso de Direito Administrativo. 3ed. Rio de Janeiro: Frense $1976,190 \mathrm{p}$.

MULLER ,J.C. Geographic Information Systems: a unifying force for geography. the operational geography. v.8, 1985, p. 41-43.

OLIVEIRA. J. B. de. Características morfológicas, analíticas, limitações e aptidão agrícola dos solos da quadrícula de Campinas. Campinas: Boletim do Instituto Agronômico de Campinas. n. 109, 70p, 1980.

OLIVEIRA JÚNIOR, D.R. Espacialização do risco de enxurradas e de estresse hídrico no Distrito Federal, através do Sistema de Informações Geográficas. Brasília, 1994. 55p. Dissertação (Mestrado) - . Universidade Federal de Brasília.

OLIVEIRA. J. B. de; PRADO, H. do. Levantamento pedológico semidetalhado do Estado de São Paulo: quadrícula de Ribeirão Preto. II. Memorial Descritivo. Campinas: Boletim do Instituto Agronômico de Campinas. n. 7, 133p, 1987. 
OLIVEIRA.J.B.; BERG, M.V. Aptidão agricola. das terras do estado de São Paulo. Quadricula de Araras. Campinas: Boletim do Instituto Agronômico de Campinas. 60 p., 1985.

PALMIERI, F. , LARACH, J. O. I. Pedologia e Geomorfologia. In: GUERRA, A. J. T., CUNHA, S. B. Geomorfologia e Meio Ambiente. Rio de Janeiro: Bertrand Brasil, 1996. Cap. 2 p. 59-122.

PEDRO JUNIOR, M. J.; MELLO, M. H. de A.; ORTOLANI, A. A.; SENTELHAS, P. C. Estimativa das temperaturas médias mensais das máximas e das mínimas para o Estado de São Paulo. Campinas: Boletim Técnico do Instituto Agronômico de Campinas, n. 142, 11p., 1991

PEZZOPANE, J. E.; LIMA, P. C. da S.; CUNHA, G. de M.; ESPOSTI, M. D. D.; SANTOS, A. R. Zoneamento climático de perda da produtividade potencial do feijoeiro, em função do déficit hídrico, na região do Sul do Espírito Santo. In: CONGRESSO BRASILEIRO DE AGROMETEOROLOGIA, 10. Resumos. Piracicaba: SBA, 1997. p 342-343.

PFAFSTETTER, O. Chuvas Intensas no Brasil. Rio de Janeiro: Departamento Nacional de Obras de Saneamento - DNOS. 1957. 42p.

PICCINNI, M. R. D.; ANGELOCCI, L. R. Probabilidade de precipitação de intensidade máxima para Piracicàba, SP. In: CONGRESSO BRASILEIRO DE AGROMETEOROLOGIA, 10. Resumos. Piracicaba: SBA, 1997. p. 128 - 130.

RAMALHO FILHO, A.; BEEK,K.J. Sistema de avaliação da aptidão agrícola das terras. Rio de Janeiro. EMBRAPA-CNPS, 1995. $3^{\circ}$. ed. 65p.

REIS, J. C. Proposição metodológica para estudo e mensuração do processo de assoreamento de reservatórios, utilizando Sistema de Informações Geográficas. Viçosa, 1995. 119p. Dissertação (Mestrado) - Universidade Federal de Viçosa. 
SÁNCHEZ, R. O. Zoneamento agroecológico: objetivos, conceitos centrais e aspectos metodológicas. Cuiabá: Fundação de Pesquisa Cândido Rondon, 1989. 31 p.

SANS, L. M. A.; ASSAD, E. D.; AVELLAR, G. de; FARIA, C. M. de; SOUZA, L. F de. Riscos climáticos para a cultura do milho nos estados de Minas Gerais, Goiás, Tocantins, Mato Grosso e Mato Grosso do Sul. In: CONGRESSO BRASILEIRO DE AGROMETEOROLOGIA, 10. Anais. Piracicaba: SBA, 1997. p 357-359.

SANTOS, M. J. Z. dos. Distribuição têmporo-espacial da cultura da soja na região nordeste do Estado de São Paulo (1974-89). Revista Brasileira de Agrometeorologia, v.4, n.2, p. 123-132, 1996.

SISMANOGLU, R. A.; RESCHKE, G, A. de; PRATES, J. E. Zoneamento agroclimático do Brasil aplicando sistemas de informações geográficas. In: CONGRESSO BRASILEIRO DE AGROMETEOROLOGIA, 10. Anais. Piracicaba: SBA, 1997. p 304-305.

SÃO PAULO (Estado). Secretária de Economia e Planejamento. Coordenadoria de Ação Regional. Carta de Utilização da Terra do Estado de São Paulo. São Paulo: IGCE , 1985. Folha SF-23-V- C, Escala 1:250.000.

SÃO PAULO (Estado). Secretária de Economia e Planejamento. Coordenadoria de Ação Regional. Carta Topográfica de Ribeirão Preto. São Paulo: TerraFoto/IBGE, 1978 Folha Região Administrativa de Ribeirão Preto, Escala 1:250.000.

THOMÉ, V. M. R.; ZAMPIERI, S. L.; BRAGA H. J.; MASSIGNAM, A. M.; ALTHOFF, D. A.; PANDOLFO, C.; MIRANDA, G. X. de . Zoneamento agrícola para a cultura do milho em Santa Catarina. In: CONGRESSO BRASILEIRO DE AGROMETEOROLOGIA, 10. Anais. Piracicaba: SBA, 1997. p 333 - 335.

THOMÉ, V. M. R.; ZAMPIERI, S. L.; BRAGA, H. J. Zoneamento agrícola para a cultura do trigo em Santa Catarina. Florianópolis: EPAGRI, 1996, 24p. 
THOMÉ, V. M. R.; ZAMPIERI, S. L.; BRAGA, H. J.; ALTHOFF, D..A.; PANDOLFO, C. MIRANDA Jr. G. X. de. Zoneamento agrícola para a cultura da soja em Santa Catarina. In: CONGRESSO BRASILEIRO DE AGROMETEOROLOGIA, 10. Anais. Piracicaba: SBA, 1997, p. $330-332$.

THORNTHWAITE, C. W.. An approach toward a rational classification of climate. Geogr. Rev., n. 38, p. 55-94, 1948.

THORNTHWAITE, C. W. MATHER. J. R. The water balance. Drexel: Institute of Technology, 1955, 104p.

VENTURIM, R. P., BAHIA, V. G. Considerações sobre os principais solos de Minas Gerais e sua susceptibilidade à erosão . Informe Agropecuário. v.19, n.191, p. 7-9, 1998.

VETTORAZZI, C. A. Sensoriamento remoto orbital. Escola Superior de Agricultura “Luiz de Queiroz", Dep. de Engenharia Rural, 134p, 1992 (Apostila ).

VIEIRA, S. R.; LOMBARDI NETO, F. ; BURROWS, I. T. Mapeamento da chuva diária máxima provável para o Estado de São Paulo. Revista Brasileira de Ciência do Solo, v. 15, p. 93 - 98, 1991.

YOUNG, J. A. T. Geographic information systems. AUK geographic information system for environment monitoring, resource planning \& management capable of integrating using satellite remotely sensed data. Nothingham. University of Nothingham. 1986. p. 5 - 26. 
ANEXO A - Valores de Temperaturas Extremas

\section{(1) Temperaturas Máximas}

\begin{tabular}{|c|c|c|c|c|c|c|c|c|c|c|c|}
\hline Meses & Jartinópotis & C. Regatus & R. Preto(LAC) & R. Preto(DAEE) & FaL Sta Ametis & F. Flores & Cravinhos & C. $\mathrm{da}_{2} \mathrm{Cnz}$ & F. Stu. Cun & S. Simato & P. Tremanutui \\
\hline Jan & 30.3 & 31 & 29.7 & 30.3 & 30.2 & 29,2 & 29.4 & 30.3 & 29.2 & 29.8 & 30.3 \\
\hline Fev & 30.4 & 31.1 & 30.3 & 30.4 & 30.3 & 29.3 & 29.4 & 30.3 & 29.2 & 30.6 & 30.1 \\
\hline Mar & $\$ 0.3$ & 30.9 & 30.1 & 30.2 & 30.1 & 29.1 & 29.2 & 30.1 & 29.1 & 30.3 & 29,9 \\
\hline $\mathrm{Abr}$ & 29.2 & 29.8 & 28.9 & 29 & 28.9 & 27.9 & 28 & 28.9 & 27.8 & 29 & 28.6 \\
\hline Maio & 27.4 & 28 & 27.1 & 27.3 & 27.1 & 26,2 & 26.3 & 27.1 & 26.1 & 27 & 26,8 \\
\hline Jur & 26.4 & 27 & 26.2 & 26.3 & 26.1 & 25.2 & 25.3 & 26 & 25.1 & 25.9 & 25,8 \\
\hline Jul & 26.8 & 27,3 & 26.6 & 26.6 & 26.4 & 25.5 & 25.6 & 26.3 & 25.5 & 26.3 & 26,1 \\
\hline Ago & 29.3 & 29.9 & 28.9 & 29.1 & 28.9 & 27.9 & 28 & 28,8 & 27.8 & 28.4 & 28,5 \\
\hline Set & 30.5 & 31 & 29.6 & 30.2 & $\$ 0.1$ & 29,1 & 29.2 & 29,9 & 29 & 29 & 29.6 \\
\hline Out & 30.6 & 31.1 & 30.3 & 30.3 & 30.2 & 29.2 & 29.3 & 30.1 & 29.1 & 30.5 & 29.8 \\
\hline Nov & 30.4 & 31,1 & 29.9 & 30.3 & 30.1 & 29.1 & 29.2 & 30.1 & 29.1 & 30.3 & 29.9 \\
\hline Dez & 30 & 30.7 & 29.3 & 29.9 & 29.8 & 28.8 & 29 & 29,8 & 28.8 & 29.4 & 29.6 \\
\hline Média & 29,3 & 29,9 & 28,9 & 29,2 & 29,0 & 28,0 & 28.2 & 29,0 & 28.0 & 28,9 & 28,8 \\
\hline
\end{tabular}

\section{(2) Temperaturas Mínimas}

\begin{tabular}{|c|c|c|c|c|c|c|c|c|c|c|c|}
\hline Meses & Jardinopolis & C. Regatas & R. PretotiACI & R. Preto 1DAE & Faz. Sta. Ame & F. Flores & Cravinhos & C. da Cruz & F. Sta. Clara & S. Simáo & P. Tamandui \\
\hline Jan & 19 & 19.5 & 18.7 & 19 & 18.9 & 18.2 & 18.3 & 19 & 18.1 & 19.7 & 18.8 \\
\hline Fer & 19.2 & 19.7 & 18.6 & 19.2 & 19.1 & 18.4 & 18.5 & 19.1 & 18.3 & 19.7 & 19 \\
\hline Mar & 18.6 & 19.1 & 18.1 & 18.5 & 18.4 & 17.7 & 17.8 & 18.5 & 17.6 & 18.7 & 18.3 \\
\hline Abr & 16.1 & 16.5 & 16.3 & 16 & 15.9 & 15.1 & 15.3 & 15.9 & 15.1 & 17.3 & 15.7 \\
\hline Maio & 13.4 & 13.9 & 13.9 & 13.4 & 13.3 & 12.5 & 12.6 & 13.3 & 12.5 & 14.3 & 13.1 \\
\hline Jun & 12.2 & 12.7 & 12.4 & 12.1 & 12 & 11.2 & 11.3 & 12 & 11.1 & 11.6 & 11.8 \\
\hline Jul & 11.6 & 12.1 & 12.0 & 11.5 & 11.4 & 10.7 & 10.8 & 11.4 & 10.6 & 11.4 & 11.2 \\
\hline Ago & 13.2 & 13.7 & 13.6 & 13.1 & 13 & 12.2 & 12.3 & 12.9 & 12.1 & 13.2 & 12.7 \\
\hline Set & 15.3 & 15.8 & 15.5 & 15.2 & 15.1 & 14.2 & 14.3 & 15 & 14.2 & 15.6 & 14.8 \\
\hline Out & 17 & 17.5 & 17.0 & 16.9 & 16.7 & 16 & 15.1 & 16.7 & 15.9 & 17.4 & 16.5 \\
\hline Nov & 17.6 & 18.1 & 18.0 & 17.5 & 17.4 & 16.6 & 16.7 & 17.4 & 16.6 & 18.6 & 17.2 \\
\hline Dez & 18.6 & 19.1 & 18.6 & 18.5 & 18.4 & 17.7 & 17.8 & 18.5 & 17.6 & 19.4 & 18.3 \\
\hline Média & 16.0 & 16.5 & 16.0 & 15.9 & 15.8 & 15.0 & 15.2 & 15.8 & 15.0 & 16.4 & 15.6 \\
\hline
\end{tabular}


ANEXO B - Freqüências de chuvas por qüinqüídios, no verão e outono, em Ribeirão Preto, SP.

\begin{tabular}{|c|c|c|c|c|c|c|c|c|c|c|c|c|c|c|c|c|c|c|c|c|c|c|c|c|c|c|c|c|c|c|c|c|}
\hline \multirow[b]{3}{*}{ Chuvamm) } & \multicolumn{16}{|c|}{ Verao } & \multicolumn{16}{|c|}{ Outono } \\
\hline & \multicolumn{6}{|c|}{ Desmiro } & \multicolumn{4}{|c|}{ Janciro } & \multicolumn{6}{|c|}{ Feveriro } & \multicolumn{5}{|c|}{ Marpo } & \multicolumn{6}{|c|}{ Abril } & \multicolumn{5}{|c|}{ M:io } \\
\hline & $1^{\circ}$ & $2^{\circ}$ & $3^{\circ}$ & $4^{\circ}$ & $5^{\circ}$ & $6^{\circ}$ & $1^{\circ}$ & 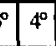 & $5^{\circ}$ & $6^{\circ}$ & $1^{\circ}$ & $2^{0}$ & $3^{\circ}$ & $4^{0}$ & 5 & $\theta+$ & $1^{\circ}$ & \begin{tabular}{|l|l|}
$2^{0}$ & $3^{\circ}$ \\
\end{tabular} & $4^{\circ}$ & $5^{\circ}$ & $6^{\circ}$ & $1^{\circ}$ & $2^{0}$ & $3^{\circ}$ & $4^{\circ}$ & 50 & \begin{tabular}{l|l}
$6^{\circ}$ & $1^{\circ}$
\end{tabular} & 2 & 30 & $4^{\circ}$ & $5^{\circ}$ & $6^{\circ}$ \\
\hline 5 & 3 & 3 & 4 & 3 & 5 & 3 & 1 & 6 & 7 & 4 & 7 & 3 & 6 & 7 & 6 & 10 & 9 & \begin{tabular}{|l|l|}
7 & 9 \\
\end{tabular} & 10 & 12 & 9 & 15 & 11 & 16 & 17 & 14 & \begin{tabular}{|l|l|}
23 & 17 \\
\end{tabular} & \begin{tabular}{l|l|}
77 & 19 \\
\end{tabular} & 20 & 18 & 20 & 21 \\
\hline 10 & 4 & 2 & 1 & 4 & 1 & 0 & 2 & 14 & 2 & 1) & 1 & 11 & 5 & 1 & 4 & 6 & 3 & \begin{tabular}{|l|l|}
3 & 1 \\
\end{tabular} & 0 & 4 & 3 & 1 & 3 & 2 & 2 & 2 & 2 & 3 & 1 & 3 & 1 & 1 \\
\hline 15 & 4 & 4 & 3 & 2 & 2 & 0 & 3 & 0 & 2 & 2 & 2 & 6 & 0 & 4 & 1 & 4 & 1 & 0 & 2 & 0 & 2 & 0 & 7 & 0 & 1 & 4 & 0 & \begin{tabular}{ll|}
1 & 1
\end{tabular} & 3 & 1 & 2 & 1 \\
\hline 20 & 2 & 4 & 1 & 2 & 0 & 3 & 1 & \begin{tabular}{|l|l|}
2 & 1 \\
\end{tabular} & 5 & 3 & 1 & 2 & 0 & 3 & 3 & 5 & 1 & \begin{tabular}{|l|l|}
4 & 3 \\
\end{tabular} & 4 & 0 & 4 & 1 & 2 & 2 & 1 & 1 & 2 & \begin{tabular}{|l|l|}
0 & 2 \\
\end{tabular} & 3 & 1 & 0 & 1 \\
\hline 25 & $i$ & 1 & 0 & 1 & 0 & 2 & 2 & 12 & 3 & 1 & 2 & 2 & 0 & 1 & 4 & 0 & 2 & 1 & 4 & 2 & 4 & 3 & 2 & 0 & 0 & 2 & 2 & $\begin{array}{lll}0 & 1\end{array}$ & 0 & 1 & 0 & 0 \\
\hline 30 & 1 & 1 & 2 & 4 & 2 & 3 & 3 & \begin{tabular}{|l|l|}
0 & 3
\end{tabular} & 0 & 0 & 0 & 0 & 1 & 0 & 2 & 1 & 0 & 1 & 0 & 1 & 2 & 1 & 1 & 2 & 2 & 2 & 0 & \begin{tabular}{|l|l|}
3 & 0
\end{tabular} & 0 & 0 & 2 & 0 \\
\hline 35 & 4 & 2 & 3 & 1 & 2 & 0 & 3 & \begin{tabular}{|l|l|}
4 & 0
\end{tabular} & 0 & 4 & 1 & 11 & 3 & 2 & 1 & 1 & 2 & \begin{tabular}{|l|l|}
2 & 2 \\
\end{tabular} & 2 & 3 & 1 & 0 & 0 & 1 & 3 & 1 & 0 & $\begin{array}{ll}1 & 1\end{array}$ & 1 & 3 & 0 & 2 \\
\hline 40 & 2 & 0 & 1 & 1 & 1 & 2 & 4 & \begin{tabular}{|l|l}
4 & 1
\end{tabular} & 1 & 1 & 2 & 2 & 1 & 2 & 1 & 0 & 4 & \begin{tabular}{l|l|}
0 & 1 \\
\end{tabular} & 1 & 2 & 0 & 2 & 0 & 1 & 2 & 1 & 0 & \begin{tabular}{l|l}
0 & 1 \\
\end{tabular} & 1 & 0 & 2 & 1 \\
\hline 45 & 0 & 3 & 1 & 1 & 2 & 5 & 4 & 13 & 1 & 11 & 1 & 0 & 2 & 4 & 1 & 1 & 1 & \begin{tabular}{l|l|}
1 & 3 \\
\end{tabular} & 2 & 2 & 1 & 3 & 0 & 1 & 0 & 0 & 0 & 20 & & 0 & 1 & 1 \\
\hline 50 & 0 & 3 & 2 & 0 & 1 & 1 & 0 & 2 & 1 & 2 & 0 & 1 & 2 & 0 & 0 & 0 & 2 & \begin{tabular}{|l|l|}
1 & 1 \\
\end{tabular} & 0 & 0 & 0 & 0 & 1 & 2 & 1 & 0 & 0 & 2 & & 3 & 0 & 0 \\
\hline 55 & 0 & 2 & 1 & 2 & 3 & 0 & 0 & 0 & 1 & 1 & 2 & 2 & 0 & 0 & 0 & 1 & 4 & \begin{tabular}{l|l|}
1 & 0
\end{tabular} & 1 & 1 & 1 & 1 & 0 & 0 & 0 & 0 & 1 & & & & 1 & 0 \\
\hline 60 & 2 & 1 & 2 & 2 & 1 & 1 & 0 & 0 & 0 & 3 & 0 & 1 & 0 & 0 & 2 & 0 & 0 & \begin{tabular}{l|l|}
1 & 1
\end{tabular} & 1 & 0 & 0 & 1 & 1 & 2 & 0 & 2 & 0 & & & & 0 & 0 \\
\hline 65 & 0 & 0 & 2 & 2 & 1 & 1 & 0 & 0 & 1 & 1 & 0 & 1 & 2 & 1 & 0 & 0 & 0 & \begin{tabular}{|l|l|}
3 & 1 \\
\end{tabular} & 0 & 0 & 0 & 0 & 0 & 0 & 0 & 0 & 1 & 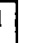 & & & 0 & 0 \\
\hline 70 & 0 & 0 & 0 & 0 & 1 & 2 & 0 & 0 & 1 & 1 & 1 & 2 & 0 & 0 & 0 & 0 & 0 & \begin{tabular}{|l|l|}
3 & 1 \\
\end{tabular} & 0 & 0 & 1 & 0 & 0 & 0 & 0 & 0 & & & & & 0 & 1 \\
\hline 75 & 1 & 0 & 3 & 1 & 0 & 0 & 11 & 0 & 0 & 1 & 2 & 0 & 0 & 0 & 0 & 0 & 0 & \begin{tabular}{l|l|}
0 & 0 \\
\end{tabular} & 1 & 0 & 0 & 1 & 0 & 0 & 0 & 0 & & & & & 1 & 0 \\
\hline 80 & 0 & 0 & 1 & 0 & 3 & 1 & 0 & 0 & 0 & 1 & 1 & 0 & 2 & 0 & 1 & 0 & 0 & \begin{tabular}{l|l|}
0 & 0 \\
\end{tabular} & 0 & 0 & 0 & 0 & 0 & 0 & 0 & 0 & & & & & & 0 \\
\hline 85 & 0 & 1 & 0 & 0 & 1 & 1 & 2 & 2 & 1 & 0 & 0 & 1 & 0 & 2 & 1 & 0 & 0 & \begin{tabular}{l|l|}
0 & 0 \\
\end{tabular} & 0 & 0 & 0 & 0 & 1 & 0 & 0 & 0 & & & & & & 0 \\
\hline 90 & 1 & 0 & 1 & 0 & 1 & 2 & 2 & 1 & 0 & 1 & 0 & 0 & 3 & 2 & 1 & 0 & 0 & \begin{tabular}{l|l|}
1 & 0 \\
\end{tabular} & 1 & 1 & 1 & 0 & 0 & 0 & 0 & 0 & & & & & & 0 \\
\hline 95 & 11 & 1 & 0 & 0 & 0 & 0 & 1 & 2 & 1 & 1 & 1 & 0 & 0 & 0 & 0 & 0 & 0 & 0 & 0 & 0 & 0 & 0 & 0 & 1 & 0 & 0 & & & & & & 0 \\
\hline 100 & 0 & 0 & 0 & 0 & 1 & 0 & 0 & 0 & 0 & 0 & 0 & 2 & 1 & 0 & 1 & 0 & 0 & 0 & 0 & 0 & 0 & 1 & 1 & & 0 & 0 & & & & & & 0 \\
\hline 105 & 0 & 0 & 0 & 1 & 0 & 1 & 0 & 0 & 0 & 0 & 0 & 0 & 11 & 0 & 0 & 0 & 0 & 0 & 0 & 0 & 0 & & & & 0 & 1 & & & & & & 0 \\
\hline 110 & 0 & 0 & 0 & 0 & 0 & 0 & 0 & \begin{tabular}{|l|l|}
0 & 0
\end{tabular} & 0 & 0 & 1 & 2 & 0 & 0 & 0 & 0 & 0 & 1 & 0 & 0 & 0 & & & & 0 & & & & & & & 0 \\
\hline 115 & 0 & 0 & 0 & 0 & 1 & 0 & 0 & 0 & 0 & 0 & 0 & 0 & 0 & 0 & 0 & 0 & 0 & & 0 & 0 & 0 & & & & 0 & & & & & & & 1 \\
\hline 120 & 1 & 0 & 1 & 0 & 0 & 1 & 0 & $\begin{array}{ll}0 & 1\end{array}$ & 1 & 1 & 0 & 0 & 0 & 0 & 0 & 0 & 0 & & 0 & 1 & 0 & & & & 1 & & & & & & & \\
\hline 125 & 0 & 1 & 0 & 0 & 1 & 1 & 0 & 0 & 0 & & 0 & 0 & 0 & 0 & 0 & 0 & 0 & & 0 & 0 & 0 & & & & & & & & & & & \\
\hline 130 & 0 & 0 & 0 & 0 & & & 1 & 1 & 1 & & 2 & 0 & 0 & 0 & 0 & 0 & 0 & & 0 & 0 & 0 & & & & & & & & & & & \\
\hline 135 & 1 & 0 & 0 & 0 & & & & 0 & 0 & & 0 & 0 & 0 & 1 & 0 & 0 & 1 & & 0 & 0 & 1 & & & & & & & & & & & \\
\hline 140 & 0 & 0 & 0 & 0 & & & & 0 & 0 & & 0 & 1 & 0 & & 0 & 1 & & & 0 & 1 & & & & & & & & & & & & \\
\hline 145 & 0 & 0 & 0 & 0 & & & & 0 & 1 & & 11 & & 0 & & 0 & & & & 0 & & & & & & & & & & & & & \\
\hline 150 & 1 & 0 & 0 & 0 & & & & 0 & & & 0 & & 0 & & 0 & & & & 0 & & & & & & & & & & & & & \\
\hline 155 & & 0 & 0 & 1 & & & & 0 & & & 0 & & 1 & & 1 & & & & 0 & & & & & & & & & & & & & \\
\hline 160 & & 0 & 0 & 0 & & & & 0 & & & 1 & & & & & & & & 1 & & & & & & & & & & & & & \\
\hline 165 & & 1 & 0 & 0 & & & & 0 & & & 0 & & & & & & & & & & & & & & & & & & & & & \\
\hline 170 & & & 0 & 0 & & & & 0 & & & 0 & & & & & & & & & & & & & & & & & & & & & \\
\hline 175 & & & 0 & 0 & & & & 0 & & & 0 & & & & & & & & & & & & & & & & & & & & & \\
\hline 180 & & & 0 & 0 & & & & 1 & & & 0 & & & & & & & & & & & & & & & & & & & & & \\
\hline 185 & & & 0 & 1 & & & & & & & 0 & & & & & & & & & & & & & & & & & & & & & \\
\hline 190 & & & 0 & 0 & & & & & & & 0 & & & & & & & & & & & & & & & & & & & & & \\
\hline 195 & & & 1 & 1 & & & & & & & 1 & & & & & & & & & & & & & & & & & & & & & \\
\hline
\end{tabular}


ANEXO C - Freqüências de chuvas por qüinqüídios, no inverno e primavera, em Ribeirăo Preto, SP.

\begin{tabular}{|c|c|c|c|c|c|c|c|c|c|c|c|c|c|c|c|c|c|c|c|c|c|c|c|c|c|c|c|c|c|c|c|c|c|}
\hline \multirow[b]{3}{*}{ Chrvamm) } & \multicolumn{16}{|c|}{ Inverno } & \multicolumn{17}{|c|}{ Primavera } \\
\hline & \multicolumn{5}{|c|}{ Junho } & \multicolumn{5}{|c|}{ Julho } & \multicolumn{6}{|c|}{ Agosto } & \multicolumn{5}{|c|}{ Setentro } & \multicolumn{6}{|c|}{ Orutro } & \multicolumn{6}{|c|}{ Noventro } \\
\hline & \begin{tabular}{l|l|}
$1^{\circ}$ & $2^{\circ}$ \\
\end{tabular} & $3^{\circ}$ & $4^{\circ}$ & $5^{\circ}$ & $6^{\circ}$ & $1^{\circ}$ & \begin{tabular}{l|l|}
$2^{2}$ & $3^{0}$ \\
\end{tabular} & $4^{\circ}$ & 50 & $6^{\circ}$ & $1^{\circ}$ & $2^{\circ}$ & $3^{\circ}$ & $4^{\circ}$ & 5 & $6^{\circ}$ & $i^{n}$ & 20 & $3^{0}$ & $4^{\circ}$ & \begin{tabular}{l|l}
$5^{\circ}$ & $6^{\circ}$ \\
\end{tabular} & $1^{\circ}$ & 20 & $3^{\circ}$ & $4^{\circ}$ & $5^{\circ}$ & $6^{\circ}$ & $1^{\circ}$ & $2^{\circ}$ & $3^{\circ}$ & $4^{\circ}$ & \begin{tabular}{l|l}
5 & 6
\end{tabular} & $\theta^{\circ}$ \\
\hline 5 & \begin{tabular}{|l|l|}
23 & 24 \\
\end{tabular} & 25 & 22 & 20 & 25 & 26 & \begin{tabular}{|l|l|}
24 & 24 \\
\end{tabular} & 25 & 24 & 25 & 27 & 26 & 24 & 24 & 20 & 21 & 2 & 16 & 16 & 20 & \begin{tabular}{l|l}
16 & 14
\end{tabular} & 10 & 15 & 12 & 10 & 15 & 7 & 10 & 10) & 8 & 5 & 8 & 8 \\
\hline 10 & \begin{tabular}{l|l|}
0 & 1 \\
\end{tabular} & 1 & 2 & 1 & 2 & 1 & 3 & 0 & 2 & 1 & 0 & 0 & 1 & 1 & 4 & 2 & 3 & 4 & 3 & 1 & 23 & 4 & 1 & 1 & 1 & 1 & 1 & 4 & 3 & 6 & 2 & $\mathrm{l}$ & 3 \\
\hline 15 & \begin{tabular}{l|l}
1 & 1
\end{tabular} & 1 & 0 & 2 & 0 & 0 & 0 & 0 & 1 & 1 & 0 & 1 & 1 & 1 & 2 & 0 & 0 & 1 & 3 & 1 & \begin{tabular}{l|l}
3 & 2
\end{tabular} & 1 & 3 & 2 & 4 & 1 & 4 & 1 & 2 & 1 & 1 & 0 & 2 \\
\hline 20 & \begin{tabular}{|l|l|}
1 & 0 \\
\end{tabular} & 0 & 2 & 0 & 0 & 0 & 0 & 2 & 1 & 0 & 0 & 1 & 0 & 1 & 1 & 3 & 1 & 3 & 1 & 2 & \begin{tabular}{l|l}
2 & 2
\end{tabular} & 3 & 1 & 1 & 2 & 0 & 2 & 3 & 3 & 2 & 3 & 3 & 2 \\
\hline 25 & \begin{tabular}{l|l|}
1 & 2
\end{tabular} & 0 & 1 & 0 & 1 & 1 & 0 & 0 & 0 & 0 & 0 & 1 & 2 & 0 & 1 & 2 & 0 & 1 & 1 & 1 & 214 & 2 & 0 & 4 & 0 & 1 & 2 & 2 & 1 & 2 & 5 & 2 & 0 \\
\hline 30 & \begin{tabular}{l|l}
1 & 0
\end{tabular} & 1 & 0 & 2 & 1 & 0 & 0 & 1 & 0 & 1 & 0 & 0 & 1 & 1 & 0 & 0 & 0 & 0 & 1 & 1 & 2 & 4 & 3 & 2 & 1 & 2 & 1 & 4 & 2 & 0 & 2 & 1 & 4 \\
\hline 35 & \begin{tabular}{l|l}
1 & 0
\end{tabular} & 0 & 1 & 0 & 0 & 0 & 1 & 0 & 1 & 0 & 0 & 1 & 0 & 2 & 0 & 0 & 2 & 0 & 1 & 1 & 1 & 0 & 1 & 2 & 0 & 1 & 1 & 0 & 2 & 1 & 3 & 2 & 0 \\
\hline 40 & 0 & 1 & 0 & 2 & 1 & 0 & 0 & 0 & 0 & 0 & 0 & & 0 & & 0 & 1 & 1 & 3 & 0 & 0 & 0 & 2 & 1 & 1 & 5 & 0 & 1 & 2 & 1 & 1 & 0 & 2 & 3 \\
\hline 45 & \begin{tabular}{l|l|}
1 & 2 \\
\end{tabular} & 0 & 0 & 1 & & 1 & 0 & 1 & 0 & 1 & 2 & & 0 & & 0 & 0 & 0 & 0 & 1 & 1 & 0 & 0 & 0 & 1 & 4 & 2 & 3 & 0 & 0 & 1 & 3 & 0 & 0 \\
\hline 50 & 1 & 0 & 2 & 0 & & 0 & 0 & 0 & 1 & 0 & 0 & & 0 & & 1 & 1 & 0 & 1 & 1 & 0 & 0 & 1 & 1 & 0 & 1 & 3 & 0 & 1 & 2 & 1 & 0 & 3 & 1 \\
\hline 55 & & 1 & & 1 & & 0 & 0 & 1 & & 0 & 1 & & 0 & & 0 & & 1 & 0 & 0 & 0 & 21 & 2 & 1 & 0 & 0 & 2 & 1 & 2 & 1 & 0 & 0 & 0 & 2 \\
\hline 60 & & & & 0 & & 0 & 0 & & & 0 & & & 0 & & 0 & & & 0 & 11 & 1 & & 1 & 1 & 0 & 0 & 0 & 2 & 1 & 1 & 1 & 0 & 0 & 2 \\
\hline 65 & & & & 0 & & 0 & 0 & & & 1 & & & 0 & & 0 & & & 0 & 0 & 0 & & & 0 & 2 & 1 & 1 & 1 & 0 & 1 & 0 & 2 & 4 & 1 \\
\hline 70 & & & & 0 & & 0 & 0 & & & & & & 0 & & 0 & & & 1 & 0 & 0 & & & 1 & 0 & 0 & 0 & 0 & 0 & 0 & 1 & 1 & 1 & 0 \\
\hline 75 & & & & 1 & & 0 & 0 & & & & & & 1 & & 0 & & & & 0 & 0 & & & 0 & 1 & 1 & 0 & 2 & 0 & 0 & 1 & 1 & 0 & 0 \\
\hline 80 & & & & & & 0 & 0 & & & & & & & & 0 & & & & 0 & 0 & & & 0 & 0 & & 1 & 2 & 0 & 1 & 2 & 0 & 0 & 1 \\
\hline 85 & & & & & & 0 & 0 & & & & & & & & 0 & & & & 1 & 0 & & & 1 & 0 & & & & 0 & & 0 & 0 & 0 & 0 \\
\hline 90 & & & & & & 0 & 1 & & & & & & & & 0 & & & & & 0 & & & & 0 & & & & 0 & & 1 & 0 & 0 & 0 \\
\hline 95 & & & & & & 0 & & & & & & & & & 0 & & & & & 0 & & & & 0 & & & & 0 & & 0 & 0 & 0 & 0 \\
\hline 100 & & & & & & 0 & & & & & & & & & 0 & & & & & 0 & & & & 0 & & & & 0 & & $\overline{0}$ & 0 & 0 & 0 \\
\hline 105 & & & & & & 1 & & & & & & & & & 0 & & & & & 0 & & & & 1 & & & & 0 & & 0 & 0 & 0 & 0 \\
\hline 110 & & & & & & & & & & & & & & & 1 & & & & & 1 & & & & & & & & 0 & & 11 & 1 & 0 & $\overline{0}$ \\
\hline 115 & & & & & & & & & & & & & & & & & & & & & & & & & & & & 0 & & & 0 & 0 & 0 \\
\hline 120 & & & & & & & & & & & & & & & & & & & & & & & & & & & & 0 & & & 0 & 1 & 1 \\
\hline 125 & & & & & & & & & & & & & & & & & & & & & & & & & & & & 0 & & & 0 & 1 & \\
\hline 130 & & & & & & & & & & & & & & & & & & & & & & & & & & & & & & & 0 & 0 & \\
\hline 135 & & & & & & & & & & & & & & & & & & & & & & & & & & & & & & & 0 & 0 & \\
\hline 140 & & & & & & & & & & & & & & & & & & & & & & & & & & & & & & & 1 & 0 & \\
\hline 145 & & & & & & & & & & & & & & & & & & & & & & & & & & & & & & & & 0 & \\
\hline 150 & & & & & & & & & & & & & & & & & & & & & & & & & & & & & & & & 0 & \\
\hline 155 & & & & & & & & & & & & & & & & & & & & & & & & & & & & & & & & 1 & \\
\hline
\end{tabular}


ANEXO D - Balanço Hidrico Normal

- ZAi : Jardinopolis

\begin{tabular}{|c|c|c|c|c|c|c|c|c|c|}
\hline AES & $T$ & $E P$ & $P$ & $P-E P$ & ARMI & $\bar{A} \bar{I}$ & $\bar{\Sigma} \bar{\kappa}$ & $\bar{\nu} \bar{E} \bar{F}$ & $E A L$ \\
\hline 1 & 24.7 & 127 & 257 & 130 & 100 & 0 & 127 & u & 130 \\
\hline 2 & 24.8 & 112 & 225 & 113 & 100 & a & \pm 2 & $\simeq$ & $\pm \geq 2$ \\
\hline 3 & 24.4 & 113 & 169 & 55 & 100 & 0 & 113 & 0 & 55 \\
\hline 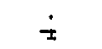 & 22.6 & 85 & 111 & 26 & 100 & 0 & 85 & 0 & 26 \\
\hline 5 & 20.4 & 53 & $6 \epsilon$ & 2 & 100 & 0 & 63 & 0 & 2 \\
\hline 6 & 19.3 & 52 & 25 & -27 & 76 & -24 & 49 & 3 & 0 \\
\hline 7 & 19.2 & 53 & 28 & $-\Xi 5$ & 59 & -13 & 45 & 3 & 0 \\
\hline$\because$ & $\therefore \quad$ & 73 & 34 & $-\therefore a$ & 35 & -23 & 17 & 25 & $n$ \\
\hline 9 & 22.9 & 90 & 77 & -14 & 31 & -5 & 82 & 8 & 0 \\
\hline 10 & 23.8 & 109 & 157 & 48 & 80 & 46 & 200 & $\therefore$ & 0 \\
\hline$\therefore$ & $2 \div$ & 122 & 185 & 73 & 100 & 10 & $\pm=2$ & 0 & 53 \\
\hline$i 2$ & 742 & 123 & $2 n a$ & 186 & 100 & 0 & 123 & 0 & 186 \\
\hline & $? 2$ & 1118 & 1640 & 521 & & 0 & 1072 & $40^{\circ}$ & 507 \\
\hline
\end{tabular}

LOCAL :CLUBE DE REGATAS

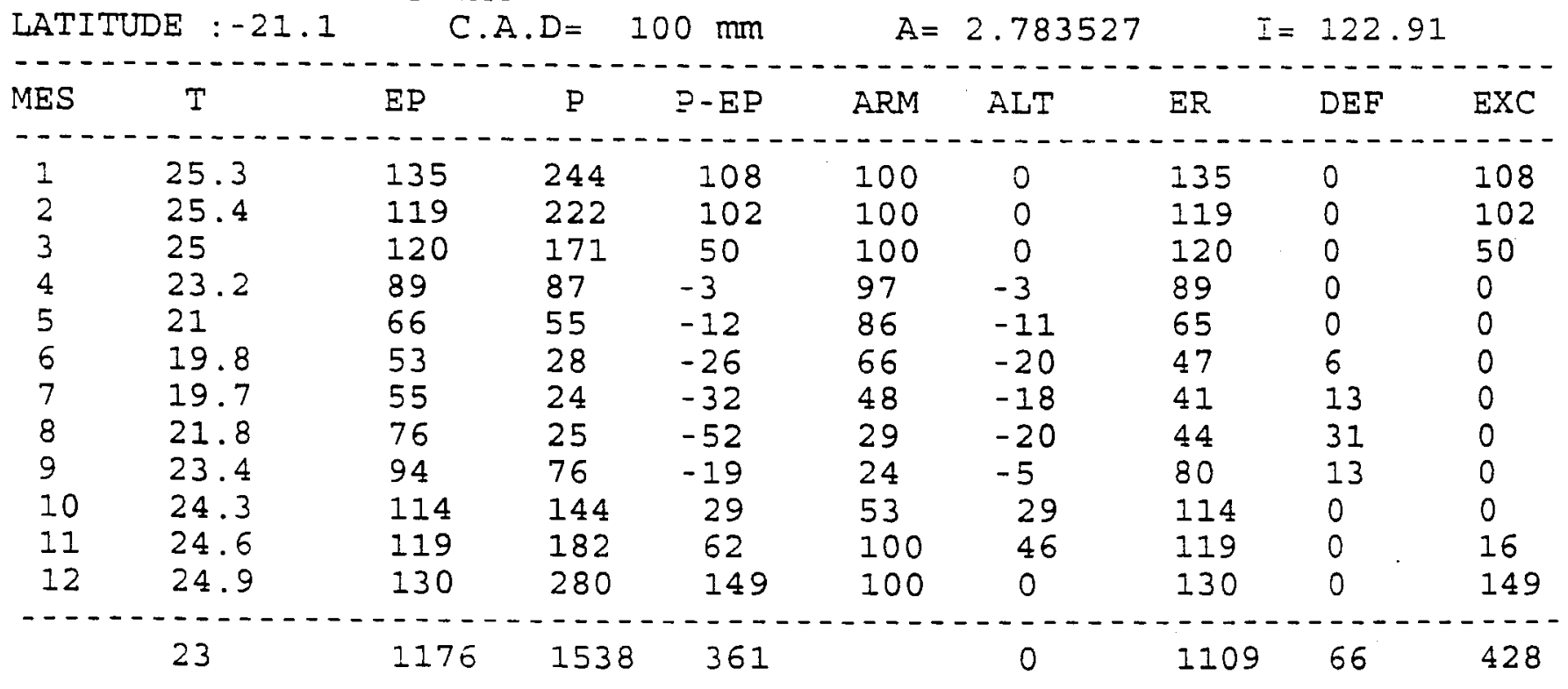


ANEXO D - Balanço Hídrico Normal (continuação)

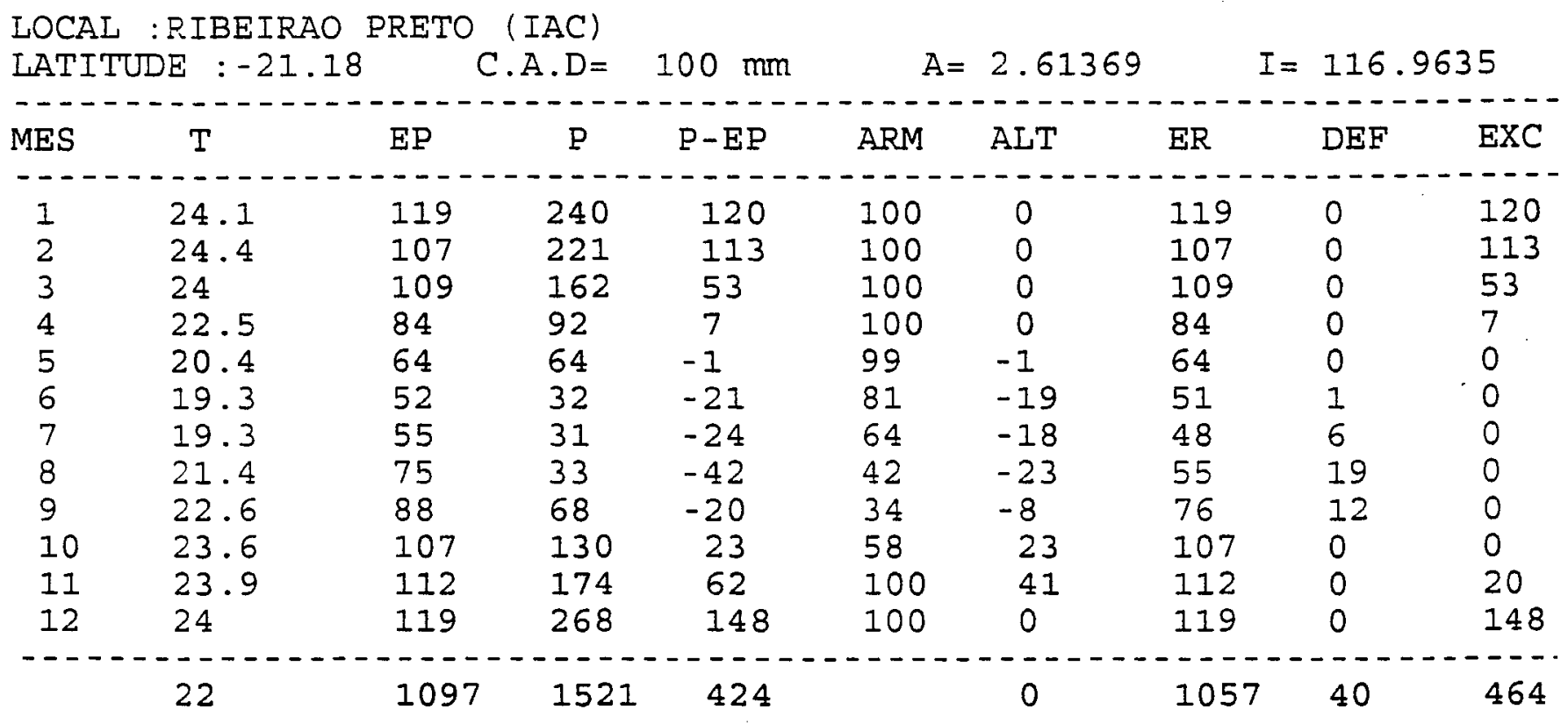

LOCAL :RIBEIRAO-1

LATITUDE : -21.22

C.A.D $=100 \mathrm{~mm} \quad A=2.633757$

$I=117.6879$

$-$

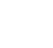

1

11$$
\text { - }
$$

$\mathrm{T}$

\section{7}

24.8

24.4

22.5

20.3

19.2

19.1

21.1

22.7

$10 \quad 23.6$

$11 \quad 23.9$

$12 \quad 24.2$

22
EP

127

112

113

84

63

51

53

72

89

107

111

122

P P-EP

\section{3}

222

152

84

52

31

23

26

64

134

175

274

\section{5}

109

38

$-1$

$-12$

$-21$

$-31$

$-47$

$-26$

26

63

151
ARM

ALT

\section{0}

100

100

99

88

72

53

33

26

53

100

100
ER

127

112

113

84

62

47

41

45

71

107

111

122
DEF

EXC

115

109

38

0

0

0

0

0

0

0

16

151

$1109 \quad 1480 \quad 370 \quad 004060$


ANEXO D - Balanço Hídrico Normal (continuação)

LOCAL : CRAVINHOS

LATITUDE : -21.36

C.A.D $=100 \mathrm{~mm}$

$A=2.448099$

$I=110.7428$

MES

$T$

EP

P P-EP

ARM ALT

ER

$\mathrm{DEF}$

EXC

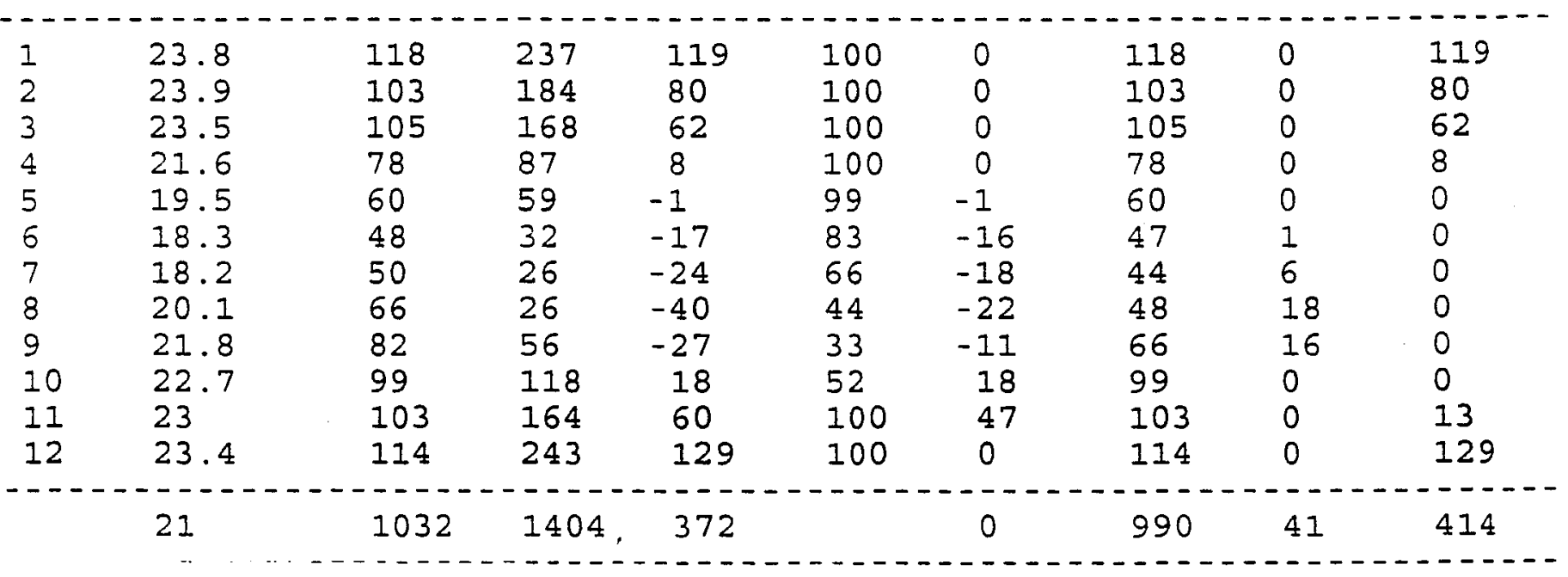

LOCAL : CAPAO DA CRUZ

LATITUDE : -21.45

C.A.D $=100 \mathrm{~mm}$

$A=2.603283$

$I=116.5854$

MES

EP

P P-EP

ARM ALT

ER

DEF

EXC

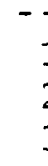

3
2
3
4
5
6
7

24.6

24.7

126

24.3

22.4

20.2

19

111

249

122

204

92

112

166

53

83

62

83

$-1$

52

$-11$

27

$-24$

52

25

$-28$

70

26

$-45$

87

69

$-19$

105

121

111

163

15

51

121

259

137

100

100

100

99

88

70

53

34

28

44

95

100

0

0

0

$-1$

$-11$

$-19$

$-17$

$-20$

$-6$

15

51

4
126

111

112

83

62

45

41

45

74

105

111

121
0

0

0

0

0

4

10

25

12

0

0

0

- -

104254

401
122

92

53

0

0

0

0

0

0

0

0

133

$$
22
$$

1097

$1444 \quad 346$

0 
ANEXO D - Balanço Hidrico Normal (continuação)

LOCAL : EAZ. STA. CLARA

LATITUDE :-21.42 C.A.D $=100 \mathrm{~mm} \quad A=2.41566 \quad I=109.4703$

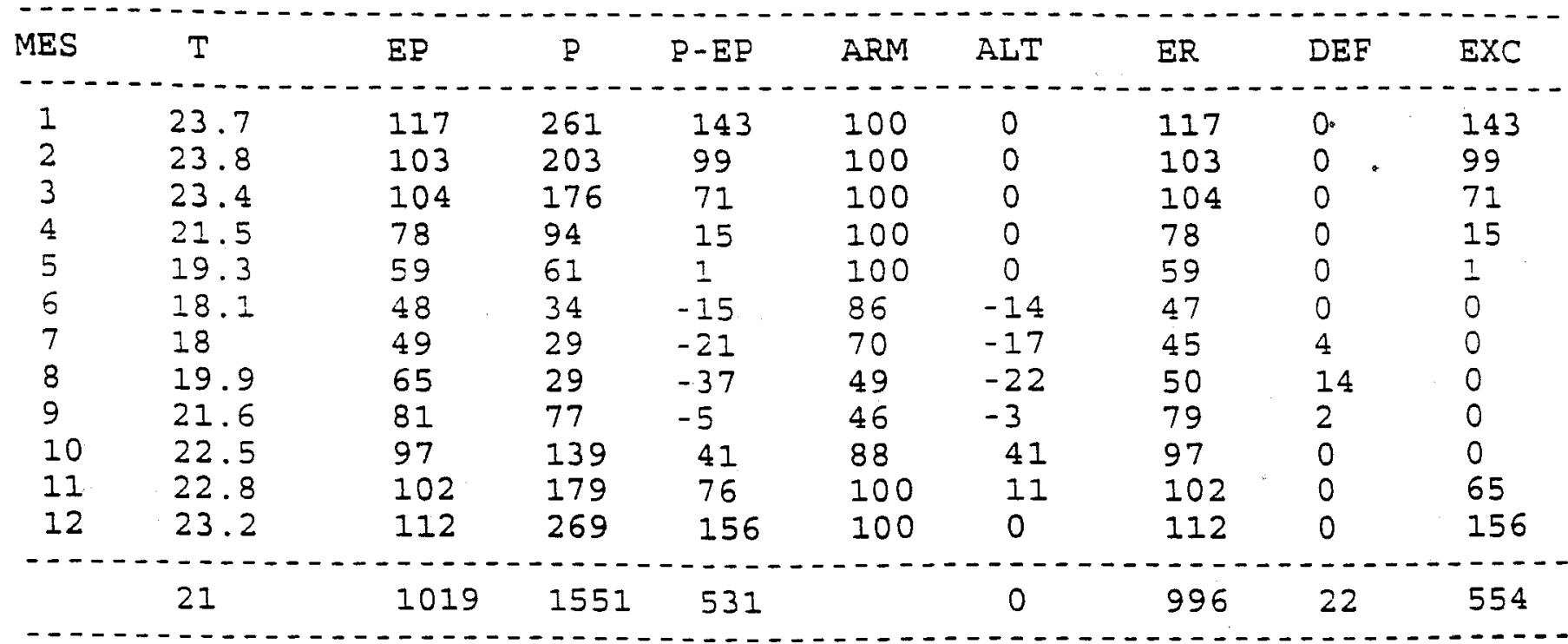

LOCAL : SAO SIMAO

LATITUDE :-2I.48

C.A.D $=100 \mathrm{~mm} \quad \quad \dot{s}=2.458801 \quad I=211.2586$

\begin{tabular}{|c|c|c|c|c|c|c|c|c|c|}
\hline MES & $I$ & $E P$ & P & $P-E P$ & ARM & $A L T$ & ER & $D E F$ & EXC \\
\hline $\begin{array}{l}1 \\
2 \\
3 \\
4 \\
5 \\
6 \\
7 \\
8 \\
9 \\
10 \\
11 \\
12\end{array}$ & $\begin{array}{l}23.8 \\
24 \\
23.5 \\
22.1 \\
19.6 \\
17.6 \\
17.8 \\
20.1 \\
21.5 \\
23.1 \\
23.6 \\
23.6\end{array}$ & $\begin{array}{l}118 \\
104 \\
105 \\
82 \\
60 \\
44 \\
47 \\
66 \\
79 \\
103 \\
110 \\
116\end{array}$ & $\begin{array}{l}245 \\
172 \\
155 \\
84 \\
77 \\
31 \\
27 \\
28 \\
69 \\
127 \\
182 \\
264\end{array}$ & $\begin{array}{l}127 \\
67 \\
50 \\
1 \\
16 \\
-14 \\
-20 \\
-39 \\
-11 \\
24 \\
72 \\
147\end{array}$ & $\begin{array}{l}100 \\
100 \\
100 \\
100 \\
100 \\
87 \\
72 \\
49 \\
44 \\
68 \\
100 \\
100\end{array}$ & $\begin{array}{c}0 \\
0 \\
0 \\
0 \\
0 \\
-13 \\
-16 \\
-23 \\
-5 \\
24 \\
31 \\
0\end{array}$ & $\begin{array}{l}118 \\
104 \\
105 \\
82 \\
60 \\
43 \\
43 \\
51 \\
74 \\
103 \\
110 \\
116\end{array}$ & $\begin{array}{l}0 \\
0 \\
0 \\
0 \\
0 \\
0 \\
4 \\
15 \\
5 \\
0 \\
0 \\
0\end{array}$ & $\begin{array}{l}127 \\
67 \\
50 \\
1 \\
16 \\
0 \\
0 \\
0 \\
0 \\
0 \\
40 \\
147\end{array}$ \\
\hline & 21 & 1040 & 1466 & 426 & & 0 & 1014 & 25 & 451 \\
\hline
\end{tabular}


ANEXO D - Balanço Hídrico Normal (continuação)

LOCAL : PRAINHA DC TAMANDUA

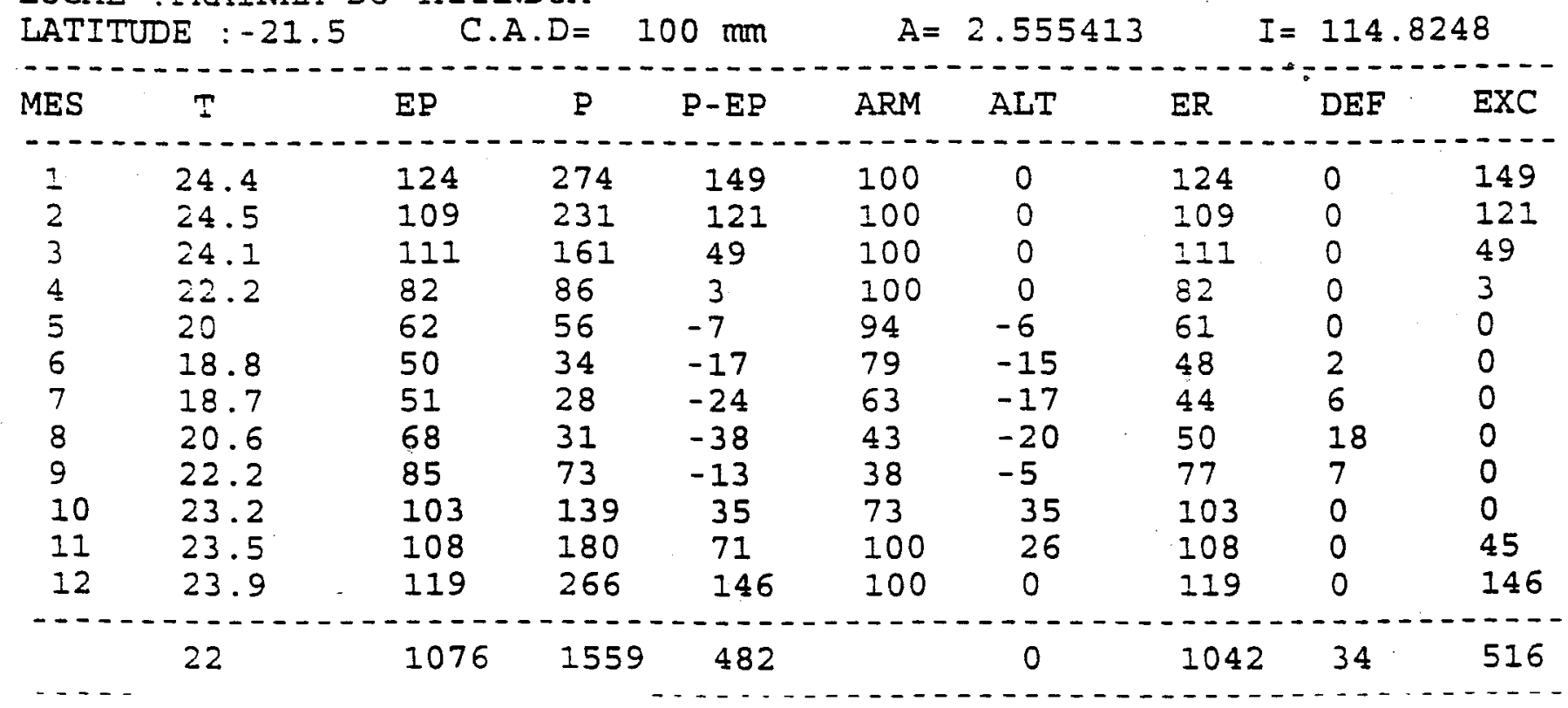

